\title{
Sociocultural and ecological factors influencing management of edible and non-edible plants: the case of Ixcatlán, Mexico
}

\author{
Selene Rangel-Landa ${ }^{1}$, Alejandro Casas ${ }^{1 *}$, Eduardo García-Frapolli ${ }^{1}$ and Rafael Lira²
}

\begin{abstract}
Background: Identifying factors influencing plant management allows understanding how processes of domestication operate. Uncertain availability of resources is a main motivation for managing edible plants, but little is known about management motives of non-edible resources like medicinal and ceremonial plants. We hypothesized that uncertain availability of resources would be a general factor motivating their management, but other motives could operate simultaneously. Uncertainty and risk might be less important motives in medicinal than in edible plants, while for ceremonial plants, symbolic and spiritual values would be more relevant.
\end{abstract}

Methods: We inventoried edible, medicinal, and ceremonial plants in Ixcatlán, Oaxaca, Mexico, and conducted in-depth studies with 20 native and naturalized species per use type; we documented their cultural importance and abundance by interviewing 25 households and sampling vegetation in 33 sites. Consumption amounts and preferences were studied through surveys and free listings with 38 interviewees. Management intensity and risk indexes were calculated through PCA and their relation analyzed through regression analyses. Canonical methods allowed identifying the main sociocultural and ecological factors influencing management of plants per use type.

Results: Nearly 64,63 , and $55 \%$ of all ceremonial, edible, and medicinal wild plants recorded, respectively, are managed in order to maintain or increase their availability, embellishing environments, and because of ethical reasons and curiosity. Management intensity was higher in edible plants under human selection and associated with risk. Management of ceremonial and medicinal plants was not associated with indexes of risk or uncertainty in their availability. Other sociocultural and ecological factors influence management intensity, the most important being reciprocal relations and abundance perception.

Conclusions: Plant management through practices and collectively regulated strategies is strongly related to control of risk and uncertainty in edible plants, compared with medicinal and ceremonial plants, in which reciprocal interchanges, curiosity, and spiritual values are more important factors. Understanding how needs, worries, social relations, and ethical values influence management decisions is important to understand processes of constructing management strategies and how domestication could be started in the past and are operated at the present.

Keywords: Cultural importance, Domestication, Ixcatec, Plant management, Risk management, Reciprocity interchange, Spiritual values and plant management, Tehuacán Valley

\footnotetext{
* Correspondence: acasas@cieco.unam.mx

${ }^{1}$ Instituto de Investigaciones en Ecosistemas y Sustentabilidad, UNAM,

Antigua Carretera a Pátzcuaro 8711, 58190 Morelia, Michoacán, Mexico

Full list of author information is available at the end of the article
} 


\section{Background}

Management of plant resources and traditional ecological knowledge (TEK) are intimately related biocultural aspects that crucially influence the modeling of strategies of multiple use of natural resources in rural communities [1-3]. Understanding how management systems do operate, and identifying the factors influencing and motivating them, is greatly important for analyzing how and why plant management is currently decided, how the ongoing processes of domestication are operating, and how these could have operated in the past [4]. Therefore, studies of these processes may be relevant for designing current strategies of sustainable use of plant resources and ecosystems, as well as for understanding factors that led humans to start domestication and agriculture in the past.

Management can be defined as all practices, interventions, transformations, strategies, or decisions deliberately made by humans on ecosystems, their components, functions, and even their emergent properties, in order to use, conserve, or recover them $[5,6]$. In traditional contexts, management practices are based on ancient knowledge transmitted from generation to generation, but innovations are continually constructed influenced by new observations, experimentation, and information from recent sources (information from neighboring villages, schools, communication media, interventions by NGOs, governmental promoters, researchers, among others). Both old and new management practices are organized in dynamic systems of knowledge, beliefs, cultural and spiritual values, and local institutions $[7,8]$.

For studying domestication, it is particularly interesting to document the morphological and genetic divergences between wild and managed populations directed to maintain or increase the availability of particular phenotypes of managed species. Such aspects provide valuable elements for explaining how processes of domestication currently operate and how these could have operated in the past. The ongoing processes of domestication can be documented in numerous rural communities of the world and are responsible for a continuous mechanism of divergence and generation of a new variation of genetic resources. As a research group, we have focused our attention on domestication processes occurring in Mesoamerica, one of the most active areas of plant management and one of the earliest centers of plant domestication in the World $[5,9,10]$. Numerous studies have documented the consequences of domestication, but relatively few have analyzed what factors motivate people to manage and domesticate plants, animals, and other organisms. In this study, we focus our attention to analyzing the main causes of the process.

Management involves several types of practices, tools, and relations between energy invested and amounts of resources obtained; such aspects reflect different degrees of management intensity $[11,12]$. Authors analyzing this topic coincide that management intensity of plants goes from gathering, let standing, special care, protection, and transplanting, to practices procuring increase of desirable plant abundance by enhancing and deliberately propagating them $[5,6]$. Some variables have been proposed as relevant for analyzing the degree of management intensity: (1) the number and complexity of practices carried out, (2) the number of people or social units (i.e., persons, households, or communities) participating in such practices, (3) the involvement and level of complexity of planning strategies, (4) social agreements regulating the actions, (5) the occurrence of human selection favoring particular phenotypes and the intensity in which it operates, (6) the deliberate practices favoring human-mediated gene flow and manipulation of plant reproduction, (7) the amounts of fossil or human energy invested in practices, (8) the complexity of tools used, and (9) the amount of products obtained per area unit [11-13].

In several case studies with cacti, agaves, herbs, and trees, mainly with edible use, we have documented that managed plants under higher management intensity are those more consumed or commercialized and whose future availability becomes compromised due to their relatively low availability in relation to the demand on them [11-17]. In other words, plant management is influenced by the amounts of products required by social units (which is in turn influenced by their cultural and economic value) but also by people's perception of the product quality and their substitutability or not by other resources. In addition, management is influenced by the natural availability of plant products, determined by parameters like distribution and abundance, their resilience capacity after human impact on populations, their vulnerability, and management feasibility $[11,12,18]$, as well as the ease of access to resources regulated by land tenure and communitarian agreements. All these relations have allowed proposing that management is a response to the need of facing risks or uncertainty in the current and future availability of resources [12]. In other words, it is a response of people's worries for ensuring availability of resources $[12,19]$ or preventing their loss [15].

However, some studies have documented that cultural motives such as relations of reciprocity among persons and communities, some spiritual aspects, and efforts to maintain customs and traditions [20,21] commonly motivate management practices. In addition, practices such as tolerance or let standing of plants in disturbed areas may be associated with ethical principles like the right of plants to live, whereas enhancing abundance of some species may be associated to favor variants of higher quality to embellish the sites where they occur [22-26]. Transplanting and other forms of propagation may 
simply be motivated by the need to have particular plants closer because of their beauty, odor, and role in rituals or simply because of curiosity to know how plants grow and reproduce $[19,23]$. These scenarios allow supposing that management type and intensity are not only responses to risk, but also practices related to ethic or esthetic values, symbolism, or curiosity, and all factors may be operating simultaneously. Analyzing how people make management decisions on plants with different purposes may allow visualizing more clearly different motives for managing plants and management intensity [12, 27]. Therefore, this study explores management motives for plants with different use types.

We hypothesized that uncertainty in availability of plant resources is a main factor motivating management of plants, especially those directed to satisfy basic needs. We therefore expected that edible plants would have higher management intensity as the higher the risk or uncertainty in their availability, as similarly documented in previous studies $[12,13]$. Uncertainty would be influenced by the scarcity of plant resources and human pressures on them; therefore, scarce species with high cultural value would be more intensely managed. Ecological aspects of plants like survival, vigor, or resprouting capacities, which may be affected by use, and others that influence the ease of management like life cycle length, reproductive systems, ease of propagation, and adaptability to human-made environments would influence management types and intensities. Medicinal plants are generally used in smaller amounts than edible plants (except those that are extracted for commercialization); therefore, we expected that the pattern of management as a response to risk would be less pronounced than in edible plants [12]. Finally, we expected that the management of plants used for rituals and ceremonies, is not necessarily influenced by risk since purposes and amounts of plants used for these purposes follow different rationalities in which reciprocity relations, esthetic and symbolic values could be important.

Summarizing, our study aimed to analyze how management type and intensity are influenced by sociocultural and ecological factors in edible, medicinal, and ceremonial plants among the Ixcatec from Santa María Ixcatlán, Mexico. We analyzed whether or not people's worries about availability of plants operate similarly in plants with different use type and look for evaluating the weight of different motives for decisions on managing plant resources.

\section{Methods \\ Study area}

Santa María Ixcatlán belongs to the Tehuacán-Cuicatlán Biosphere Reserve, Central México (Fig. 1). It is located at elevations from 800 to $2600 \mathrm{~m}$, with annual rainfall of $721 \mathrm{~mm}$ and average temperature of $17.2^{\circ} \mathrm{C}$. Climate is temperate sub-humid in high zones and semiarid in lowlands [28, 29]. The traditional General Assembly regulates decisions on land, natural resources, and social life [30]. Ixcatlán is inhabited by 171 households [31], almost all of them catholic [26]; $80 \%$ of the people

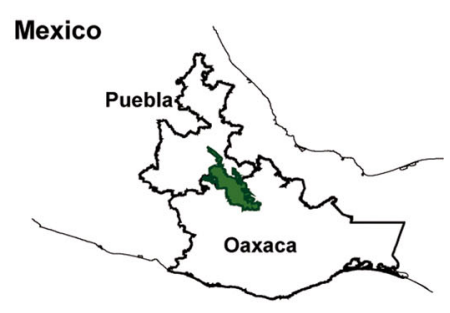

Tehuacán-Cuicatlán Biosphere Reserve

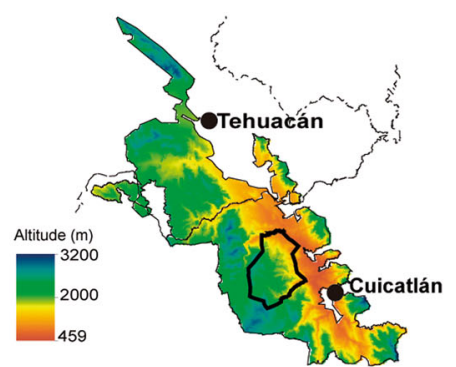

Information: DEM, national and regional polygons (INEGI 2000, 2001, 2010 accesed 2015). Ixcatlán polygon (DOF1948 [34], INEGI-RAM accesed 2015). Satelital image (Google Satellite accesed 14 May 2016).

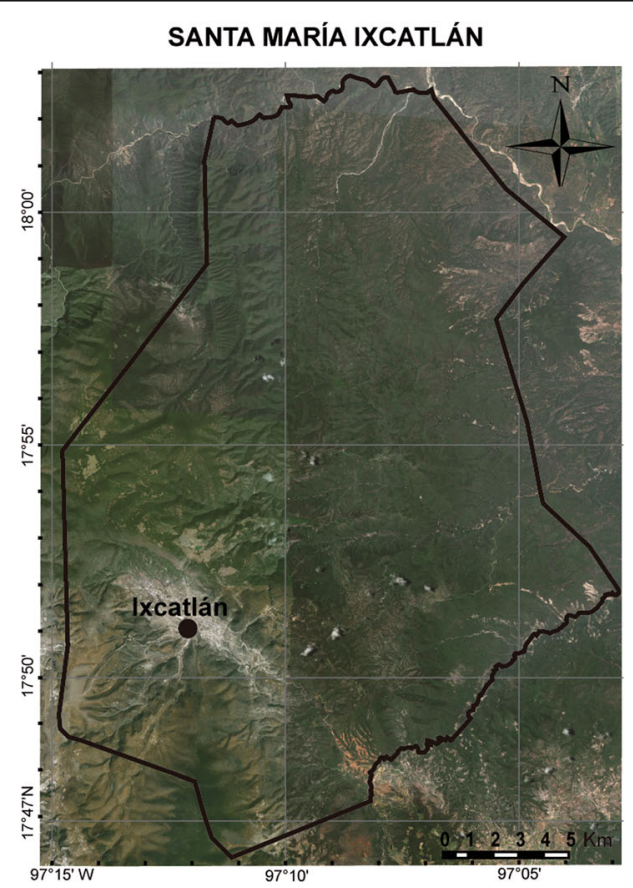

Fig. 1 Location of the community of Santa María Ixcatlán, Oaxaca, Central México 
consider themselves to be indigenous, but only 15 persons speak Ixcatec, and this is the only village of the world where the Ixcatec language is spoken [31, 32]. Subsistence of the people is based on the multiple use of natural resources and ecosystems, seasonal agriculture, livestock raising, and forest resource extraction [26]. We previously reported 630 plant species used by local people for satisfying different needs [26], nearly 400 species receiving some type of management in order to increase their abundance [26]. Gathering and management of plants is carried out in 18 types of forests, agroforestry systems, and homegardens over a 41,530-ha territory [26, 31-35].

\section{Inventory of edible, medicinal, and ceremonial plants}

Ethnobotanical studies by Rangel-Landa et al. [26] documented names, uses, and management of all plant species through semi-structured interviews with 44 persons (see Table 1) in 73 sessions. The information was systematized into the ethnobotanical database of Mexican plants (BADEPLAM), at the Botanical Garden, UNAM, and voucher specimens were deposited in the herbaria MEXU, EBUM, IEB-Bajío, and IBUG. The nomenclature of plant species followed APG III consulted through the site www.theplantlist.org [36].

\section{In-depth interviews and surveys}

In order to analyze how management is influenced by sociocultural and ecological factors, we selected samples of edible, medicinal, and ceremonial plants. The samples included 20 species of native and naturalized plants per use type, representing the management intensity gradient [26].

In-depth interviews were conducted to obtain deeper and detailed information on uses, values, perception about availability, vulnerability, and management practices (Table 2) for the selected species. These interviews were conducted with 25 persons selected at random (17 women and 8 men, see Table 1). In order to estimate the proportion of families that consume the studied plants in the village, we conducted a survey documenting the role of plant resources in people subsistence [26]. The survey included 20 households selected at random.

\section{Free listing}

For exploring the use preferences of the plants studied, we included different valuing criteria (utilitarian, symbolic, esthetic, and emotional) through the free listing technique [37, 38]. We interviewed 38 persons ( 22 men, 16 women, Table 1) [26], asking them to list plants used: (1) in ceremonies and offerings to Saints and dead people, (2) as food, (3) for health care [26], and (4) for satisfying basic needs, those considered indispensable to live. We estimated their cognitive prominence for each use type through the formula $S=F /(N \mathrm{mP})$, where $F$ is the frequency of each plant species, $N$ the number of people interviewed, and $\mathrm{mP}$ the average position in which a plant was named [39]. The index was calculated with Flame v1.0 [40].

\section{Vegetation sampling}

In order to identify the places where the plant species studied are managed, and how abundant they are in forests and agroforestry systems (AFS), we sampled vegetation in 7 agricultural plots, 21 homegardens, and 5 AFS associated to sites of mescal production [26].

\section{Selection of variables for the analyses}

Socio-ecological and technological variables were selected based on our previous studies [11, 12], which were organized in three main data matrixes. One matrix was with information on indicators of social, cultural, and economic importance of the species studied. A second matrix had information on biological aspects (life cycle length, types of reproduction, growth patterns, among others) and on people's perception about the availability and vulnerability of each species. The third matrix had information about management practices and management intensity. Information on qualitative variables were categorized assigning numeric values from lower to higher management intensity according to the complexity of strategies and practices, occurrence or not of human selection, and low to high number of persons involved in the management type, among others. We also categorized from lower to higher social, cultural, and economic importance, considering that the higher their importance, the higher the potential risk associated to human pressure. Finally, we categorized from lower to higher vulnerability associated with biological characters considering the impact of human extraction of resources on individual plants and populations (Table 2). We averaged values of different categories, and in variables involving counting or binary records, we calculated the proportions of the states (Table 2). We excluded highly correlated variables, selecting those better representing the importance and management intensity of the plant species analyzed (Table 2).

\section{Data analyses}

In order to characterize the use and management of plants with edible, medicinal, and ceremonial uses, we used our previous data about all the species recorded [26] and the in-depth interviews for the selected species. We analyzed these data by cross-checking information and using descriptive statistics. We conducted principal component analysis (PCA) with data about management of all the native and naturalized species in order to classify management intensity among use types. The scores of the first principal component were used as management intensity 
Table 1 Consultants' details and the activities in which they collaborated

\begin{tabular}{|c|c|c|c|c|c|c|c|c|c|c|c|c|}
\hline ID & Sex & Age & Language & Main activities & $\begin{array}{l}\text { Participant } \\
\text { type }\end{array}$ & $\begin{array}{l}\text { Semiestructured } \\
\text { interviews }\end{array}$ & $\begin{array}{l}\text { Free } \\
\text { lists }\end{array}$ & $\begin{array}{l}\text { Surveys } \\
2012\end{array}$ & $\begin{array}{l}\text { In-depth } \\
\text { interviews }\end{array}$ & Homegarden & $\begin{array}{l}\text { Agricultural } \\
\text { field }\end{array}$ & $\begin{array}{l}\text { Mescal } \\
\text { factory }\end{array}$ \\
\hline 1 & Male & 25 & Spanish & Mescal production & $\begin{array}{l}\text { Key } \\
\text { participant }\end{array}$ & Yes & Yes & & & & & 2 \\
\hline 2 & Male & 50 & Spanish & $\begin{array}{l}\text { Agriculture, mescal } \\
\text { production }\end{array}$ & $\begin{array}{l}\text { Key } \\
\text { participant }\end{array}$ & Yes & & 16 & & & 1 & \\
\hline 3 & Male & 72 & $\begin{array}{l}\text { Spanish, } \\
\text { Ixcatec }\end{array}$ & Agriculture, palm weaver & & & & & & & 6 & \\
\hline 4 & Male & 66 & Spanish & Agriculture, palm weaver & & & & 12 & & & & \\
\hline 5 & Male & 46 & Spanish & Agriculture, palm weaver & $\begin{array}{l}\text { Key } \\
\text { participant }\end{array}$ & Yes & Yes & & & & 2 & \\
\hline 6 & Female & 44 & Spanish & $\begin{array}{l}\text { Domestic chores, palm } \\
\text { weaver }\end{array}$ & & Yes & & 15 & & 8 & & \\
\hline 9 & Male & & Spanish & Agriculture, palm weaver & & Yes & & & & 5 & & \\
\hline 10 & Male & 48 & Spanish & Agriculture, commerce & $\begin{array}{l}\text { Key } \\
\text { participant }\end{array}$ & Yes & Yes & 1 & & & & \\
\hline 11 & Male & 62 & Spanish & $\begin{array}{l}\text { Agriculture, mescal } \\
\text { production }\end{array}$ & $\begin{array}{l}\text { Key } \\
\text { participant }\end{array}$ & Yes & & & & 10 & & \\
\hline 12 & Male & 35 & Spanish & $\begin{array}{l}\text { Agriculture, mescal } \\
\text { production, palm weaver }\end{array}$ & & & & 13 & & & & \\
\hline 14 & Male & 67 & Spanish & Agriculture, palm weaver & & & & & & & 3 & \\
\hline 16 & Male & 73 & Spanish & $\begin{array}{l}\text { Agriculture, mescal } \\
\text { production, palm weaver }\end{array}$ & & & Yes & & & & & \\
\hline 17 & Female & & Spanish & Student & & & Yes & & & & & \\
\hline 18 & Female & 60 & Spanish & $\begin{array}{l}\text { Domestic chores, palm } \\
\text { weaver }\end{array}$ & & Yes & & & & 13 & & \\
\hline 19 & Female & 35 & Spanish & $\begin{array}{l}\text { Domestic chores, palm } \\
\text { weaver }\end{array}$ & & & & 1 & & & & \\
\hline 20 & Female & 62 & Spanish & $\begin{array}{l}\text { Domestic chores, palm } \\
\text { weaver }\end{array}$ & $\begin{array}{l}\text { Key } \\
\text { participant }\end{array}$ & Yes & & 7 & Yes & 15 & & \\
\hline 23 & Male & 72 & Spanish & Agriculture, palm weaver & & & Yes & & & 3 & & \\
\hline 24 & Male & 70 & Spanish & Agriculture, palm weaver & & & & 14 & & & & \\
\hline 25 & Male & 51 & Spanish & $\begin{array}{l}\text { Agriculture, mescal } \\
\text { production, palm weaver }\end{array}$ & & & & 5 & & & & \\
\hline 26 & Male & 82 & $\begin{array}{l}\text { Spanish, } \\
\text { Ixcatec }\end{array}$ & Agriculture, palm weaver & $\begin{array}{l}\text { Key } \\
\text { participant }\end{array}$ & Yes & & & & & 4 & \\
\hline 27 & Male & & Spanish & Agriculture, palm weaver & & & & 6 & & & & \\
\hline 28 & Male & 68 & Spanish & Agriculture, palm weaver & & & & 4 & & & & \\
\hline 30 & Male & 59 & Spanish & $\begin{array}{l}\text { Agriculture, mescal } \\
\text { production, palm weaver }\end{array}$ & & & Yes & & & & & \\
\hline 31 & Male & 57 & Spanish & Shepherd & $\begin{array}{l}\text { Key } \\
\text { participant }\end{array}$ & Yes & Yes & & Yes & & & \\
\hline 34 & Female & 48 & Spanish & $\begin{array}{l}\text { Domestic chores, palm } \\
\text { weaver }\end{array}$ & & & & 5 & & & & \\
\hline 35 & Male & & Spanish & Student & & & Yes & & & & & \\
\hline 36 & Female & 70 & Spanish & $\begin{array}{l}\text { Domestic chores, palm } \\
\text { weaver }\end{array}$ & & Yes & & & & 7 & & \\
\hline 37 & Female & 46 & Spanish & Commerce, domestic chores & & & Yes & & Yes & & & \\
\hline 38 & Female & 18 & Spanish & Student & & Yes & & & & & & \\
\hline 39 & Female & & Spanish & $\begin{array}{l}\text { Domestic chores, palm } \\
\text { weaver }\end{array}$ & & & Yes & 20 & & & & \\
\hline 41 & Female & 34 & Spanish & Domestic chores, palm & & & Yes & & Yes & & & \\
\hline
\end{tabular}


Table 1 Consultants' details and the activities in which they collaborated (Continued)

\begin{tabular}{|c|c|c|c|c|c|c|c|c|c|c|c|c|}
\hline ID & Sex & Age & Language & Main activities & $\begin{array}{l}\text { Participant } \\
\text { type }\end{array}$ & $\begin{array}{l}\text { Semiestructured } \\
\text { interviews }\end{array}$ & $\begin{array}{l}\text { Free } \\
\text { lists }\end{array}$ & $\begin{array}{l}\text { Surveys } \\
2012\end{array}$ & $\begin{array}{l}\text { In-depth } \\
\text { interviews }\end{array}$ & Homegarden & $\begin{array}{l}\text { Agricultural } \\
\text { field }\end{array}$ & $\begin{array}{l}\text { Mescal } \\
\text { factory }\end{array}$ \\
\hline$\overline{42}$ & Female & 64 & $\begin{array}{l}\text { Spanish, } \\
\text { Ixcatec }\end{array}$ & $\begin{array}{l}\text { Domestic chores, palm } \\
\text { weaver }\end{array}$ & $\begin{array}{l}\text { Key } \\
\text { participant }\end{array}$ & Yes & Yes & 12 & & 17 & & \\
\hline 43 & Male & & Spanish & $\begin{array}{l}\text { Agriculture, mescal } \\
\text { production, palm weaver }\end{array}$ & & Yes & & & & & & \\
\hline 46 & Male & 54 & Spanish & Agriculture, palm weaver & & & & 15 & & & & \\
\hline 47 & Female & 41 & Spanish & $\begin{array}{l}\text { Domestic chores, palm } \\
\text { weaver }\end{array}$ & & & & & Yes & 10 & & \\
\hline 48 & Female & & Spanish & $\begin{array}{l}\text { Domestic chores, palm } \\
\text { weaver }\end{array}$ & & Yes & & & & 12 & & \\
\hline 49 & Male & & Spanish & Commerce & & Yes & & & & & & \\
\hline 50 & Female & 41 & Spanish & Commerce, domestic chores & & & Yes & & & & & \\
\hline 51 & Female & 35 & Spanish & $\begin{array}{l}\text { Domestic chores, palm } \\
\text { weaver }\end{array}$ & & & & 6 & & & & \\
\hline 52 & Male & 76 & $\begin{array}{l}\text { Spanish, } \\
\text { Ixcatec }\end{array}$ & Agriculture, palm weaver & $\begin{array}{l}\text { Key } \\
\text { participant }\end{array}$ & Yes & Yes & 9 & & 16 & & \\
\hline 53 & Male & & Spanish & Agriculture, palm weaver & & & & & & 12 & & \\
\hline 55 & Male & 32 & Spanish & $\begin{array}{l}\text { Agriculture, construction } \\
\text { worker, palm weaver }\end{array}$ & & & Yes & & & & & \\
\hline 57 & Female & & Spanish & $\begin{array}{l}\text { Domestic chores, palm } \\
\text { weaver }\end{array}$ & & Yes & & & & 9 & & \\
\hline 58 & Female & 41 & Spanish & $\begin{array}{l}\text { Domestic chores, palm } \\
\text { weaver }\end{array}$ & $\begin{array}{l}\text { Key } \\
\text { participant }\end{array}$ & Yes & Yes & 16 & & & & \\
\hline 59 & Male & 38 & Spanish & Agriculture, palm weaver & & & Yes & & & & & \\
\hline 60 & Female & 83 & Spanish & $\begin{array}{l}\text { Domestic chores, palm } \\
\text { weaver }\end{array}$ & & & & 11 & & & & \\
\hline 61 & Female & 88 & $\begin{array}{l}\text { Spanish, } \\
\text { Ixcatec }\end{array}$ & $\begin{array}{l}\text { Domestic chores, palm } \\
\text { weaver }\end{array}$ & & & & 2 & & & & \\
\hline 63 & Female & 59 & Spanish & $\begin{array}{l}\text { Domestic chores, palm } \\
\text { weaver }\end{array}$ & & Yes & & & & & 7 & \\
\hline 64 & Male & & Spanish & $\begin{array}{l}\text { Agriculture, mescal } \\
\text { production, palm weaver, } \\
\text { shepherd }\end{array}$ & & Yes & & & & & & \\
\hline 65 & Male & 73 & Spanish & Agriculture, palm weaver & & Yes & & 18 & Yes & & & \\
\hline 66 & Female & 51 & $\begin{array}{l}\text { Spanish, } \\
\text { Ixcatec }\end{array}$ & $\begin{array}{l}\text { Domestic chores, palm } \\
\text { weaver }\end{array}$ & $\begin{array}{l}\text { Key } \\
\text { participant }\end{array}$ & Yes & Yes & 2 & & & & \\
\hline 67 & Male & 20 & Spanish & Agriculture, palm weaver & & & Yes & & & & & \\
\hline 68 & Male & 61 & Spanish & Agriculture, palm weaver & & Yes & & & & & & \\
\hline 69 & Male & & Spanish & Student & & & Yes & & & & & \\
\hline 70 & Female & 71 & $\begin{array}{l}\text { Spanish, } \\
\text { Ixcatec }\end{array}$ & $\begin{array}{l}\text { Domestic chores, palm } \\
\text { weaver }\end{array}$ & $\begin{array}{l}\text { Key } \\
\text { participant }\end{array}$ & Yes & Yes & 18 & & 4 & & \\
\hline 72 & Male & 86 & Spanish & Agriculture, palm weaver & & & & 11 & & & & \\
\hline 73 & Female & 82 & $\begin{array}{l}\text { Spanish, } \\
\text { Ixcatec }\end{array}$ & $\begin{array}{l}\text { Domestic chores, palm } \\
\text { weaver }\end{array}$ & $\begin{array}{l}\text { Key } \\
\text { participant }\end{array}$ & Yes & & & & 5 & & \\
\hline 74 & Male & 38 & Spanish & $\begin{array}{l}\text { Agriculture, construction } \\
\text { worker, palm weaver }\end{array}$ & & & Yes & & & & & \\
\hline 76 & Female & 65 & Spanish & $\begin{array}{l}\text { Domestic chores, palm } \\
\text { weaver }\end{array}$ & & Yes & Yes & & & 3 & & \\
\hline 77 & Male & 38 & Spanish & Agriculture, palm weaver & & & Yes & & & & & \\
\hline 78 & Female & 40 & Spanish & $\begin{array}{l}\text { Domestic chores, palm } \\
\text { weaver }\end{array}$ & & & & 10 & & & & \\
\hline 79 & Male & 59 & Spanish & $\begin{array}{l}\text { Agriculture, mescal } \\
\text { production, palm weaver, } \\
\text { construction worker }\end{array}$ & & & Yes & 20 & Yes & & & 5 \\
\hline
\end{tabular}


Table 1 Consultants' details and the activities in which they collaborated (Continued)

\begin{tabular}{|c|c|c|c|c|c|c|c|c|c|c|c|c|}
\hline ID & Sex & Age & Language & Main activities & $\begin{array}{l}\text { Participant } \\
\text { type }\end{array}$ & $\begin{array}{l}\text { Semiestructured } \\
\text { interviews }\end{array}$ & $\begin{array}{l}\text { Free } \\
\text { lists }\end{array}$ & $\begin{array}{l}\text { Surveys } \\
2012\end{array}$ & $\begin{array}{l}\text { In-depth } \\
\text { interviews }\end{array}$ & Homegarden & $\begin{array}{l}\text { Agricultural } \\
\text { field }\end{array}$ & $\begin{array}{l}\text { Mescal } \\
\text { factory }\end{array}$ \\
\hline 81 & Female & & Spanish & $\begin{array}{l}\text { domestic chores, palm } \\
\text { weaver }\end{array}$ & & & Yes & & & & & \\
\hline 82 & Female & 62 & Spanish & $\begin{array}{l}\text { Domestic chores, palm } \\
\text { weaver }\end{array}$ & & Yes & & & & 2 & & \\
\hline 83 & Female & 33 & $\begin{array}{l}\text { Spanish, } \\
\text { Ixcatec }\end{array}$ & $\begin{array}{l}\text { Domestic chores, palm } \\
\text { weaver }\end{array}$ & & & Yes & & Yes & & & \\
\hline 84 & Male & 14 & Spanish & Palm weaver, student & $\begin{array}{l}\text { Key } \\
\text { participant }\end{array}$ & Yes & & & & 6 & & \\
\hline 85 & Male & & Spanish & $\begin{array}{l}\text { Mescal production, palm } \\
\text { weaver }\end{array}$ & & Yes & & & & & & \\
\hline 87 & Female & & Spanish & $\begin{array}{l}\text { Domestic chores, palm } \\
\text { weaver }\end{array}$ & & Yes & & & & 9 & & \\
\hline 88 & Male & 57 & Spanish & Agriculture, palm weaver & & & Yes & & & & & \\
\hline 89 & Female & 72 & Spanish & $\begin{array}{l}\text { Domestic chores, palm } \\
\text { weaver }\end{array}$ & & & Yes & & & & & \\
\hline 90 & Male & 26 & Spanish & Agriculture, palm weaver & & & Yes & & Yes & & & \\
\hline 91 & Male & 80 & Spanish & Agriculture, palm weaver & & & Yes & 19 & & & & \\
\hline 93 & Female & 66 & $\begin{array}{l}\text { Spanish, } \\
\text { Ixcatec }\end{array}$ & $\begin{array}{l}\text { Domestic chores, palm } \\
\text { weaver, shepherdess }\end{array}$ & $\begin{array}{l}\text { Key } \\
\text { participant }\end{array}$ & Yes & Yes & 17 & & 1 & & \\
\hline 95 & Male & 64 & Spanish & $\begin{array}{l}\text { Agriculture, mescal } \\
\text { production, palm weaver }\end{array}$ & $\begin{array}{l}\text { Key } \\
\text { participant }\end{array}$ & Yes & Yes & 7 & & & & \\
\hline 97 & Female & 79 & $\begin{array}{l}\text { Spanish, } \\
\text { Ixcatec }\end{array}$ & $\begin{array}{l}\text { Domestic chores, palm } \\
\text { weaver }\end{array}$ & $\begin{array}{l}\text { Key } \\
\text { participant }\end{array}$ & Yes & & 14 & & 11 & & \\
\hline 98 & Male & 88 & $\begin{array}{l}\text { Spanish, } \\
\text { Ixcatec }\end{array}$ & Palm weaver & $\begin{array}{l}\text { Key } \\
\text { participant }\end{array}$ & Yes & & 3 & & 14 & & \\
\hline 100 & Female & 84 & $\begin{array}{l}\text { Spanish, } \\
\text { Ixcatec }\end{array}$ & $\begin{array}{l}\text { Domestic chores, palm } \\
\text { weaver }\end{array}$ & $\begin{array}{l}\text { Key } \\
\text { participant }\end{array}$ & Yes & Yes & 4 & & & & \\
\hline 101 & Female & 94 & $\begin{array}{l}\text { Spanish, } \\
\text { Ixcatec }\end{array}$ & $\begin{array}{l}\text { Domestic chores, palm } \\
\text { weaver }\end{array}$ & & Yes & & & & & & \\
\hline 102 & Female & 33 & Spanish & $\begin{array}{l}\text { Domestic chores, palm } \\
\text { weaver }\end{array}$ & & & & 13 & & & & \\
\hline 103 & Male & 25 & Spanish & Agriculture, shepherd & $\begin{array}{l}\text { Key } \\
\text { participant }\end{array}$ & Yes & Yes & & & 15 & & \\
\hline 104 & Female & 39 & Spanish & $\begin{array}{l}\text { Domestic chores, palm } \\
\text { weaver }\end{array}$ & & Yes & & & & 1 & & \\
\hline 106 & Male & 55 & Spanish & $\begin{array}{l}\text { Agriculture, mescal } \\
\text { production, palm weaver }\end{array}$ & & & Yes & & & & & \\
\hline 107 & Male & & Spanish & Agriculture & & & & 8 & & & & \\
\hline 108 & Female & 92 & $\begin{array}{l}\text { Spanish, } \\
\text { Ixcatec }\end{array}$ & $\begin{array}{l}\text { Domestic chores, palm } \\
\text { weaver }\end{array}$ & & Yes & & & & & & \\
\hline 109 & Female & 32 & Spanish & $\begin{array}{l}\text { Domestic chores, palm } \\
\text { weaver }\end{array}$ & & & Yes & & Yes & & & \\
\hline 110 & Female & & Spanish & Nurse & & Yes & & & & & & \\
\hline 111 & Female & 24 & Spanish & $\begin{array}{l}\text { Domestic chores, nurse } \\
\text { assistant }\end{array}$ & & Yes & & & & & & \\
\hline 113 & Female & 48 & Spanish & $\begin{array}{l}\text { Domestic chores, palm } \\
\text { weaver }\end{array}$ & & Yes & & & Yes & 6 & & \\
\hline 114 & Female & 50 & Spanish & $\begin{array}{l}\text { Domestic chores, palm } \\
\text { weaver }\end{array}$ & & & & & Yes & & & \\
\hline 115 & Male & 57 & Spanish & Agriculture, palm weaver & & & & & Yes & & & \\
\hline 116 & Female & 55 & Spanish & $\begin{array}{l}\text { Domestic chores, palm } \\
\text { weaver }\end{array}$ & & & & & Yes & 18 & & \\
\hline
\end{tabular}


Table 1 Consultants' details and the activities in which they collaborated (Continued)

\begin{tabular}{|c|c|c|c|c|c|c|c|c|c|c|c|c|}
\hline ID & Sex & Age & Language & Main activities & $\begin{array}{l}\text { Participant } \\
\text { type }\end{array}$ & $\begin{array}{l}\text { Semiestructured } \\
\text { interviews }\end{array}$ & $\begin{array}{l}\text { Free } \\
\text { lists }\end{array}$ & $\begin{array}{l}\text { Surveys } \\
2012\end{array}$ & $\begin{array}{l}\text { In-depth } \\
\text { interviews }\end{array}$ & Homegarden & $\begin{array}{l}\text { Agricultural } \\
\text { field }\end{array}$ & $\begin{array}{l}\text { Mescal } \\
\text { factory }\end{array}$ \\
\hline 117 & Male & 37 & Spanish & Agriculture, palm weaver & & & & & Yes & & & \\
\hline 118 & Male & 31 & Spanish & Agriculture, palm weaver & & & & & Yes & & & \\
\hline 119 & Female & 46 & Spanish & $\begin{array}{l}\text { Domestic chores, palm } \\
\text { weaver }\end{array}$ & & & & & Yes & & & \\
\hline 120 & Female & 35 & Spanish & $\begin{array}{l}\text { Domestic chores, palm } \\
\text { weaver }\end{array}$ & & & & & Yes & & & \\
\hline 121 & Male & 39 & Spanish & $\begin{array}{l}\text { Agriculture, construction } \\
\text { worker, palm weaver }\end{array}$ & & & & & Yes & & & \\
\hline 122 & Female & 71 & Spanish & $\begin{array}{l}\text { Domestic chores, palm } \\
\text { weaver }\end{array}$ & & & & & Yes & & & \\
\hline 123 & Female & 74 & Spanish & $\begin{array}{l}\text { Domestic chores, palm } \\
\text { weaver }\end{array}$ & & & & & Yes & 20 & & \\
\hline 124 & Female & & Spanish & $\begin{array}{l}\text { Domestic chores, palm } \\
\text { weaver }\end{array}$ & & & & & Yes & & & \\
\hline 125 & Female & 81 & Spanish & $\begin{array}{l}\text { Domestic chores, palm } \\
\text { weaver }\end{array}$ & & & & & Yes & 21 & & \\
\hline 126 & Female & 70 & Spanish & $\begin{array}{l}\text { Domestic chores, palm } \\
\text { weaver }\end{array}$ & & & & & Yes & & & \\
\hline 127 & Female & 31 & Spanish & Domestic chores, commerce & & & & & Yes & & & \\
\hline 129 & Male & & Spanish & $\begin{array}{l}\text { Agriculture, mescal } \\
\text { production }\end{array}$ & & & & & & & & 3 \\
\hline 130 & Male & & Spanish & $\begin{array}{l}\text { Agriculture, mescal } \\
\text { production }\end{array}$ & & & & & & & & 4 \\
\hline 131 & Male & & Spanish & $\begin{array}{l}\text { Agriculture, mescal } \\
\text { production }\end{array}$ & & & & & & & & 1 \\
\hline
\end{tabular}

index $[12,15]$. We performed Kruskal-Wallis tests in order to identify differences among scores of management intensity of plants with ceremonial, edible, and medicinal uses. With the data of selected species, we performed two PCA per use type, one with the variables of the management type matrix and the other with the sociocultural and ecological variables (Table 2); the scores were used as an index of management intensity and a risk index, respectively. The relationships between risk and management intensity were analyzed through regression analyses.

Partial canonical analyses were performed using canonical correspondence analysis (CCA) per use type, in order to identify which fraction of the variation in plant management is explained by sociocultural and ecological factors and the effect of the interaction between the two types of variables $[12,15,16,41]$. For each analysis, we used three matrices, a Y matrix containing the response management variables, an $\mathrm{X}$ matrix with sociocultural explanatory variables, and a W matrix of the ecological explanatory variables. Through this method, we conducted partial analyses with different combinations of the matrixes of the explanatory variables: (1) CCA for matrix Y, (2) CCA with matrix Y explained by matrix X, (3) CCA with matrix Y explained by matrix W, and (4) CCA with matrix $\mathrm{Y}$ explained by the combined effect of the $\mathrm{W}+\mathrm{X}$ matrices. The total constrained eigenvalue of each analysis was tallied to evaluate how much the management intensity matrix is explained by the sociocultural and ecological variables.

For each analysis, the sum of all canonical eigenvalues divided by the sum of all canonical eigenvalues of the CA with management data allowed calculating the corresponding fraction of variation explained by the analysis. The significance of the models was estimated by permutation tests. All analyses were conducted through the $\mathrm{R}$ software [42]. In the PCA and CCA analyses of medicinal plants, Agave potatorum and Quercus acutifolia were excluded since these species were outliers.

\section{Results}

\section{Ceremonial plants}

We recorded 128 ceremonial plant species, 78 of them native or naturalized (Table 3); 22 species are considered by people to be basic for their life (Table 4). We recorded 48 species used for altars at homes for venerating Saints (Fig. 2). The most valuable species are those appreciated for their beauty and odor of their flowers (Table 5). As part of the communitarian celebrations, local people use 33 species as incense-like resin called copal (Bursera spp.), in the religious processions (Litsea glaucescens), and as ornaments offered to Saints (orchids, Dasylirion serratifolium, Tillandsia grandis, Beaucarnea stricta) (Fig. 2). 
Table 2 Criteria of variables considered for analyzing sociocultural and ecologic factors that influence management intensity

\begin{tabular}{|c|c|c|c|}
\hline Matrix & Variables & Description & Criterion and values \\
\hline \multirow{12}{*}{$\begin{array}{l}\text { Sociocultural } \\
(\text { matrix X) }\end{array}$} & Uses number & Total number of registered uses & 1 per use \\
\hline & SI basic plants & $\begin{array}{l}\text { Sutrop's cognitive prominence index } \\
\text { of plants considered as basic to live } \\
\text { in Ixcatlán }\end{array}$ & $\begin{array}{l}0-1 ; 0 \text { is a value assigned when no consultant } \\
\text { mentioned the plant, and } 1 \text { is a theoretical value } \\
\text { that a plant could have if all consultants } \\
\text { mentioned it at first rank [39] }\end{array}$ \\
\hline & SI by use type & $\begin{array}{l}\text { Sutrop's cognitive prominence index } \\
\text { of plants by category (edible, medicinal, } \\
\text { ceremonial) }\end{array}$ & $\begin{array}{l}0-1 ; 0 \text { is a value assigned when no consultant } \\
\text { mentioned the plant, and } 1 \text { is a theoretical value } \\
\text { that a plant could have if all consultants } \\
\text { mentioned it at first rank [39] }\end{array}$ \\
\hline & Consumption & $\begin{array}{l}\text { Proportion of families that have consumed } \\
\text { the species for the analyzed use in the } \\
\text { last } 2 \text { years }\end{array}$ & $0-1$ \\
\hline & Use frequency & $\begin{array}{l}\text { Frequency of consumption per availability } \\
\text { season/year for analyzed use (2) }\end{array}$ & $\begin{array}{l}0=\text { never been consumed; } 1 \leq 5 \text { times in their } \\
\text { life; } 2 \geq 5 \text { times in their life but not regularly; } \\
3=1 \text { time every } 2 \text { availability seasons; } 4=1 \\
\text { a } 2 \text { times by availability season; } 5=3 \text { a } 10 \text { times } \\
\text { by availability season }\end{array}$ \\
\hline & Recognized variants & Types or varieties recognized (1) & $\begin{array}{l}0=\text { no varieties are recognized; } 1=\text { varieties are } \\
\text { recognized for a plant, but each variety is a } \\
\text { different species; } 2=\text { varieties are recognized for } \\
\text { a species but are used equally; } 3=\text { varieties are } \\
\text { recognized and have specialized use }\end{array}$ \\
\hline & Economic interchange & Type of commercial exchange (1) & $\begin{array}{l}1=\text { direct consumption; } 2=\text { bartering; } 3=\text { sold } \\
\text { inside the village by collectors of the community } \\
\text { or comers who obtain it in other places; } \\
4=\text { harvested inside the village and are marketed } \\
\text { outside (plants or products) }\end{array}$ \\
\hline & Reciprocity interchange & Type of exchange of reciprocity (1) & $\begin{array}{l}1=\text { direct consumption; } 2=\text { it is given and } \\
\text { received as a gift to/from others; } 3=\text { it is offered } \\
\text { in communal celebrations (harvested by sponsors } \\
\text { celebration or families who offer the plants to } \\
\text { sponsor celebration) }\end{array}$ \\
\hline & Sociocultural strategies & $\begin{array}{l}\text { Strategies to obtain the plant when scarce } \\
\text { or unavailable (1) }\end{array}$ & $\begin{array}{l}0=\text { nothing; } 1=\text { mobility, look elsewhere; } \\
2=\text { substitution for other species or products; } \\
3=\text { store them; } 4=\text { ask someone to give them; } \\
5=\text { seek to obtain it by barter } 6=\text { buy them }\end{array}$ \\
\hline & Useful parts ${ }^{\mathrm{a}}$ & Number of useful parts & 1 per used part \\
\hline & Harvest effort ${ }^{a}$ & Invested effort in harvest in a journey (1) & $\begin{array}{l}1=\text { opportunist; } 2=\text { journey dedicated to } \\
\text { harvest the species }\end{array}$ \\
\hline & Tools for harvest ${ }^{a}$ & $\begin{array}{l}\text { Use of tools, supplies, and vehicles in } \\
\text { harvest (1) }\end{array}$ & $\begin{array}{l}\text { None, only hands are used; } 1=\text { objects obtained } \\
\text { at harvest site; } \\
2=\text { knife, machete; } 2=\text { Arundo donax pole, } \\
\text { baskets, bags; } 3=\text { load animals, vehicles, } \\
\text { chainsaws }\end{array}$ \\
\hline \multirow[t]{5}{*}{$\begin{array}{l}\text { Ecological } \\
\text { (Matrix W) }\end{array}$} & Abundance perception & Abundance perception in the territory (2) & $\begin{array}{l}1=\text { very abundant; } 2=\text { abundant } 3=\text { regular } \\
\text { abundance; } 4=\text { scarce; } 5=\text { rare }\end{array}$ \\
\hline & Vulnerability & $\begin{array}{l}\text { Plant vulnerability to factors affecting } \\
\text { productivity, quality, and survival ( } 2 \text { ) }\end{array}$ & $\begin{array}{l}1=\text { nothing affects and always produces the } \\
\text { same; } 2 \text { = plague, drought, steady harvest, others }\end{array}$ \\
\hline & Life cycle & Life cycle type of the species & $1=$ annual $; 2=$ perennial \\
\hline & Reproduction & Reproduction type of the species & $1=$ sexual and asexual; 2 = sexual \\
\hline & Harvested parts & $\begin{array}{l}\text { Harvested parts for all use types of the } \\
\text { plant in function of survival, resprouting, } \\
\text { and reproductive capacity after useful } \\
\text { part harvest (1) }\end{array}$ & $\begin{array}{l}1=\text { living individual } ; 1=\text { dry branches; } \\
2=\text { exudates, thorns; } 3=\text { leaves; } 4=\text { sprout; } \\
5=\text { mature branches (lignified tissue/flowers); } \\
6=\text { fruits, seeds; } 7=\text { bark; } 8=\text { all flowers/fruits } \\
\text { of the season; } 9=\text { main stalk; } 9=\text { roots; } \\
10=\text { complete individuals }\end{array}$ \\
\hline
\end{tabular}


Table 2 Criteria of variables considered for analyzing sociocultural and ecologic factors that influence management intensity (Continued)

\begin{tabular}{|c|c|c|c|}
\hline Matrix & Variables & Description & Criterion and values \\
\hline & Nearness to harvest site ${ }^{a}$ & $\begin{array}{l}\text { Closeness perception of harvest sites } \\
\text { to consumption site (2) }\end{array}$ & $\begin{array}{l}1=\text { far away; } 2=\text { far; } 3=\text { not too far; } 4=\text { near; } \\
5=\text { at hand }\end{array}$ \\
\hline & Temporal availability ${ }^{\mathrm{a}}$ & $\begin{array}{l}\text { Temporal availability of the useful part } \\
\text { for the analyzed use (2) }\end{array}$ & $1=$ all year $; 2=$ months; $3=$ weeks $5=$ days \\
\hline \multirow[t]{7}{*}{$\begin{array}{l}\text { Management } \\
\text { (Response matrix } \\
\text { Y) }\end{array}$} & Collective regulations & Type of regulation for the harvest (1) & $\begin{array}{l}0=\text { without restrictions; } 1=\text { there are } \\
\text { "costumbres" traditions that indicate the techniques, } \\
\text { quantity, and occasions of harvest; } 2=\text { in addition } \\
\text { to communal agreements aimed at regulating the } \\
\text { access, they are aware that external institutions } \\
\text { protect the species; } 3=\text { complaints have been made } \\
\text { or penalties imposed }\end{array}$ \\
\hline & Management practices & Management practice type (1) & $\begin{array}{l}1=\text { gathering, forage; } 2=\text { gathering with care } \\
\text { to avoid damaging the plant; } 3=\text { tolerance; } \\
4=\text { enhancement; } 5=\text { protection; } 6=\text { transplanting } \\
\text { of individuals; } 7=\text { propagation }\end{array}$ \\
\hline & Artificial selection & Selection of individuals and propagules (1) & $\begin{array}{l}0=\text { without selection; } 1 \text { = selection of individuals } \\
\text { or parts that are collected for consumption; } \\
2=\text { selection of tolerated, protected or enhanced } \\
\text { individuals; } 3=\text { selection of individuals from which } \\
\text { seeds or cuttings are obtained to propagate }\end{array}$ \\
\hline & Management in AFS & $\begin{array}{l}\text { Species presence proportion in } \\
\text { homegardens, agricultural fields, } \\
\text { and mescal factories }\end{array}$ & $0-3$ \\
\hline & Practices number ${ }^{a}$ & $\begin{array}{l}\text { Number of management practices } \\
\text { carried out }\end{array}$ & 1 by type of practices \\
\hline & Maintaining labors ${ }^{\mathrm{a}}$ & $\begin{array}{l}\text { Type of labors carried out to protect, } \\
\text { enhance, and cultivate }\end{array}$ & $\begin{array}{l}1 \text { = prepare soil; fix to hosts; exclusion of predators } \\
\text { with fences, cages; removal of competitors; pruning, } \\
\text { removing dried or diseased leaves; mechanical } \\
\text { support; addition of forest soil, sand, ash, residues } \\
\text { of organic matter; addition of lime } \\
2 \text { = irrigation } \\
3=\text { infrastructure and special equipment for } \\
\text { maintenance }\end{array}$ \\
\hline & $\begin{array}{l}\text { Management system } \\
\text { type }^{\mathrm{a}}\end{array}$ & $\begin{array}{l}\text { System type where plant is managed } \\
\text { with respect to species natural } \\
\text { distribution (1) }\end{array}$ & $\begin{array}{l}1=\text { wild vegetation where plants are distributed } \\
\text { naturally; } 2=\text { homegardens, gardens in mescal factories } \\
\text { or "palenques," and agricultural fields, where plants } \\
\text { are naturally distributed; } 3=\text { homegardens, mescal } \\
\text { factories, and agricultural fields, where plants have } \\
\text { been carried; } 4 \text { = greenhouses and nurseries }\end{array}$ \\
\hline
\end{tabular}

Numbers in variable description indicate the following: (1) addition of the different values registered for the species; (2) average of category values mentioned by consultants

a Variables not included in principal component analysis and partial canonical analysis

Table 3 Management of native and naturalized species of Santa María Ixcatlán by use type

\begin{tabular}{llll}
\hline & Ceremonial & Edible & Medicinal \\
\hline Only gathered & 28 & 30 & 81 \\
Tolerated & 21 & 40 & 79 \\
Enhancement & 6 & 7 & 9 \\
Protection & 37 & 28 & 31 \\
Transplanting & 26 & 20 & 15 \\
Propagation & 18 & 11 & 12 \\
Total & 77 & 80 & 178 \\
\hline
\end{tabular}

Brahea spp. leaves blessed are used for weaving shoes for dead people. The copal resin is used in praying, altars, processions, masses, and funerary rites and for protecting against "aires" (negative feelings, dangerous situations that may cause illnesses or accidents).

Commercialization of ceremonial wild plants is uncommon, except the resin of Bursera spp., which is used for celebrating the day of the dead. People used to share part of flowers collected in forests or managed in homegardens (mainly Chiococca alba, Lindleya mespiloides, orchids, and copal resin (Bursera spp.)) and give them as presents to people who organize the communitarian feasts. Dasylirion serratifolium, Beaucarnea stricta, and Tillandsia grandis are involved in practices of reciprocity among most of the local households in communitarian feasts (Table 5). 


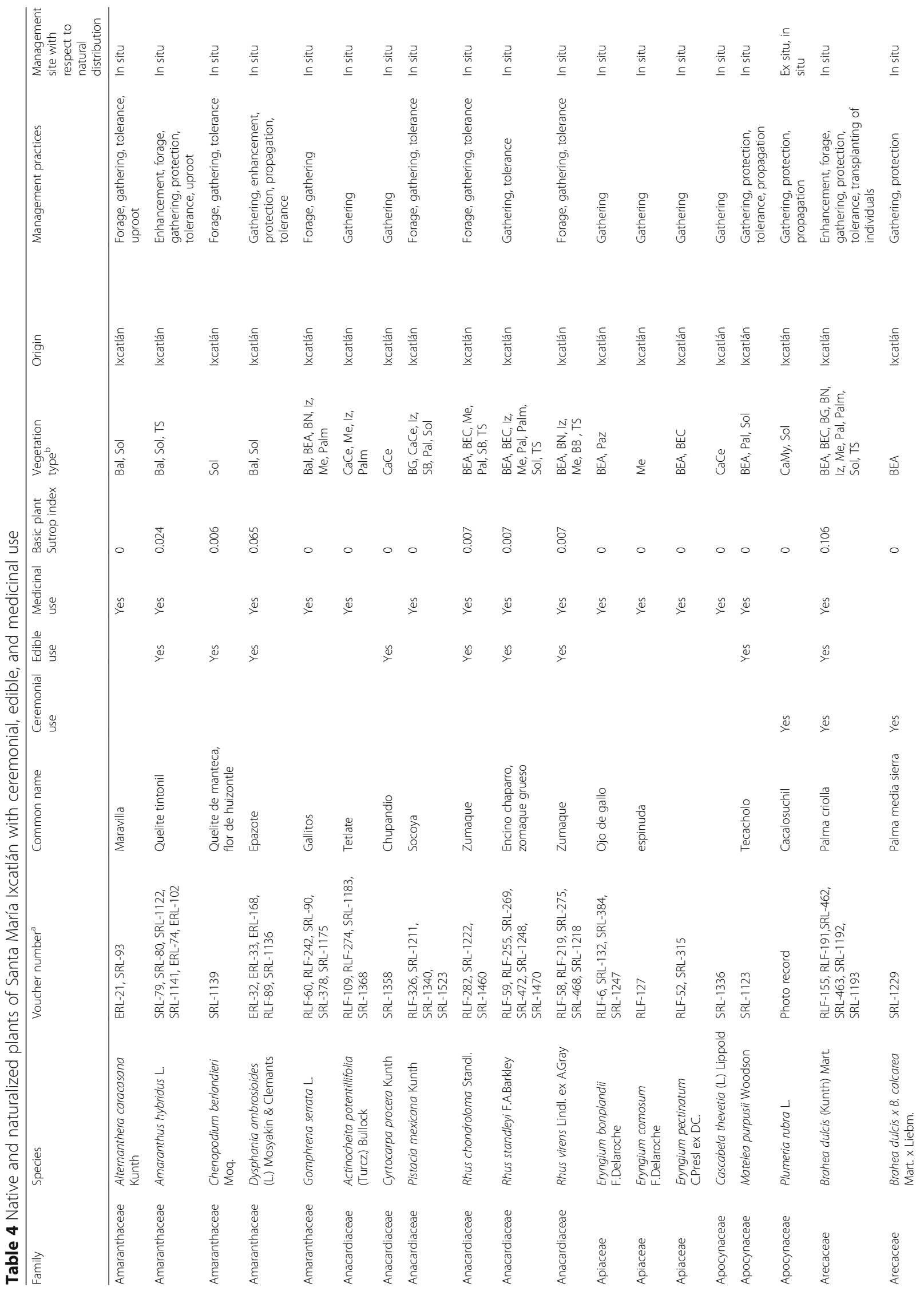




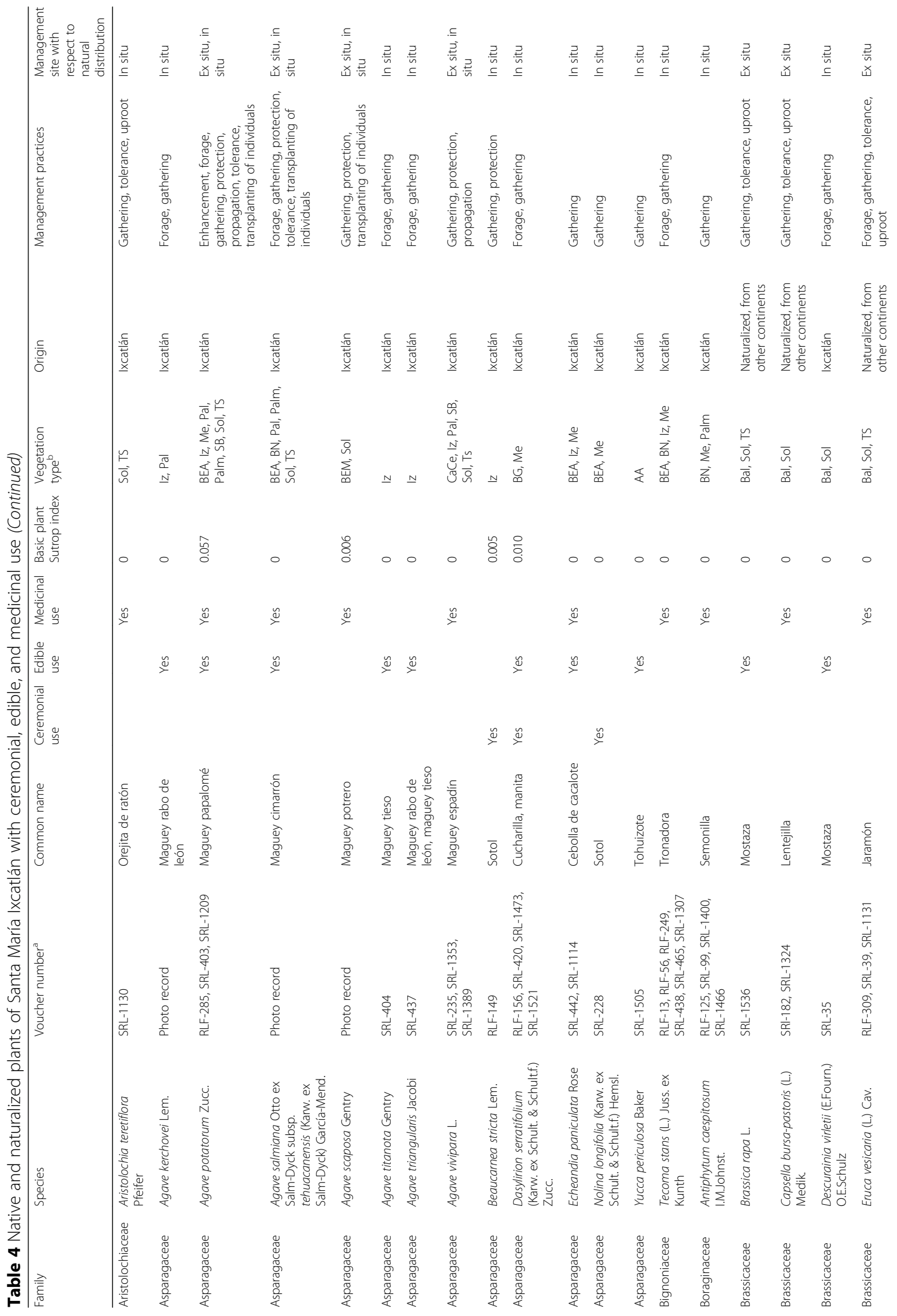




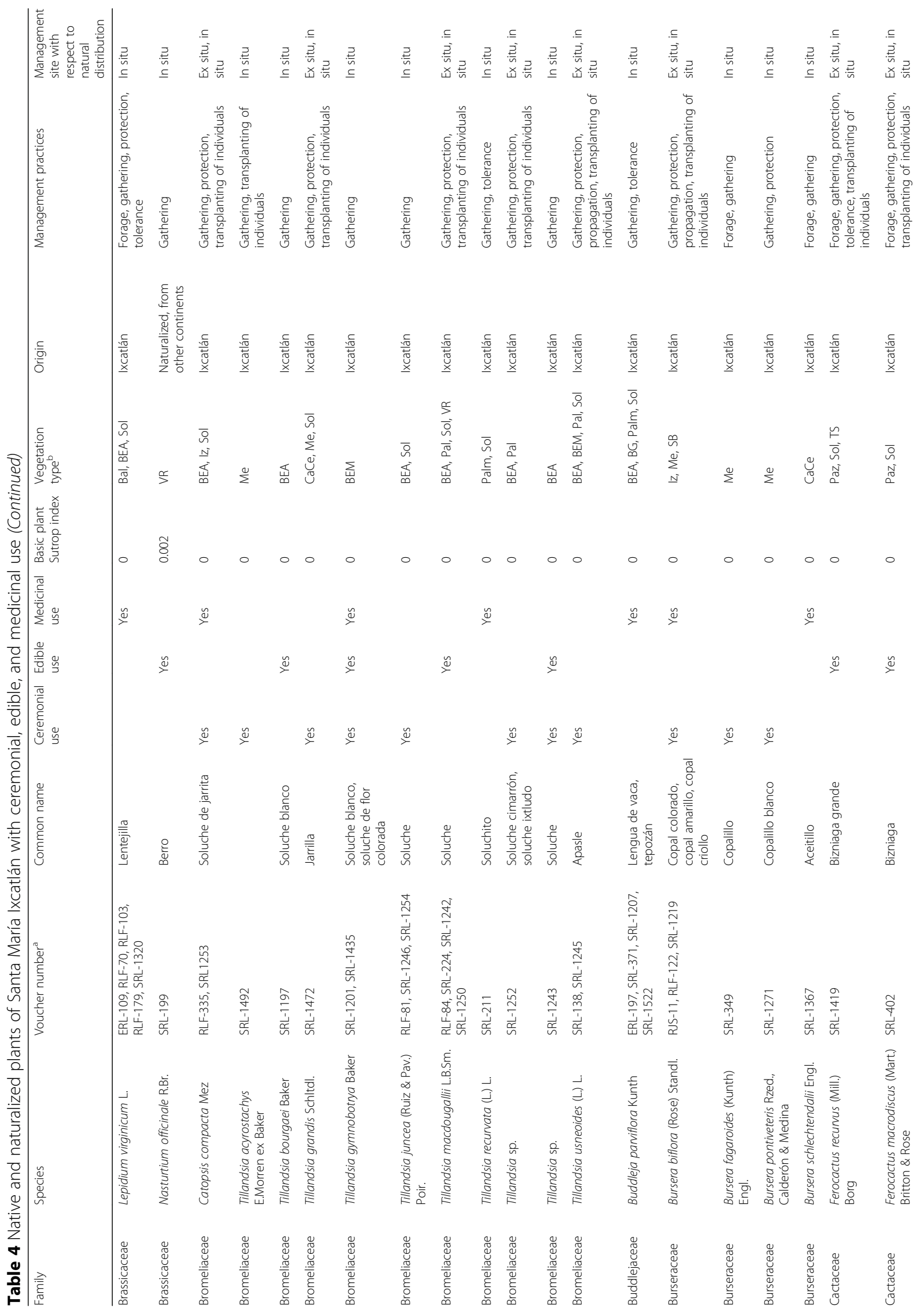




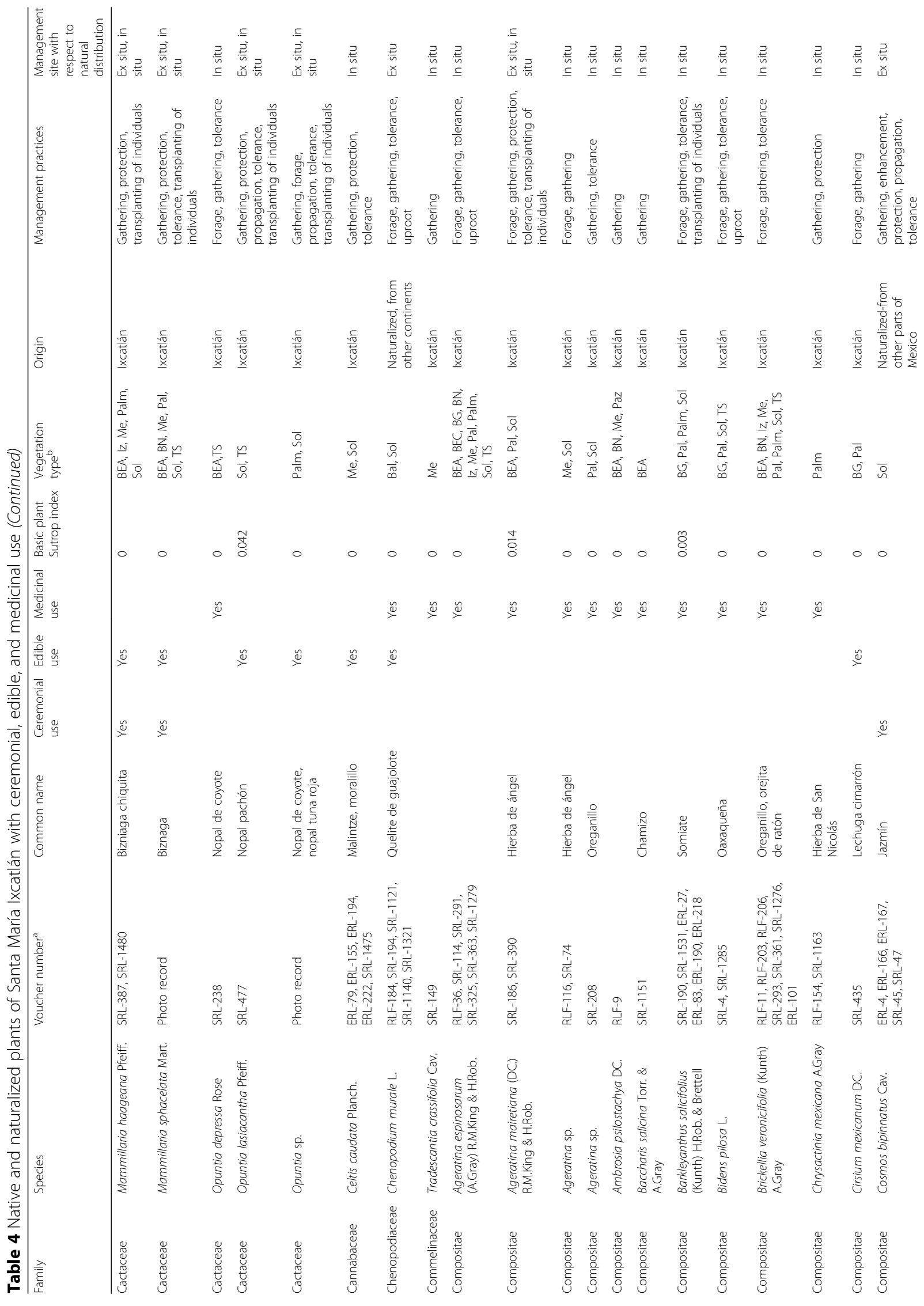




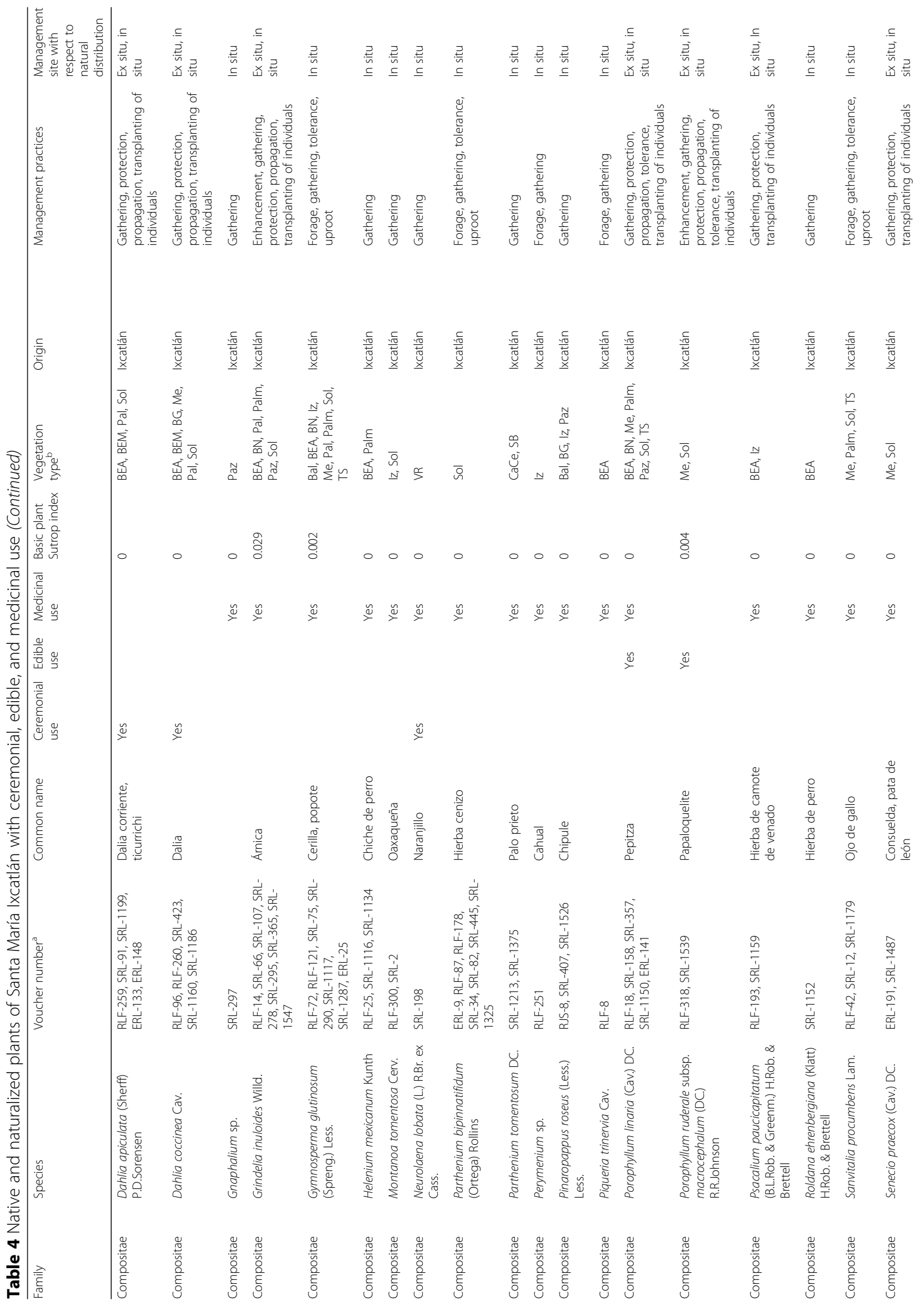




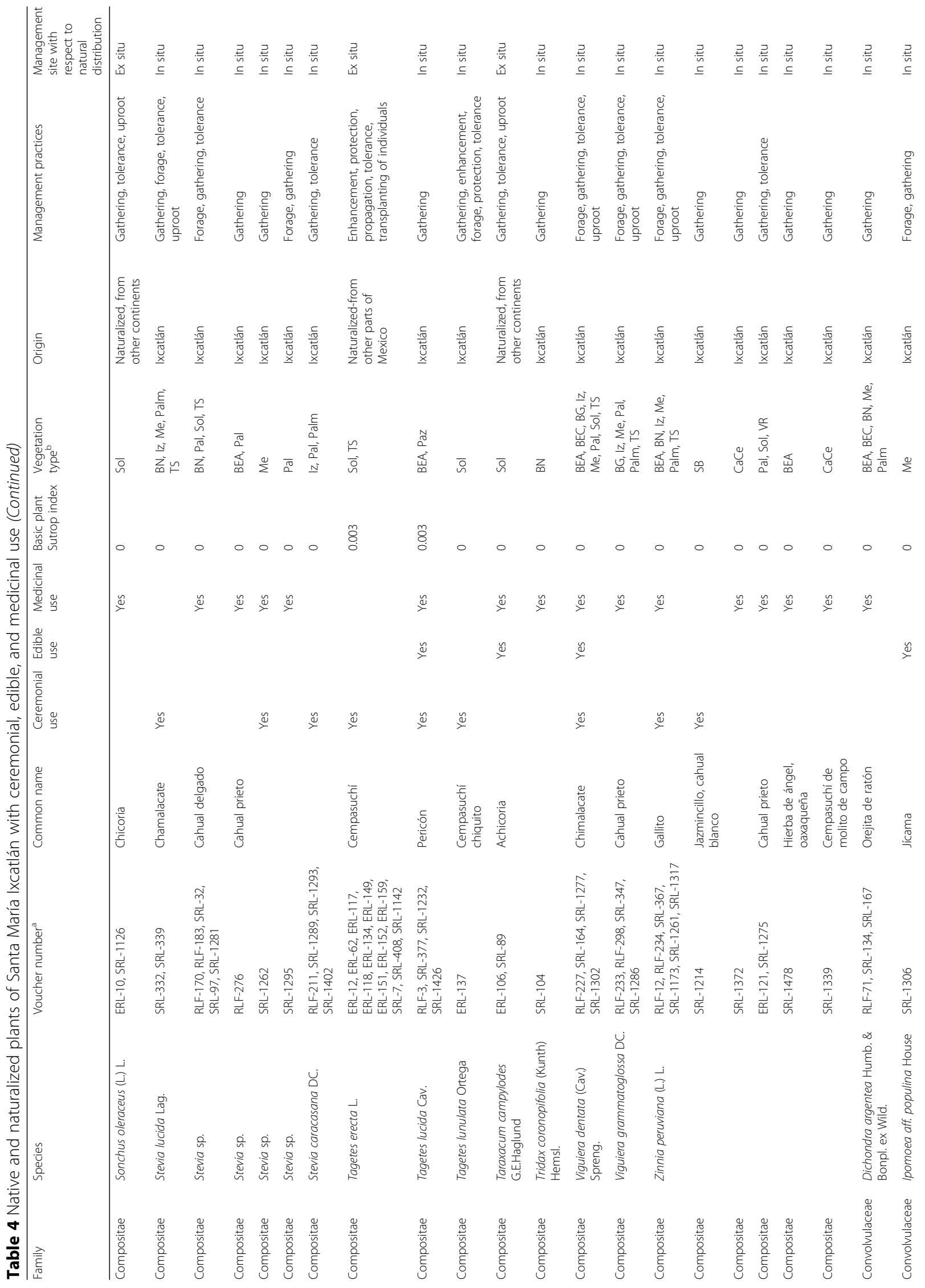




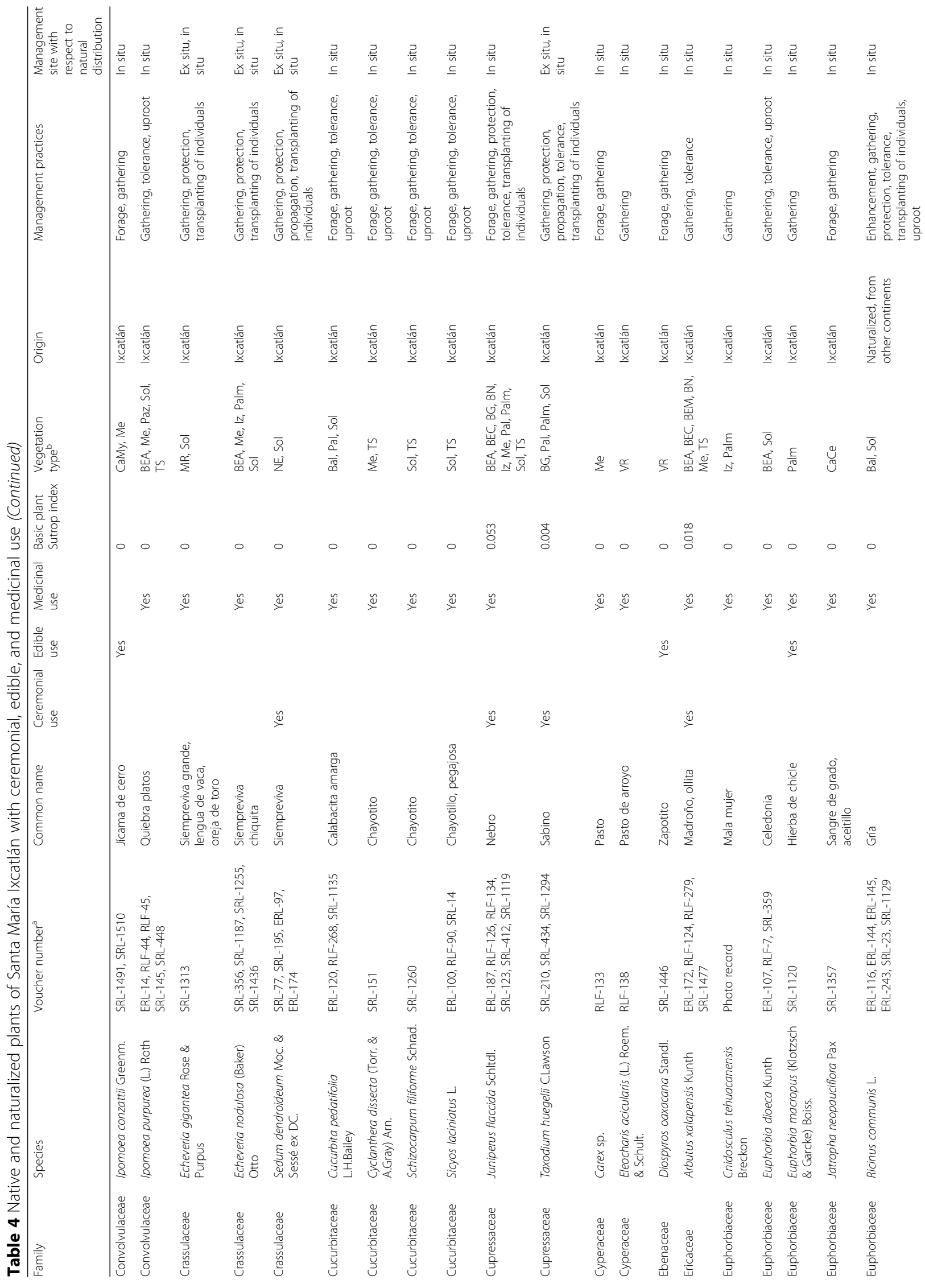




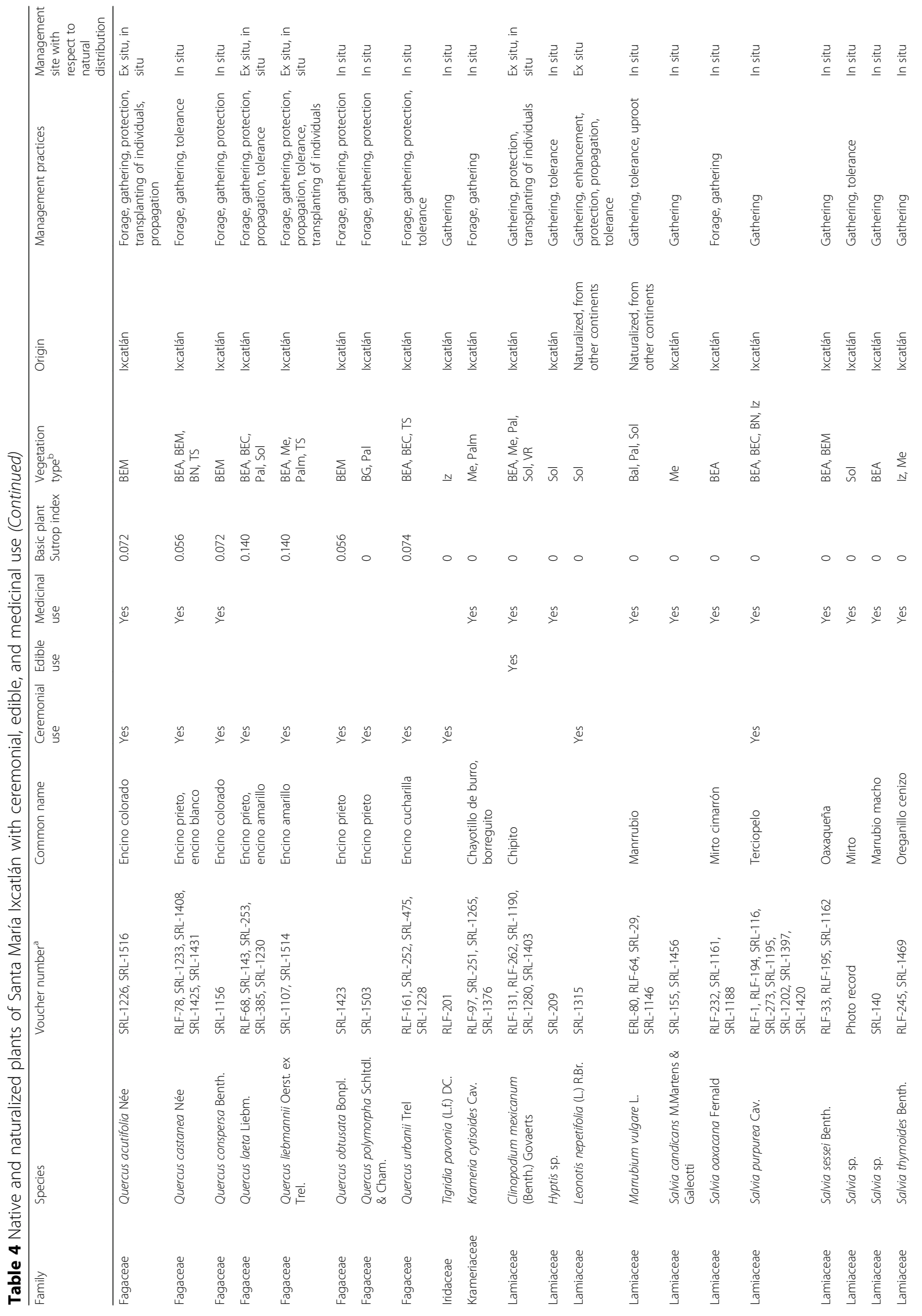




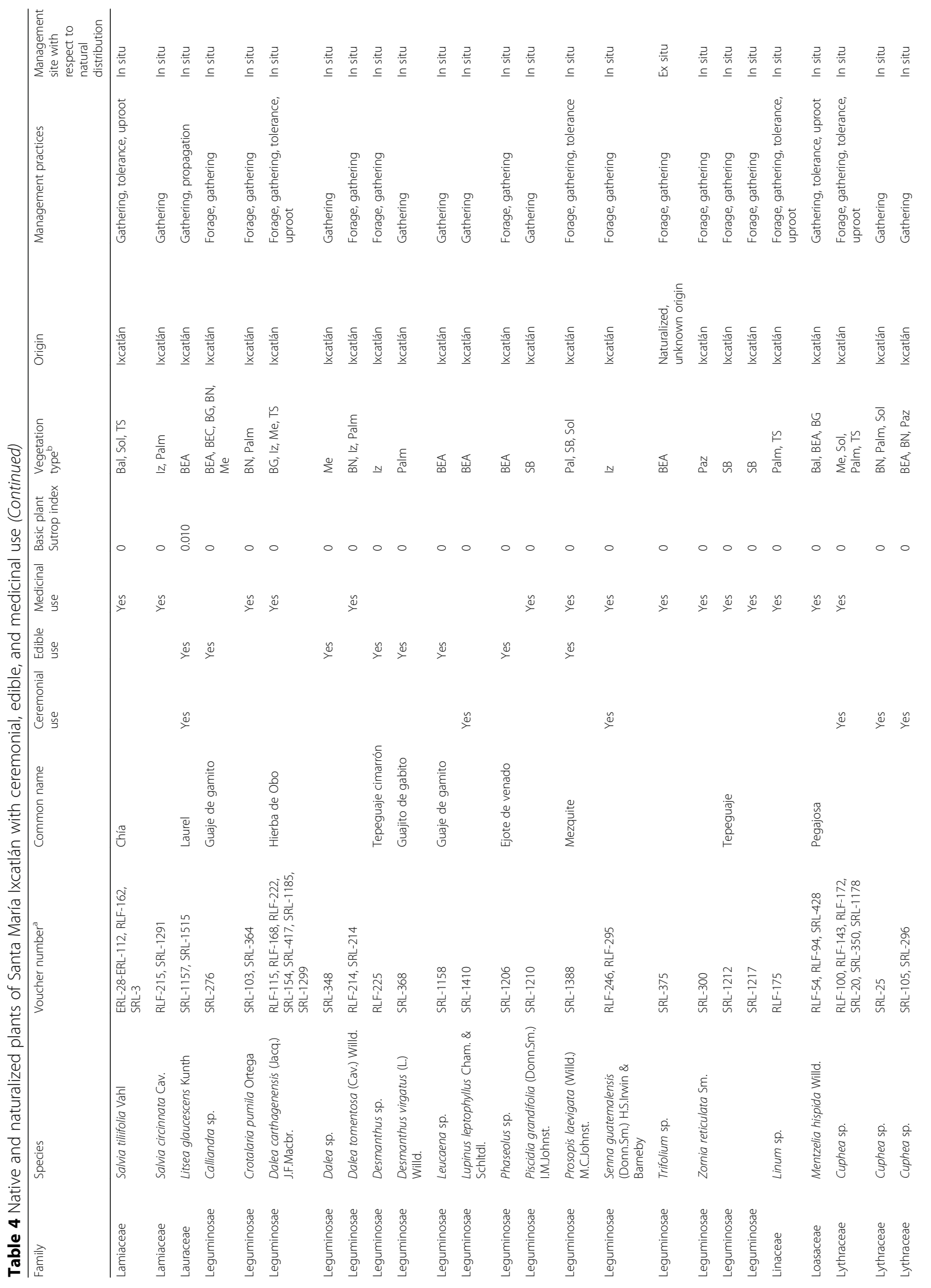




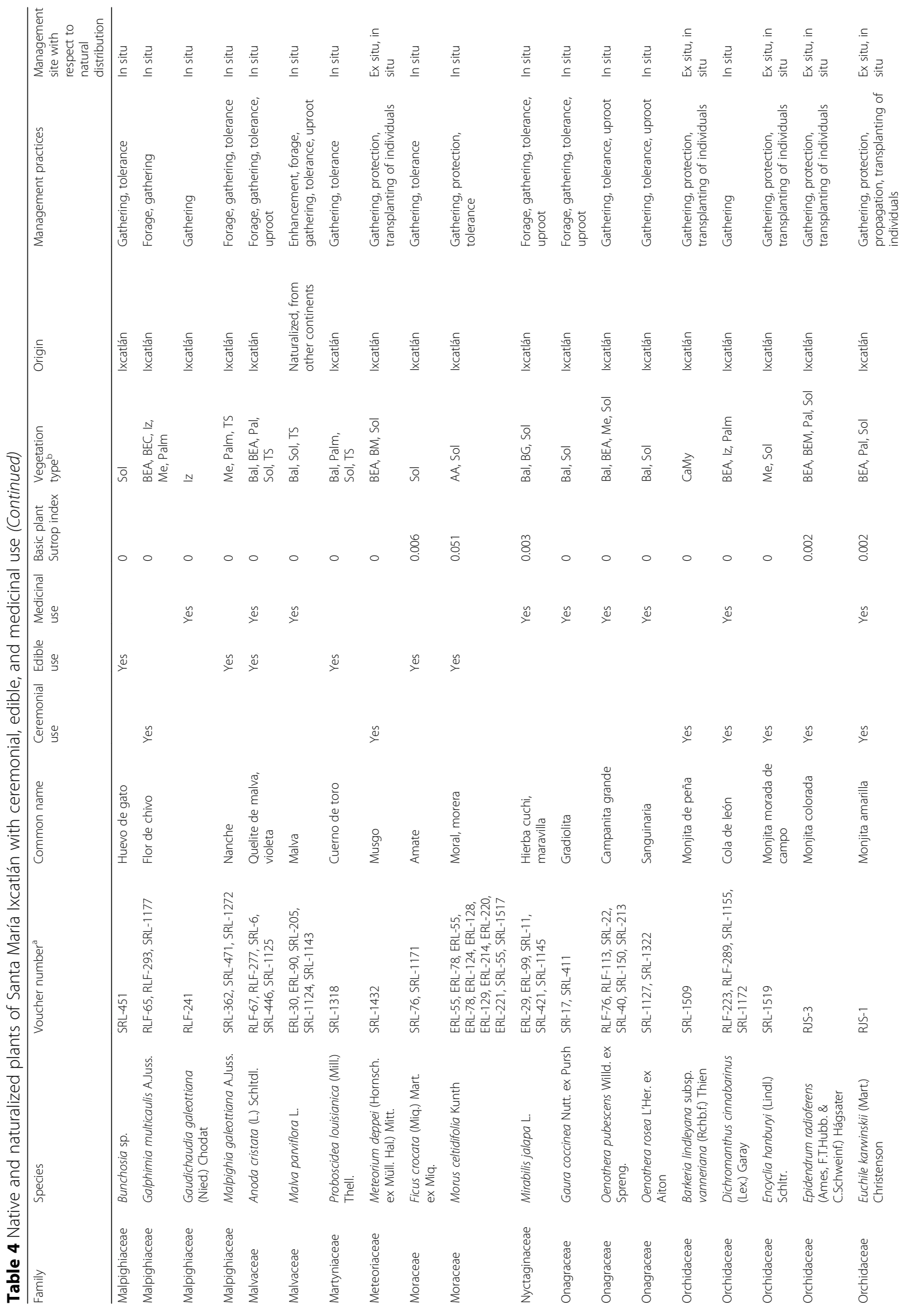




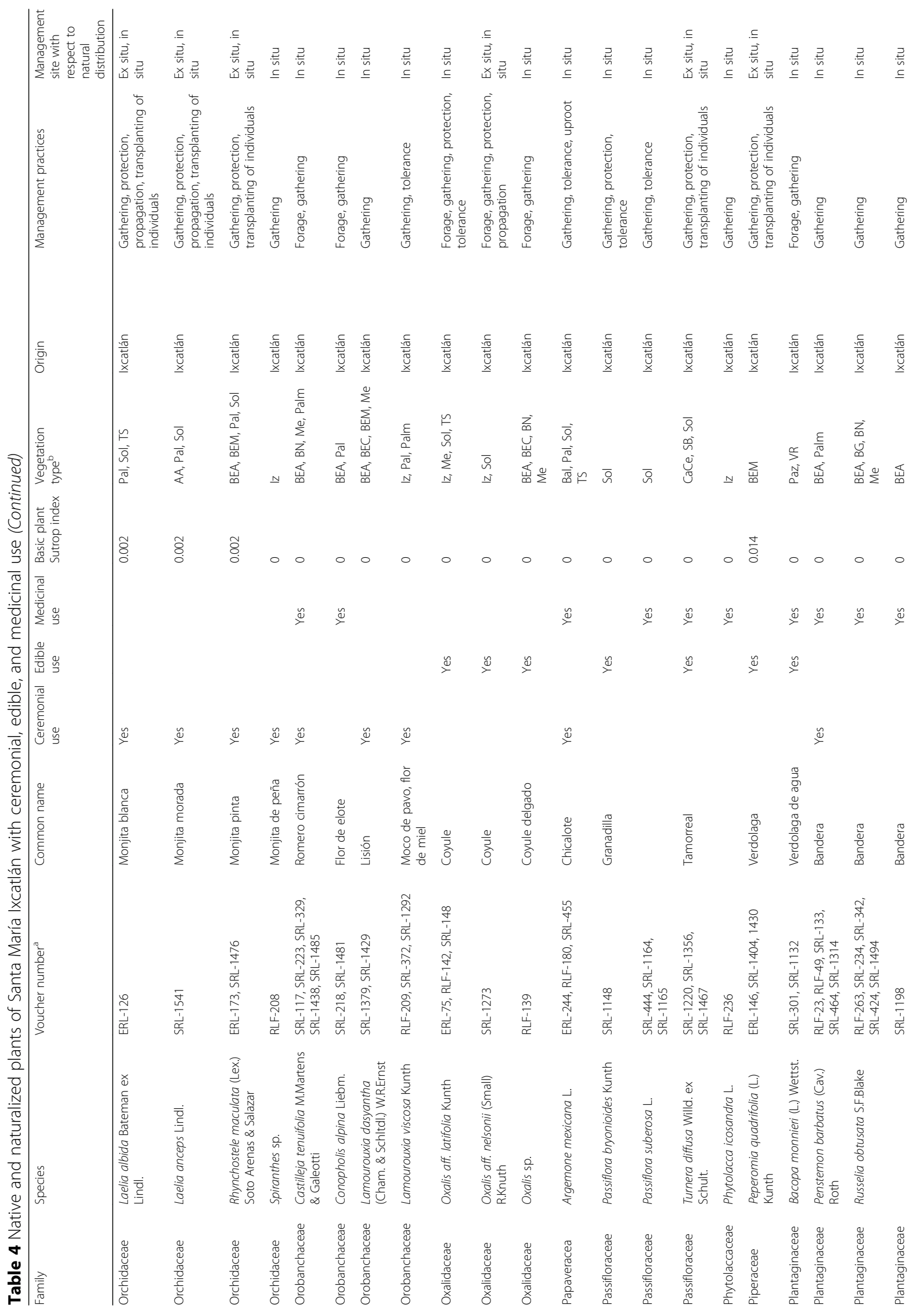




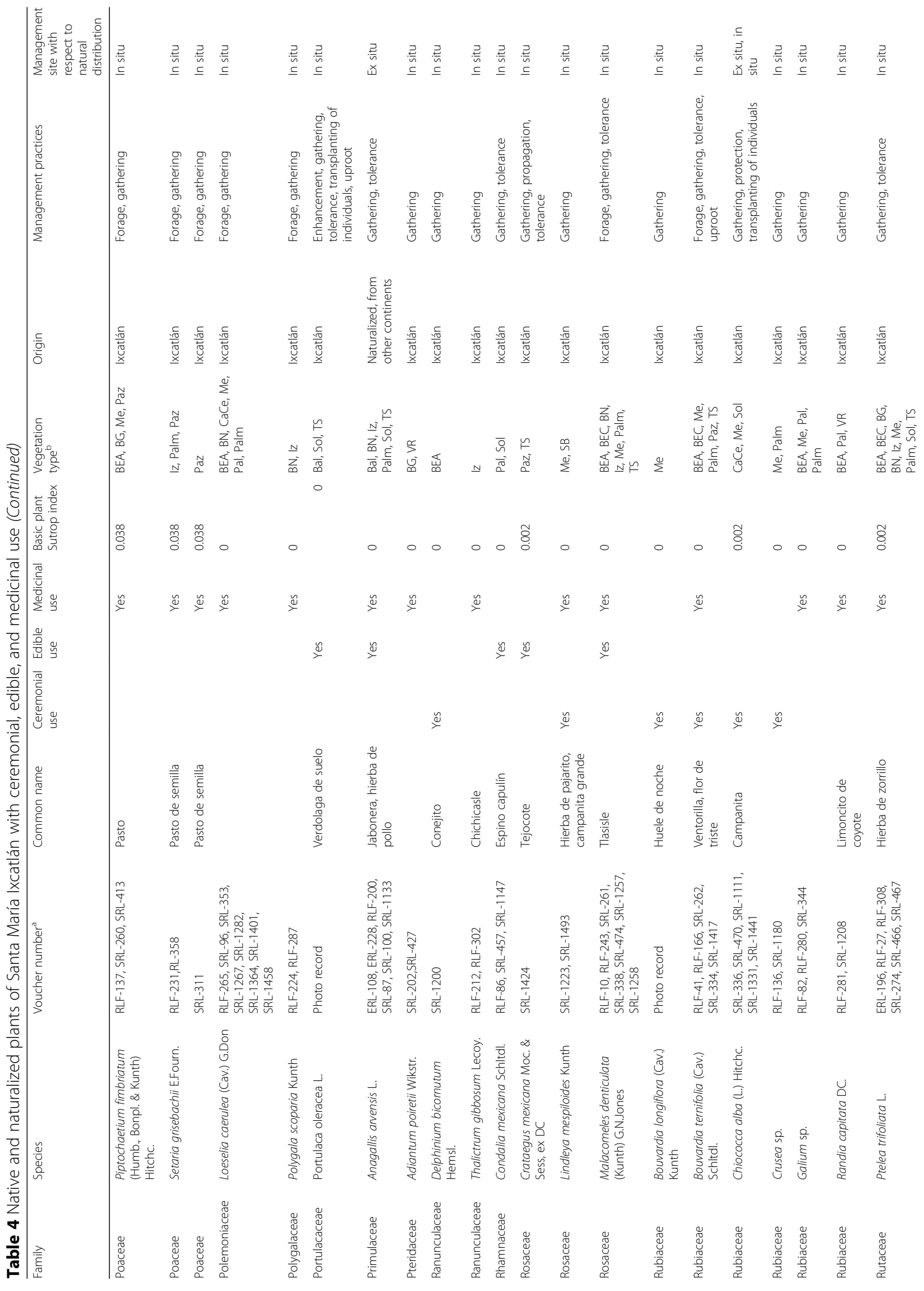




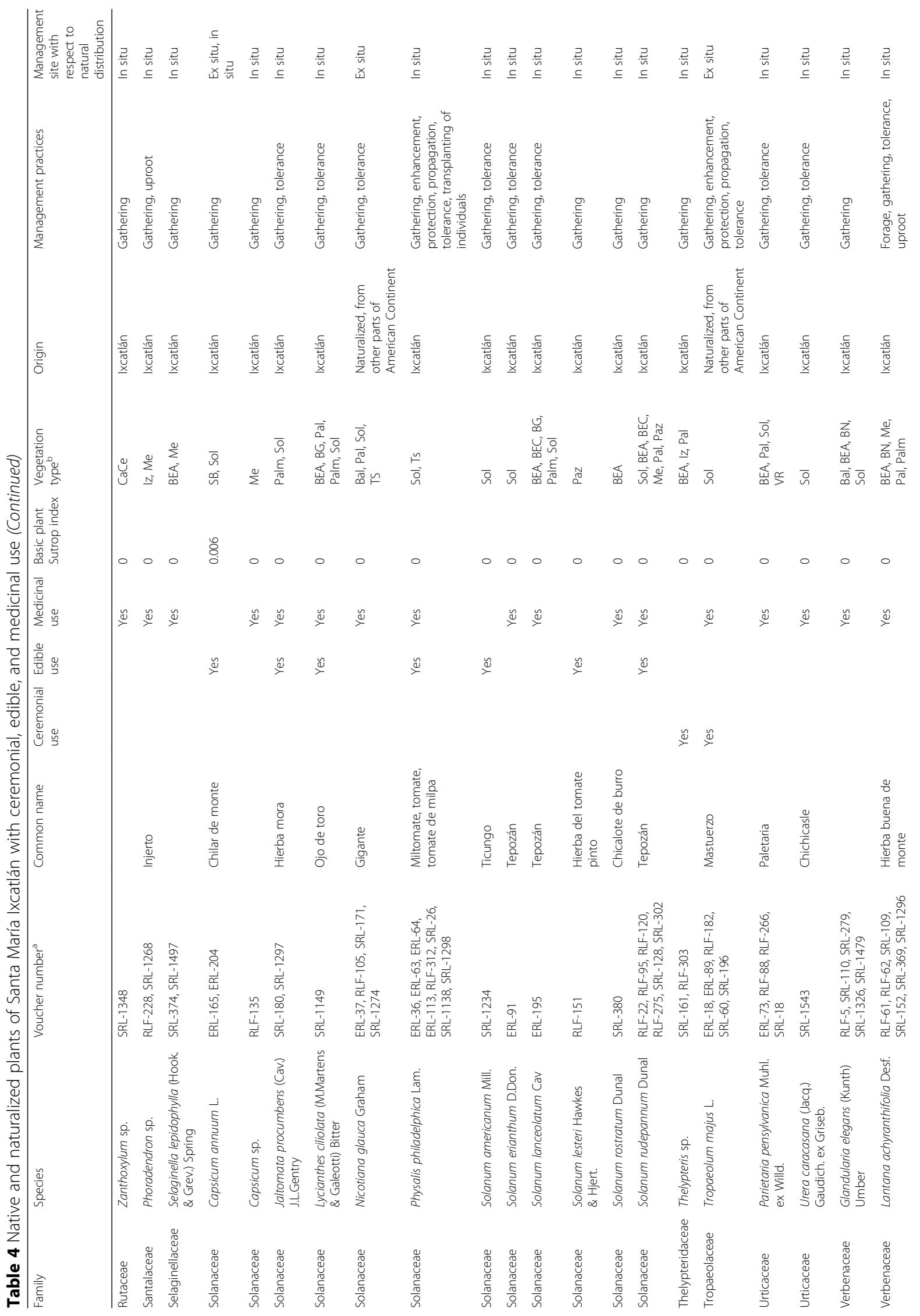


Rangel-Landa et al. Journal of Ethnobiology and Ethnomedicine (2017) 13:59

Page 24 of 43

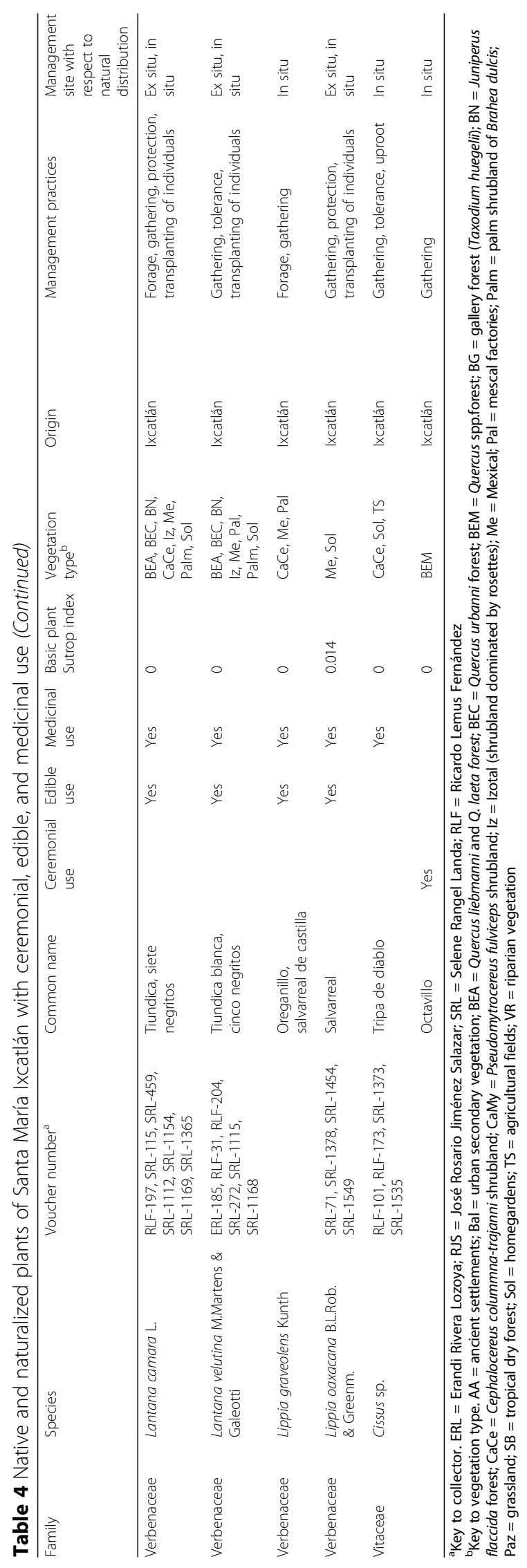




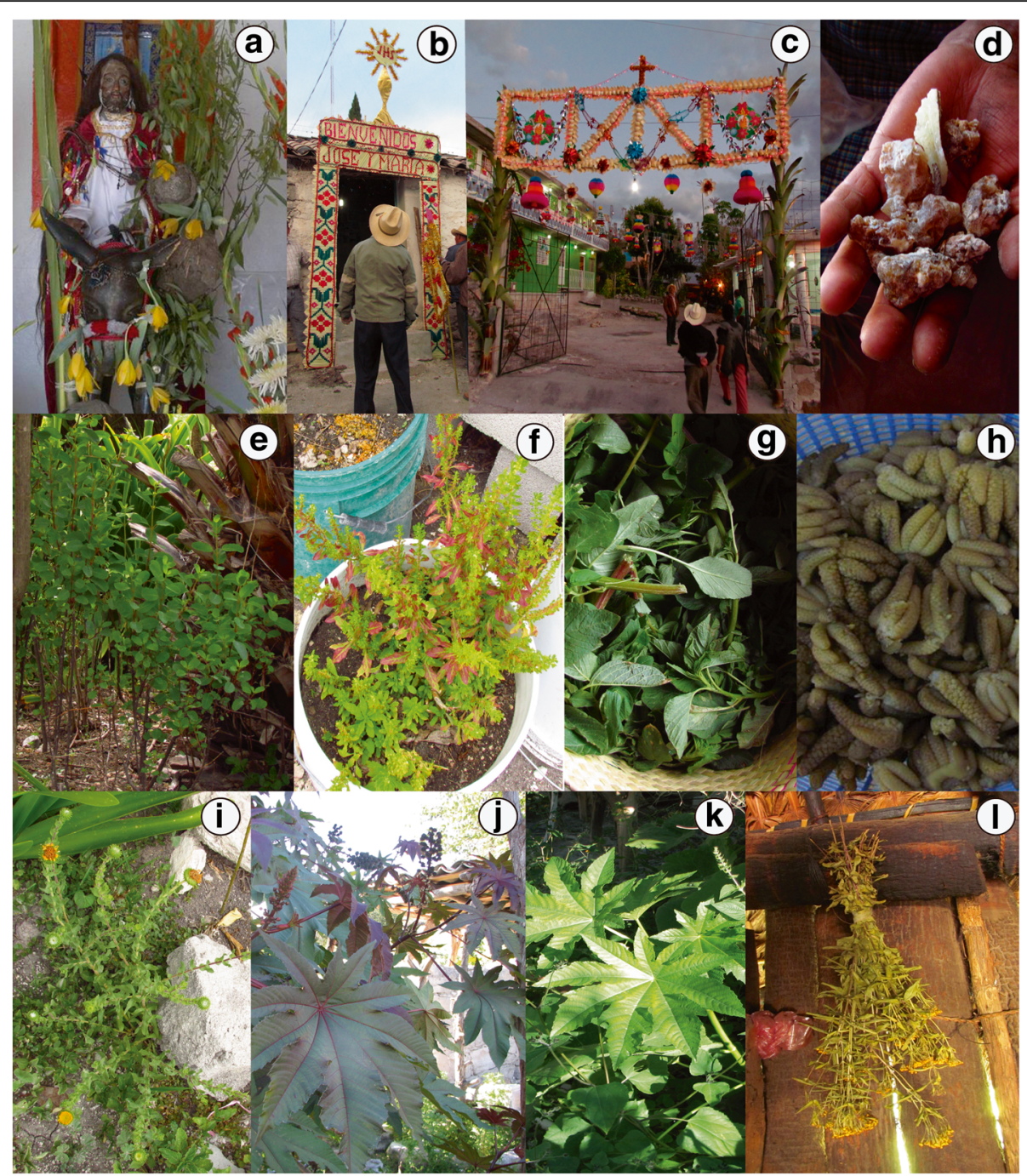

Fig. 2 Ceremonial, edible, and medicinal plants of Santa María Ixcatlán community. a Offering "adornment" of Brahea dulcis leaves, Euchile karwinskii flowers, Litsea glaucescens branches, and wasp honeycombs to San Ramón in Palm Sunday celebration. b Beaucarnea stricta arch to welcome the Saints in "posadas" celebrations. c Tillandsia grandis and Dasylirion serratifolium arch to welcome the Saints in "posadas" celebrations. d Bursera biflora resin. e Porophyllum ruderale subsp. macrocephalum cultivated in a homegarden. $\mathbf{f}$ Dysphania ambrosioides transplanted in a bucket to protect it from animals and to facilitate its care. $\mathbf{g}$ Tender branches of Amaranthus hybridus collected during agricultural labor; $\mathbf{h}$ Boiled floral buds of Dasylirion serratifolium. i Grindelia inuloides plant cultivated in a homegarden. $\mathbf{j}$ Red Ricinus communis variety managed in a homegarden. $\mathbf{k}$ White Ricinus communis variety. I Bunch of Tagetes lucida dry plants

Ornamenting of altars is mostly attended with plants cultivated in homegardens. Due to the scarcity of copal and other plants used in ceremonies, people practice gathering them in different sites throughout their territory (Tables 5 and 6). In addition, we recorded storing of copal resin for use throughout the year (Table 5).

Several species considered scarce in the wild are, however, enough for satisfying the needs of the community; this is particularly the case of Tillandsia grandis (Table 5). The availability of useful plants depends on seasonality, annual rainfall, and incidence of pests (Tables 5 and 6).

Gathering was the only practice for 28 ornamental species (Table 3); species used for ornamenting the altars are gathered by women in areas close to the village, but plants used in communitarian celebrations, as well as the resin of Bursera spp., are carried out by men (Table 5). Journeys for gathering these products may take several hours or days and are considered dangerous activities, particularly those to obtain Beaucarnea stricta, T. grandis, and Burmannia biflora (Table 6). For the extraction of these plants, several techniques are common to prevent damage, such as leaving stems and main branches of the most valuable species (orchids, $B$. biflora, B. stricta, C. alba, and L. glaucescens). These techniques favor survival and resprouting of plants (Table 6). In total, 22 species that germinate and 
Table 5 Sociocultural parameters estimated for species considered in in-depth studies

\begin{tabular}{|c|c|c|c|c|c|c|c|c|c|c|c|c|c|}
\hline$\overline{\mathrm{ID}}$ & Species & Us & SIB & SIU & Con & UF & Var & El & $\mathrm{Rl}$ & SCS & UP $\mathrm{P}^{\mathrm{a}}$ & $\mathrm{HEf}^{\mathrm{a}}$ & $\mathrm{HTO}^{\mathrm{a}}$ \\
\hline \multicolumn{14}{|c|}{ Ceremonial } \\
\hline Bbif & Bursera biflora (Rose) Standl. & 7 & 0 & 0.028 & 1 & 5 & 1 & 1,3 & $1,2,3$ & $1,2,3,6$ & 4 & 3 & 9 \\
\hline Blon & Bouvardia longiflora (Cav.) Kunth & 1 & 0 & 0.006 & 0.01 & 3 & 0 & 1 & 1 & 0 & 2 & 1 & 1 \\
\hline Bstr & Beaucarnea stricta Lem. & 2 & 0.005 & 0 & 1 & 4 & 0 & 1 & $1,2,3$ & 1 & 1 & 2 & 4 \\
\hline Calb & Chiococca alba (L.) Hitchc. & 3 & 0.002 & 0.066 & 0.99 & 4 & 0 & 1 & 1,2 & 0 & 2 & 1 & 0 \\
\hline Dser & Dasylirion serratifolium (Karw. ex Schult. \& Schult.f.) Zucc. & 5 & 0.010 & 0 & 1 & 4 & 2 & 1 & $1,2,3$ & 1 & 2 & 3 & 7 \\
\hline Dspp & Dahlia apiculata (Sherff) P.D.Sorensen; Dahlia coccinea Cav. & 2 & 0 & 0 & 0.12 & 4 & 1 & 1 & 1 & 0 & 2 & 1 & 1 \\
\hline Ekar & Euchile karwinskii (Mart.) Christenson & 3 & 0.002 & 0.033 & 0.99 & 3.5 & 0 & 1 & 1,3 & 0 & 2 & 3 & 5 \\
\hline Erad & $\begin{array}{l}\text { Epidendrum radioferens (Ames, F.T.Hubb. \& C.Schweinf.) } \\
\text { Hágsater }\end{array}$ & 2 & 0.002 & 0 & 0.85 & 3 & 0 & 1 & 1,3 & 0 & 3 & 1 & 1 \\
\hline Lalb & Laelia albida Bateman ex Lindl. & 2 & 0.002 & 0.052 & 0.77 & 4 & 0 & 1 & 1,3 & 0 & 2 & 1 & 2 \\
\hline Ldas & Lamourouxia dasyantha (Cham. \& Schltdl.) W.R.Ernst & 2 & 0 & 0.039 & 0.17 & 3 & 2 & 1 & 1,2 & 0,2 & 2 & 1 & 3 \\
\hline Lgla & Litsea glaucescens Kunth & 3 & 0.010 & 0 & 1 & 6 & 0 & 1 & $1,2,3$ & 3,4 & 1 & 3 & 3 \\
\hline Lmes & Lindleya mespiloides Kunth & 2 & 0 & 0.015 & 0.05 & 4 & 0 & 1 & 1,2 & 0,2 & 2 & 1 & 1 \\
\hline Mdep & Meteorium deppei (Hornsch. ex Müll. Hal.) Mitt. & 2 & 0 & 0 & 1 & 4 & 1 & 1 & 3 & 0,2 & 1 & 2 & 6 \\
\hline Octa & "Octavillo" & 2 & 0 & 0.025 & 0.01 & 2 & 0 & 1 & 1,2 & $0,1,2$ & 1 & 2 & 3 \\
\hline Prub & Plumeria rubra L. & 2 & 0 & 0.007 & 0.05 & 2 & 2 & 1,3 & 1 & 0 & 2 & 3 & 3 \\
\hline Rmac & Rhynchostele maculate (Lex.) Soto Arenas \& Salazar & 2 & 0.002 & 0.005 & 0.92 & 2 & 0 & 1 & 1,3 & 1 & 2 & 3 & 5 \\
\hline Spur & Salvia purpurea Cav. & 3 & 0 & 0.016 & 0.05 & 3.3 & 2 & 1 & 1 & 0 & 2 & 1 & 1 \\
\hline Tgra & Tillandsia grandis Schltdl. & 2 & 0 & 0.009 & 1 & 5 & 0 & 1 & 3 & 1 & 1 & 2 & 9 \\
\hline Tluc & Tagetes lucida Cav. & 4 & 0.003 & 0.007 & 0.5 & 1 & 0 & 1 & 1,2 & 0,3 & 2 & 1 & 1 \\
\hline Tusn & Tillandsia usneoides (L.) L. & 5 & 0 & 0 & 1 & 3 & 0 & 1 & 1 & 0,2 & 1 & 1 & 1 \\
\hline \multicolumn{14}{|l|}{ Edible } \\
\hline Acris & Anoda cristata (L.) Schltdl. & 4 & 0 & 0.012 & 0.05 & 2 & 0 & 1 & 1 & 0 & 3 & 2 & 1 \\
\hline Ahyb & Amaranthus hybridus $\mathrm{L}$. & 3 & 0.024 & 0.252 & 0.95 & 4.5 & 3 & 1,3 & 1,2 & 4 & 1 & 3 & 1 \\
\hline Aker & Agave kerchovei Lem. & 4 & 0 & 0.015 & 0.2 & 3 & 0 & 1 & 1 & 0,1 & 3 & 3 & 4 \\
\hline Apot & Agave potatorum Zucc. & 8 & 0.057 & 0.072 & 0.25 & 3.5 & 2 & $1,2,3,4$ & $1,2,3$ & $1,4,6$ & 5 & 3 & 7 \\
\hline Bdul & Brahea dulcis (Kunth) Mart. & 11 & 0.106 & 0.002 & 1 & 2 & 0 & $1,2,3,4$ & 1,3 & $1,3,6$ & 5 & 3 & 7 \\
\hline Cber & Chenopodium berlandieri Moq. & 2 & 0.006 & 0.022 & 0.15 & 3 & 3 & 1 & 1,2 & 0 & 1 & 3 & 1 \\
\hline Crme & Crataegus mexicana Moc. \& Sess, ex DC & 1 & 0.002 & 0.011 & 0.35 & 4 & 3 & $1,2,3$ & 1,2 & $0,1,2,3,6$ & 1 & 2 & 1 \\
\hline Damb & Dysphania ambrosioides (L.) Mosyakin \& Clemants & 3 & 0.065 & 0.024 & 1 & 6 & 3 & 1,3 & 1,2 & $3,4,6$ & 2 & 2 & 1 \\
\hline Dser & Dasylirion serratifolium (Karw. ex Schult. \& Schult.f.) Zucc. & 5 & 0.010 & 0.110 & 0.95 & 4 & 2 & 1 & $1,2,3$ & 0,1 & 2 & 3 & 7 \\
\hline Lgla & Litsea glaucescens Kunth & 3 & 0.010 & 0.026 & 0.14 & 3.5 & 0 & 1 & $1,2,3$ & 3,4 & 1 & 3 & 3 \\
\hline Lspp & Lantana camara L.; L. velutina M.Martens \& Galeotti & 5 & 0 & 0 & 0.05 & 4.5 & 1 & 1 & 1 & 0 & 2 & 1 & 1 \\
\hline Mspp & Mammillaria haageana Pfeiff.; Mammillaria sphacelata Mart. & 3 & 0 & 0 & 0.05 & 3.3 & 1 & 1 & 1,2 & 0 & 2 & 1 & 1 \\
\hline Noff & Nasturtium officinale R.Br. & 1 & 0.002 & 0.013 & 0.15 & 2.5 & 0 & 1 & 1 & 0 & 1 & 1 & 1 \\
\hline Olas & Opuntia lasiacantha Pfeiff. & 6 & 0.042 & 0.043 & 1 & 6 & 3 & 1,3 & 1,2 & $1,2,4,6$ & 5 & 3 & 5 \\
\hline Ospp & Oxalis aff. latifolia Kunth; Oxalis aff. nelsonii (Small) R.Knuth & 2 & 0 & 0.007 & 0.45 & 3 & 1 & 1,3 & 1,2 & 0 & 1 & 3 & 1 \\
\hline Plin & Porophyllum linaria (Cav.) DC. & 2 & 0 & 0.078 & 0.95 & 6 & 0 & 1,3 & 1,2 & 4,6 & 3 & 1 & 1 \\
\hline Pole & Portulaca oleracea L. & 3 & 0 & 0.010 & 0.05 & 4 & 0 & 1 & 1 & 0 & 1 & 3 & 1 \\
\hline Pphi & Physalis philadelphica Lam. & 2 & 0 & 0.015 & 1 & 6 & 3 & $1,2,3$ & 1,3 & $2,3,5,6$ & 1 & 3 & 1 \\
\hline Pqua & Peperomia quadrifolia (L.) Kunth & 2 & 0.014 & 0.070 & 0.95 & 4 & 3 & 1 & 1,2 & 0 & 1 & 3 & 1 \\
\hline Prud & Porophyllum ruderale subsp. macrocephalum (DC.) R.R.Johnson & 1 & 0.004 & 0.161 & 0.9 & 5 & 0 & 1,3 & 1,2 & 0 & 1 & 1 & 1 \\
\hline
\end{tabular}


Table 5 Sociocultural parameters estimated for species considered in in-depth studies (Continued)

\begin{tabular}{|c|c|c|c|c|c|c|c|c|c|c|c|c|c|}
\hline ID & Species & Us & $\mathrm{SIB}$ & SIU & Con & UF & Var & El & $\mathrm{Rl}$ & SCS & $U P^{a}$ & HEf ${ }^{a}$ & $\mathrm{HTo}^{\mathrm{a}}$ \\
\hline \multicolumn{14}{|l|}{ Medicinal } \\
\hline Amai & Ageratina mairetiana (DC.) R.M.King \& H.Rob. & 3 & 0.014 & 0.150 & 0.85 & 2 & 2 & 1 & 1,2 & $1,3,4$ & 3 & 3 & 1 \\
\hline Apsi & Ambrosia psilostachya DC. & 1 & 0 & 0.032 & 0.85 & 2.5 & 0 & 1 & 1,2 & $1,2,3,4$ & 1 & 3 & 1 \\
\hline Bsal & Barkleyanthus salicifolius (Kunth) H.Rob. \& Brettell & 6 & 0.003 & 0.029 & 0.85 & 3 & 0 & 1 & 1,2 & 4 & 3 & 2 & 3 \\
\hline Clme & Clinopodium mexicanum (Benth.) Govaerts & 2 & 0 & 0.136 & 0.85 & 4 & 0 & 1 & 1,2 & $1,3,4$ & 2 & 3 & 1 \\
\hline Cmex & Chrysactinia mexicana A.Gray & 1 & 0 & 0.017 & 0.85 & 3.5 & 0 & 1 & 1,2 & $1,3,4$ & 3 & 3 & 1 \\
\hline Dcar & Dalea carthagenensis (Jacq.) J.F.Macbr. & 2 & 0 & 0.010 & 0.85 & 2.5 & 0 & 1 & 1 & 0 & 1 & 3 & 1 \\
\hline Gglu & Gymnosperma glutinosum (Spreng.) Less. & 3 & 0.002 & 0.031 & 0.85 & 0.5 & 0 & 1 & 1 & 0 & 1 & 2 & 0 \\
\hline Ginu & Grindelia inuloides Willd. & 1 & 0.029 & 0.094 & 0.85 & 2.5 & 0 & 1 & 1,2 & $1,2,3,4$ & 1 & 3 & 1 \\
\hline Loax & Lippia oaxacana B.L.Rob. \& Greenm. & 2 & 0.014 & 0.264 & 0.85 & 3.5 & 0 & 1 & 1,2 & $1,3,4$ & 1 & 3 & 1 \\
\hline Mpar & Malva parviflora $\mathrm{L}$. & 3 & 0 & 0.032 & 0.85 & 3.5 & 0 & 1 & 1,2 & 0 & 3 & 2 & 1 \\
\hline Mpur & Matelea purpusii Woodson & 2 & 0 & 0.015 & 0.85 & 3.5 & 0 & 1 & 1,2 & 0 & 2 & 3 & 1 \\
\hline Mvul & Marrubium vulgare L. & 1 & 0 & 0.056 & 0.85 & 3 & 0 & 1 & 1,2 & 0 & 1 & 2 & 1 \\
\hline Ppen & Parietaria pensylvanica Muhl. ex Willd. & 1 & 0 & 0.016 & 0.85 & 1 & 0 & 1 & 1,2 & 0,2 & 1 & 2 & 1 \\
\hline Pros & Pinaropappus roseus (Less.) Less. & 1 & 0 & 0.012 & 0.85 & 1 & 0 & 1 & 1 & 0 & 3 & 1 & 1 \\
\hline Rcom & Ricinus communis L. & 4 & 0 & 0.016 & 0.85 & 3 & 3 & 1 & 1,2 & 0 & 2 & 2 & 1 \\
\hline Spra & Senecio praecox (Cav.) DC. & 3 & 0 & 0.009 & 0.85 & 1 & 0 & 1 & 1,2 & 3,4 & 2 & 3 & 1 \\
\hline Tdif & Turnera diffusa Willd. ex Schult. & 2 & 0 & 0.037 & 0.85 & 2 & 0 & 1 & 1,2 & 3 & 1 & 1 & 1 \\
\hline Tluc & Tagetes lucida Cav. & 4 & 0.003 & 0.052 & 0.85 & 4.5 & 0 & 1 & 1,2 & 0,3 & 2 & 1 & 1 \\
\hline Apot & Agave potatorum Zucc. ${ }^{a}$ & 8 & 0.057 & 0.039 & 0.85 & 2 & 2 & $1,2,3,4$ & $1,2,3$ & $1,4,6$ & 5 & 3 & 7 \\
\hline Qacu & Quercus acutifolia Née ${ }^{a}$ & 7 & 0.072 & 0.010 & 0.85 & 1 & 1 & 1,3 & 1,3 & 0,2 & 4 & 2 & 11 \\
\hline
\end{tabular}

ID identification tag assigned to the species analyzed, US uses number, SIB Sutrop index for plants considered basic to life, SIU Sutrop index by use type, Con consumption, UF use frequency, Var recognized variants, El economic interchange, RI reciprocity interchange, SCS sociocultural strategies, UP useful parts, HEf harvest effort, HTo tools used for harvest

${ }^{a}$ Excluded variables and species in the performance of principal component analyses (PCA) and canonical correspondence analyses

become spontaneously established in AFS are tolerated and their abundance enhanced, by leaving plants producing seeds or deliberately dispersing seeds in sites propitious for their growth (Tables 3 and 7). About 38 species receive special care such as irrigation, addition of organic matter, control of pests, and removal of competitors (Tables 3 and 7). Transplanting of juvenile plants of 26 species and propagation of 19 species is conducted with the purpose of having them closer to homes (mainly homegardens) in order to enjoy their beauty, having available their flowers, satisfying their curiosity to know how plants grow, and experimenting horticultural practices (Tables 3 and 6). We recorded experiments of in situ vegetative propagation of $B$. biflora and transplanting of several species of orchids and Bromeliaceae species (Tables 6 and 7). We in addition documented reasons why local people do not practice management. They consider unviable planting plants that are abundant or have special requirements and low probability of survival or those for whom they do not have information about plants' requirements to survive and grow (Table 6) or when people have limitations of space for maintaining plants.
Selective harvesting of plants based on use quality of their parts and absence of signs of herbivory are criteria for gathering most species documented. Although local people recognize at least five species with intraspecific varieties (identified according to flower color and forms), their use and management are indistinct (Tables 5 and 7). Except for Tagetes erecta, in which people select seeds for cultivation, and Cosmos bipinnatus, a species commonly producing violaceus ligula, people select the scarcer variety with white ligula.

Local regulations forbid extraction of plants for commercialization out of the village and establish restrictions in using some plants in communitarian celebrations (Table 7).

\section{Edible plants}

We recorded 138 plant species used as food, 80 of them being wild and naturalized species and 20 considered as "basic" (Tables 3 and 4). The most valuable species are Amaranthus hybridus, Porophyllum spp., Opuntia lasiacantha, Dysphania ambrosioides, Dasylirion serratifolium, Peperomia quadrifolia, and Physalis philadelphica, which are consumed by more than $90 \%$ of households from 1 to 
Table 6 Meaningful consultant's commentaries about the use, abundance, and their motives to manage plants

\begin{tabular}{lll}
\hline Use & ID & Species \\
\hline Ceremonial & Bbif & Bursera biflora (Rose) Standl. \\
& \\
Ceremonial & Blon & Bouvardia longiflora (Cav.) Kunth \\
Ceremonial & Bstr & Beaucarnea stricta Lem.
\end{tabular}

Ceremonial Calb Chiococca alba (L.) Hitchc.

Ceremonial Dser Dasylirion serratifolium (Karw. ex Schult. \& Schult.f.) Zucc.

Ceremonial Dspp

Dahlia apiculata (Sherff) P.D.Sorensen; Dahlia coccinea Cav.

Ceremonial Ekar Euchile karwinskii (Mart.) Christenson

Ceremonial Erad Epidendrum radioferens (Ames, F.T.Hubb. \& C.Schweinf.) Hágsater

$\begin{array}{lll}\text { Ceremonial } & \text { Lalb } & \text { Laelia albida Bateman ex Lindl. } \\ \text { Ceremonial } & \text { Ldas } & \text { Lamourouxia dasyantha (Cham. \& Schltdl.) } \\ & \text { W.R.Ernst } \\ \text { Ceremonial } & \text { Lgla } & \text { Litsea glaucescens Kunth }\end{array}$

$\begin{array}{lll}\text { Ceremonial Lmes } & \text { Lindleya mespiloides Kunth } \\ \text { Ceremonial } & \text { Mdep } & \text { Meteorium deppei (Hornsch. ex Müll. Hal.) Mitt. } \\ \text { Ceremonial } & \text { Octa } & \text { "Octavillo" }\end{array}$

Management motives and observations about use and availability

Trees are abundant, but copal could becomes scarce.

Care should be taken to not damage the tree, to tree continue producing the copal.

Only the one produced naturally, by the worm [butterfly larvae] in hot terrain is good for burning.

Not [transplant or cultivation] because the tree would not survive or produce copal here in the village.

I have a little tree that I take out of the forest for the luxury of my house and I hope that someday it will produce copal, although maybe it would not be enough or good. I plant a stick, there in the mountain where I go to collect the "copal", I did to see if it [roots].

Now it is almost no longer used, there are other flowers [flowers of introduced species].

The gathering is dangerous, the plant is in very difficult places to walk.

Care must be taken to not injure the tree, the [apical meristem], so that the plant continues to produce, sometimes the tree is damaged, but that should not be done.

Before it was used [to offer it] in the church, but now no longer because they criticize, only is placed on the altars of the houses. I really like its flowers, its scent, I put it on my altar.

Once I brought a little tree to the house but It do not survive. Out of curiosity I try to [cultivate], but it does not [germinate].

It should leave part of the trunk, if there is good rain it can sprout. It has not occurred to us to bring the plant to the village, "it is natural" [it occurs naturally in the field], we always have found it to make the adornments.

I like to have them in the house, for luxury [ornamental use] and put the flowers on the altar.

It must remain [peudobulbs] to have it for another time, they are the ornament of the trees [in the forest].

After the flower dries, the (pseudobulb] is placed in some tree in the house, and so it is going to have for luxury [ornamental use] and have flowers to adornment the altar.

When I am gathering firewood and I cut a branch that have "monjitas" [orchids], sometimes I transplant it in other branch and sometimes I bring it to the house.

It must remain [peudobulbs] to have it for another time.

They are the ornament of the trees [in the forest].

After the flower dries, is placed in some tree in the house, and so it is going to have for luxury [ornamental use] and have flowers to adornment the altar, however it is difficult, it is a delicate plant.

I take care it [cultivation] to have flowers for the altar in Todos Santos [celebration] and for the luxury of my home.

There is much when rain is good, but when it is not given, I use whatever available flower.

There is a lot in the forest, there is always when it is needed and the tree will regrow if you do not hurt it.

I have not had the curiosity [transplanting] and the need because there is [enough], and there is also little terrain to have it maybe it will dry.

Out of curiosity, I put some seeds but they did not germinate.

There is a lot in the forest, but sometimes there are no flowers due to the drought.

After the celebration, I put it in my yard for luxury, but it dried.

I have always found when I am going to collect, but sometimes, in order to not go up to the mountain, I better buy others [other plants in regional markets].

I think it would not survive [transplanting, cultivation], is a delicate plant and its environment is very different, more template. 
Table 6 Meaningful consultant's commentaries about the use, abundance, and their motives to manage plants (Continued)

\begin{tabular}{lll}
\hline Use & ID & Species \\
\hline Ceremonial & Prub & Plumeria rubra L. \\
Ceremonial & Rmac & $\begin{array}{l}\text { Rhynchostele maculate (Lex.) Soto Arenas \& } \\
\text { Salazar }\end{array}$
\end{tabular}
Salazar

$\begin{array}{lll}\text { Ceremonial } & \text { Spur } & \text { Salvia purpurea Cav. } \\ \text { Ceremonial } & \text { Tgra } & \text { Tillandsia grandis Schltdl. } \\ \text { Ceremonial } & \text { Tluc } & \text { Tagetes lucida Cav. } \\ \text { Ceremonial } & \text { Tusn } & \text { Tillandsia usneoides (L.) L. } \\ & & \\ \text { Edible } & \text { Acris } & \text { Anoda cristata (L.) Schltdl. } \\ & & \\ \text { Edible } & \text { Ahyb } & \text { Amaranthus hybridus L. }\end{array}$

Edible

Agave kerchovei Lem.

Edible

Agave potatorum Zucc.

Edible

Brahea dulcis (Kunth) Mart.

Edible
Management motives and observations about use and availability

I have not tried [propagation], I have not had the curiosity, I like it a lot but I do not try to have it, but there are people that have it. I plant a stick to have the tree here in the house, but it rotted, maybe I try again later.

It must remain [peudobulbs] to have it for another time. They are the ornament of the trees [in the forest]. After the flower dries, the [pseudobulb] is placed in some tree in the house, and so it is going to have for luxury [ornamental use] and have flowers to adornment the altar.

It is difficult take care of it because it is delicate, but it is a pride to have it.

Used more before. There is much when rain is good, but when it is not given, I use whatever available flower, now there are other flowers [introduced that are grown or bought in local stores]. Once I take one from the mountain, to have the flowers for my altar and luxury of the house, but it dried and I have not tried again.

There has always been when it is needed.

Once I brought some small plants [transplanting] but dried, is very delicate, needs its natural environment.

There is much when rain is good, but when it is not given, I use whatever available flower.

I have this plant, I bring it from the mountain and from the adornment of holidays, it is for decoration of my trees and also to feed the cattle when there is nothing, to clean the frets, for what is could needed here I got it near, in my house.

Before the people collected it, they gathered. Now it is scarce and people say that who eats it does not have money to buy food.

It is very tasty, it is important to eat it, but it is left to the time and the rain, there has been no need to cultivate it, it is only left on the edge of the cropland to produce seed.

There are different colors but if it is "tierno" [shoots] taste does not change, but others prefer the green.

When there are a lot and is "sazón" [mature] it could damage the other plants so it is plucked.

People say that when someone eats "cacayas" [floral buttons] it's because they do not have money for food, but we like it. Only is gathered, it is close, it is not necessary to propagate it.

This "cacaya" was eaten a lot, was eaten boiled with sauce when there was nothing else or when corn was scarce it was mixed with the nixtamal [boiled corn] to raise it to make the tortillas.

When we cooked maguey with coyule [Oxalis spp.] we gave to friends and relatives and other part is for sell it.

Now people have it in their fields for mescal, but it was getting scarce, now they are sowing it [mescal producers and external institutions].

Its leaf and thorns vary in shape and color, its size is different, ones gives more mescal, although we like it to be large we cut everything.

When we collect seed for [cultivate] it, we go to sites where we know the maguey is big and produce more mescal, others only get the first [capsules with seeds] available.

When a field is opened [for agriculture], the palm is left, it is our sustenance, the hat.

I do not wave the hat but my neighbors do it, is the sustenance of the town, it is the motive because I left it in my terrain [tolerance].

Abundance: Before there was more because they no longer work the land as the older.

On the edge of the land some are left (tolerated) to produce seeds and there are for the next year. 
Table 6 Meaningful consultant's commentaries about the use, abundance, and their motives to manage plants (Continued)

\begin{tabular}{|c|c|c|}
\hline Use & ID & Species \\
\hline Edible & Crme & Crataegus mexicana Moc. \& Sess, ex DC \\
\hline Edible & Damb & $\begin{array}{l}\text { Dysphania ambrosioides (L.) Mosyakin \& } \\
\text { Clemants }\end{array}$ \\
\hline Edible & Dser & $\begin{array}{l}\text { Dasylirion serratifolium (Karw. ex Schult. \& } \\
\text { Schult.f.) Zucc. }\end{array}$ \\
\hline Edible & Lgla & Litsea glaucescens Kunth \\
\hline Edible & Lspp & $\begin{array}{l}\text { Lantana camara L.; L. velutina M.Martens \& } \\
\text { Galeotti }\end{array}$ \\
\hline Edible & Mspp & $\begin{array}{l}\text { Mammillaria haageana Pfeiff.; Mammillaria } \\
\text { sphacelata Mart. }\end{array}$ \\
\hline Edible & Noff & Nasturtium officinale R.Br. \\
\hline Edible & Olas & Opuntia lasiacantha Pfeiff. \\
\hline
\end{tabular}

$\begin{array}{lll}\text { Edible } & \text { Ospp } & \begin{array}{l}\text { Oxalis aff. latifolia Kunth; Oxalis aff. nelsonii } \\ \text { (Small) R.Knuth) }\end{array} \\ \text { Edible } & \text { Plin } & \text { Porophyllum linaria (Cav.) DC. } \\ \text { Edible } & \text { Pole } & \text { Portulaca oleracea L. } \\ \text { Edible } & \text { Pphi } & \text { Physalis philadelphica Lam. }\end{array}$
Management motives and observations about use and availability Before there were more, now no one cares for them, the animals eat [cattle].

There are with large and small fruit, with sweet and sour taste. I tried to [propagates] but it does not [germinate].

Sometimes my neighbor and my aunt ask me for some of it and as I have, I give them a little. I saw a little plant that I liked for its large and green leaves and brought it to my house, I take care of it and now I have all the time.

There are green, purple and "criollo" (from the store), the last does not have smell, nor taste.

Although the plant is abundant, the "manita" [Floral buttons ] becomes scarce because of the drought, when that happens we were left with the desire to eat it that year.

It has not occurred to me to take the "manita" plant to the village, "it is natural".

There are green "manitas" that are sweet and purples that are bitter, but at the whim we eat the same two.

For food it requires little, a few twigs.

I have not had the curiosity, the need [propagation], I only go to the field and collect it.

Out of curiosity, I put some seeds but they did not germinate.

They eat it when they go to the field, but they are not sweet, they are simple.

I brought one to my house for luxury, not to eat the "chilitos" [fruits], I like the way it looks.

It is no longer consumed because there is no one who collects it. When harvested, the root must be left to it could sprout.

As I have many plants I always have, I give it to my family when they ask me and sometimes other people come to ask me, sometimes I give them and others I sell it depending on how much it is.

I brought a "penquita" [cladode] and now all those who fall and take root I care of them because it is the "nopal" that I like, those that come from outside are not good.

There are some more spiny than others and they give "tunas" [fruits] of different color.

I brought this [Oxalis plant] out of curiosity, for luxury of the house [ornamental], when we want make the "conserva" [Traditional dish prepared with Agave potatorum stems and Oxalis leaves] we go to the mountain where it grow big.

Its left on the edge of the cropland to produce seed. Some people have had the curiosity to cultivate it, they have it all the time, sometimes they give me a little.

I only like the plants that I have inside of the "corralito" [space inside the yard delimited by a fence] or that are in crop lands, it is abundant in roads and the yard but is nasty by the animals.

I leave some plants to flower and give seed to have in abundance next year, although when it is a lot it is plucked.

Last year was good [good production], it reach to give 6 kilos to my brothers who live outside

It is abundant, but it is because we take care of it. I leave some [fruits] so that the next year can continue, in homegardens is watered, fertilized, so that they can produce [fruits].

There is "milomate" of the maize crop land, "dulce" (sweet) from the wheat cropland and one big that we get in the store, the last one is not so good and to have [manage and cultivate] we choose the miltomate and the sweet, of which it is pretty [big]. 
Table 6 Meaningful consultant's commentaries about the use, abundance, and their motives to manage plants (Continued)

\begin{tabular}{lll}
\hline Use & ID & Species \\
\hline Edible & Pqua & Peperomia quadrifolia (L.) Kunth \\
& \\
Edible & Prud & $\begin{array}{l}\text { Porophyllum ruderale subsp. macrocephalum } \\
\text { (DC.) R.R.Johnson }\end{array}$
\end{tabular}

Medicinal Amai Ageratina mairetiana (DC.) R.M.King \& H.Rob.

Medicinal Apsi Ambrosia psilostachya DC.

Medicinal Bsal Barkleyanthus salicifolius (Kunth) H.Rob. \& Brettell

Medicinal Clme Clinopodium mexicanum (Benth.) Govaerts

Medicinal Cmex Chrysactinia mexicana A.Gray

$\begin{array}{lll}\text { Medicinal } & \text { Dcar } & \text { Dalea carthagenensis (Jacq.) J.F.Macbr. } \\ \text { Medicinal } & \text { Gglu } & \text { Gymnosperma glutinosum (Spreng.) Less. } \\ \text { Medicinal } & \text { Ginu } & \text { Grindelia inuloides Willd. }\end{array}$

Medicinal Loax Lippia oaxacana B.L.Rob. \& Greenm.
Management motives and observations about use and availability

Now that we are old and we can not go to the mountain, we just eat it when my son-in-law shares us.

There is, but it is retired, in rains it is more [juicy].

The one from Gandudo is more tastier.

Somebody brought to have here, but it dries, here is not their environment.

I have not had the curiosity to sow it, but there are some people who have it in their homes, they take care of it and have to eat all the year.

When it is collected only the tender twigs should be cut so that it continues to sprout.

Only the twigs are cut, the rest is left and thus sprouts. Only the twigs are cut, if everything is harvested, it runs out. When there is one in the house or the agricultural field, is [tolerated].

In the harvest, the twigs are cut and the stem is left so it can sprout.

We do not bring it to the house because we do not know if it will survive, we do not know what it need to produce.

We store it because there is no in dry season.

Before, many people had it in their homes, now they do not like it so much. It is easy to have it, does not need care as fertilizer or irrigation.

I have it, because when it is needed, I only go to the yard, besides it's luxury [ornamental] for my house.

It is not necessary to cut all the plant, only the twigs, leaving the stem can sprout and continues [be available].

I always have dry, it is more to drink, because it is almost not used as medicine.

For medicine, it is collected when it's needed, is not necessary to bring it [to the houses].

Here [mescal factory] it is natural [natural distribution], we only take care of it when is harvested and that the animals (cattle) do not foraged it.

I have not tried to bring it to the house, but if I would do it, it could be, to do not have to go by it, although I do not know if it could survive.

I always have some of this plant, I let it dry and I keep it for when it is needed, when I go to the field and there are, I gather it, so I always have.

When I need it and I do not have it stored, I ask someone to give me a little.

This is no longer used so much, but when I need it I'm going to gather it to the edge of town or somebody brings it to me

There is much everywhere, you only have to gather it when do you need it.

There are those who have it (managed in the houses or dry), when it is needed, we asks them for it or we are going to look for it to field. I think it is not difficult, but maybe the soil did not help to survival of the one that I tries to propagate.

Only the twigs are cut so that it can sprout.

When drying this plant does not lose its quality, it is very strong.

We store it so we can have it when we need it.

I worry that there is not [available when its needed], but I do not bring seedlings to the house because if I bring them and they dry, I will only run out them.

I brought a little plant but it dried.

I leave some plants on the edge to have it, but when there is a lot, it must be rooted out.

I brought it to my house because I'm [need it], so I always have it here. 
Table 6 Meaningful consultant's commentaries about the use, abundance, and their motives to manage plants (Continued)

\begin{tabular}{|c|c|c|c|}
\hline Use & ID & Species & Management motives and observations about use and availability \\
\hline Medicinal & Mvul & Marrubium vulgare $\mathrm{L}$. & $\begin{array}{l}\text { Is very resistant, while more you cut, more there are. I leave some } \\
\text { plants on the edge to have it, but when there is a lot, it must be } \\
\text { rooted out. }\end{array}$ \\
\hline Medicinal & Ppen & Parietaria pensylvanica Muhl. ex Willd. & $\begin{array}{l}\text { There are at the edge of the village, in my house I leave them in } \\
\text { case that someday I would need it. }\end{array}$ \\
\hline Medicinal & Pros & Pinaropappus roseus (Less.) Less. & $\begin{array}{l}\text { Before it was used when it was at hand, there are others that are } \\
\text { used for [the same]. }\end{array}$ \\
\hline Medicinal & Rcom & Ricinus communis L. & $\begin{array}{l}\text { I have of the two [green and red] each one has its use, they are } \\
\text { also luxury [ornamental]. } \\
\text { I brought the first from the road, I transplant the [seedlings] and } \\
\text { take care of them, there are those who have taken the seed of } \\
\text { those that they need to sow it. When they are abundant, they } \\
\text { have to be rooted out. }\end{array}$ \\
\hline Medicinal & Spra & Senecio praecox (Cav.) DC. & $\begin{array}{l}\text { Now little is used, before it was stored, now only a few use it. } \\
\text { I brought a little plant, out of curiosity, now it is luxury of my } \\
\text { house [ornamental] and by the time I need it I have it at hand. }\end{array}$ \\
\hline Medicinal & Tdif & Turnera diffusa Willd. ex Schult. & $\begin{array}{l}\text { When drying this plant does not lose its quality, it is very strong. } \\
\text { When I need it and I do not have it stored, I ask someone to give } \\
\text { me a little. }\end{array}$ \\
\hline Medicinal & Tluc & Tagetes lucida Cav. & $\begin{array}{l}\text { I always have dry for when it is needed, this plant does not lose its } \\
\text { quality when is drying, it is very strong. } \\
\text { If part of the stem is left it can sprout, it must be left to continue } \\
\text { [be abundant]. }\end{array}$ \\
\hline Medicinal & $\operatorname{Apot}^{a}$ & Agave potatorum Zucc. & $\begin{array}{l}\text { Now few cooked the "conserva" [maguey stem cooked with Oxalis } \\
\text { spp. leaves], but when they do it, they share it with their friends or } \\
\text { they also sell it. } \\
\text { The cacayas are eaten [flowers] when we meet one while walking } \\
\text { in the field, to make mescal we have to go especially to cut the } \\
\text { maguey and sometimes we have to buy it to other communities. } \\
\text { Now there is scarce before there was here on the shore, now we } \\
\text { have to walk to find, about three hours or more to [prepare] the } \\
\text { mescal. } \\
\text { Now [governmental] programs bring the maguey, we plant them } \\
\text { in the fields and some [mescal producers] are already producing } \\
\text { the plant, but it still lacks [time] to have it again. }\end{array}$ \\
\hline Medicinal & $\mathrm{Qacu}^{\mathrm{a}}$ & Quercus acutifolia Née & $\begin{array}{l}\text { When needed [for medicinal use] we look for it, just a few } \\
\text { branches with tender leaves. } \\
\text { It is also widely used by firewood. } \\
\text { For wood, trees should not cut only the branches. } \\
\text { I have two little trees, I brought acorns to feed my animals, but I } \\
\text { leave some because I like these plants, but it is difficult they are } \\
\text { delicate they hardly [germinate or survive], it takes a lot of } \\
\text { patience and a lot of cares. }\end{array}$ \\
\hline
\end{tabular}

${ }^{\mathrm{a} E x c l u d e d}$ variables and species in the performance of principal component analyses (PCA) and canonical correspondence analyses

10 times per season (Fig. 2, Table 5). About 40 species are occasionally consumed where they are gathered and rarely carried to homes. These are the cases of Chrysactinia mexicana and Cyrtocarpa procera. Other 30 species are consumed occasionally, but it is considered that most of them were highly consumed in the past; these are the cases of Chenopodium spp., Anoda cristata, Nasturtium officinale, Agave kerchovei, and A. potatorum. Consumption of these plants has decreased due to higher presence of cultivated and processed food (Table 6). Other species are consumed occasionally by few households, as is the case of L. glaucescens which is used as a condiment or Tagetes lucida, Lippia sp., and Turnera diffusa, which in the past were commonly used as infusions and now were substituted by coffee.
Commercialization of managed weedy plants is allowed, and the most common is the green tomato $P$. philadelphica. Others occasionally commercialized are O. lasiacantha and cooked A. potatorum (Table 5). P. philadelphica, C. mexicana, Porophyllum spp., and D. ambrosioides are interchanged in local stores (Table 5). Local people share with relatives and friends part of the plants gathered or harvested (Tables 5 and 6). These are the cases of D. serratifolium, P. quadrifolia, C. mexicana, P. philadelphica, D. ambrosioides, Opuntia spp., Porophyllum spp., A. potatorum, and A. hybridus.

Most edible plant species are considered abundant (Table 7), but such abundance is associated with care during extraction or the management in crop fields and 
Table 7 Ecological and management parameters estimated for species considered in in-depth studies

\begin{tabular}{|c|c|c|c|c|c|c|c|c|c|c|c|c|c|}
\hline \multirow[b]{2}{*}{$\mathrm{ID}$} & \multicolumn{5}{|c|}{ Management parameters } & \multirow[b]{2}{*}{$\mathrm{Nea}^{\mathrm{a}}$} & \multirow[b]{2}{*}{$\mathrm{TAv}^{\mathrm{a}}$} & \multicolumn{3}{|c|}{ Management parameters } & \multirow[b]{2}{*}{ MAFS } & \multirow[b]{2}{*}{$\mathrm{MLa}^{\mathrm{a}}$} & \multirow[b]{2}{*}{$\mathrm{MST}^{\mathrm{a}}$} \\
\hline & $\overline{\mathrm{APe}}$ & VEA & $\mathrm{LCi}$ & Rep & $\mathrm{HPa}$ & & & $\overline{\mathrm{CRe}}$ & $\mathrm{MPr}$ & Sel & & & \\
\hline \multicolumn{14}{|c|}{ Ceremonial } \\
\hline Bbif & 4 & 2 & 2 & 2 & $1,1,2,9$ & 1 & 2 & 1 & 2,6 & 0 & 0.05 & 1 & 1,3 \\
\hline Blon & 2 & 2 & 2 & 2 & 5 & 3 & 2 & 0 & 1 & 1 & 0 & 0 & 1 \\
\hline Bstr & 3.3 & 3 & 2 & 2 & 3 & 3.3 & 1 & 1,2 & 2 & 1 & 0 & 0 & 1 \\
\hline Calb & 1.5 & 3.5 & 2 & 2 & 1,5 & 3.5 & 2 & 1 & 2 & 1 & 0 & 0 & 1 \\
\hline Dser & 2 & 2 & 2 & 2 & 8,9 & 4 & 1 & 1,2 & 1,2 & 1 & 0 & 0 & 1 \\
\hline Dspp & 2.5 & 2 & 2 & 1 & 5,9 & 3.5 & 2 & 1 & 2,7 & 1 & 0.17 & 4 & 1,3 \\
\hline Ekar & 3.5 & 2 & 2 & 1 & $1,8,9$ & 1 & 3 & 1 & $1,2,5,6$ & 1 & 0.63 & 1 & 1,3 \\
\hline Erad & 3.5 & 1 & 2 & 1 & $1,8,9$ & 1.5 & 3 & 1 & $1,2,5,6$ & 1 & 0.32 & 1 & 1,3 \\
\hline Lalb & 5 & 2 & 2 & 1 & $1,8,9$ & 1 & 3 & 1 & $1,2,5,7$ & 1 & 1.29 & 1 & 1,3 \\
\hline Ldas & 1.5 & 3 & 2 & 2 & 5 & 3 & 3 & 0 & 1 & 1 & 0 & 0 & 1 \\
\hline Lgla & 2 & 2 & 2 & 2 & 5 & 3.5 & 1 & $1,2,3$ & 2 & 0 & 0 & 0 & 1 \\
\hline Lmes & 2 & 3 & 2 & 2 & 5 & 4 & 3 & 0 & 1 & 1 & 0 & 0 & 1 \\
\hline Mdep & 1 & 1 & 2 & 1 & 10 & 1 & 1 & 0 & 1 & 0 & 0 & 0 & 1 \\
\hline Octa & 3 & 4 & 2 & 2 & 5 & 3 & 1 & 1 & 2 & 1 & 0 & 0 & 1 \\
\hline Prub & 4 & 0 & 2 & 2 & 5 & 1 & 2 & 0 & 1,7 & 1 & 0.10 & 3 & 1,3 \\
\hline Rmac & 3.5 & 2 & 2 & 1 & $1,8,9$ & 1 & 3 & 1 & $1,2,5,6$ & 1 & 0.30 & 1 & 1,3 \\
\hline Spur & 3.5 & 2 & 1 & 2 & 5 & 3 & 3 & 1 & 1,2 & 1 & 0 & 0 & 1 \\
\hline Tgra & 4 & 4 & 2 & 2 & 10 & 2 & 1 & 1 & 1 & 1 & 0 & 0 & 1 \\
\hline Tluc & 2.7 & 2 & 2 & 2 & 9 & 4 & 2 & 0 & 1 & 0 & 0 & 0 & 1 \\
\hline Tusn & 1 & 0 & 2 & 1 & 5,10 & 4 & 1 & 0 & 1,6 & 0 & 1.33 & 1 & 1,3 \\
\hline \multicolumn{14}{|l|}{ Edible } \\
\hline Acris & 2 & 1.5 & 1 & 2 & 4,10 & 4 & 2.5 & 0 & 1,3 & 1 & 0.39 & & 2 \\
\hline Ahyb & 2 & 3 & 1 & 2 & 4,10 & 4 & 2.5 & 1 & $1,2,3,4,5$ & 1,2 & 1.33 & & 2 \\
\hline Aker & 1 & 1.5 & 2 & 1 & $1,1,8$ & 4 & 2 & 0 & $1,3,6$ & 1 & 0.07 & & 1,2 \\
\hline Apot & 2 & 2 & 2 & 2 & $1,1,3,8,10$ & 2.8 & 1 & 1,2 & $1,3,4,5,6,7$ & 1 & 1.16 & & $1,2,3,4$ \\
\hline Bdul & 1 & 2 & 2 & 1 & $1,3,8,9,9$ & 4 & 2 & 1,2 & $1,2,3,5,4,6$ & 1 & 2.01 & & $1,2,3$ \\
\hline Cber & 3 & 3 & 1 & 2 & 4,10 & 4.5 & 2.5 & 0 & $1,3,4$ & 1 & 0.53 & & 2 \\
\hline Crme & 4 & 4 & 2 & 2 & 6 & 2 & 2 & 1 & 2 & 2 & 0.07 & & 1,2 \\
\hline Damb & 2 & 4 & 1 & 2 & 3,4 & 5 & 1.5 & 1 & $2,3,4,5,6,7$ & $1,2,3$ & 0.62 & & 2 \\
\hline Dser & 4 & 2 & 2 & 2 & 8,9 & 3 & 2 & 1,2 & 1,2 & 1 & 0 & & 1 \\
\hline Lgla & 2 & 2 & 2 & 2 & 5 & 3.5 & 1 & $1,2,3$ & 2 & 0 & 0 & & 1 \\
\hline Lspp & 1 & 2 & 2 & 2 & 4,6 & 3.5 & 2 & 0 & $1,3,6$ & 0 & 0.84 & & $1,2,3$ \\
\hline Mspp & 1.5 & 2 & 2 & 1 & 1,6 & 4 & 3 & 0 & $1,3,6$ & 0 & 0.68 & & $1,2,3$ \\
\hline Noff & 3.5 & 1 & 2 & 2 & 4,10 & 4 & 2 & 0 & 1 & 1 & 0 & & 1 \\
\hline Olas & 3 & 3 & 2 & 1 & 4,6 & 5 & 2 & 0 & $1,3,4,5,6,7$ & $1,2,3$ & 0.70 & & $1,2,3$ \\
\hline Ospp & 2 & 2 & 2 & 1 & 3 & 4 & 2 & 0 & $1,3,6$ & 1 & 1.59 & & $1,2,3$ \\
\hline Plin & 1 & 2 & 1 & 2 & 10 & 4.3 & 2 & 0 & $1,3,4,5,6,7$ & 1 & 0.53 & & $1,2,3$ \\
\hline Pole & 2.3 & 0.7 & 1 & 2 & 4,10 & 3.6 & 2 & 0 & $1,3,4,6$ & 1 & 0.30 & & 2 \\
\hline Pphi & 2.5 & 4 & 1 & 2 & 6 & 4.5 & 2 & 0 & $2,3,4,5,6,7$ & $1,2,3$ & 1.97 & & 2 \\
\hline Pqua & 3.5 & 1.5 & 2 & 1 & 9 & 1.5 & 1.5 & 0 & 1 & 1 & 0 & & 1 \\
\hline Prud & 2 & 2 & 2 & 2 & 4 & 4 & 2 & 1 & $2,3,4,5,7$ & 1 & 0.24 & & 1,3 \\
\hline
\end{tabular}


Table 7 Ecological and management parameters estimated for species considered in in-depth studies (Continued)

\begin{tabular}{|c|c|c|c|c|c|c|c|c|c|c|c|c|c|}
\hline \multirow[b]{2}{*}{ ID } & \multicolumn{5}{|c|}{ Management parameters } & \multirow[b]{2}{*}{$\mathrm{Nea}^{\mathrm{a}}$} & \multirow[b]{2}{*}{$\mathrm{TAv}^{\mathrm{a}}$} & \multicolumn{3}{|c|}{ Management parameters } & \multirow[b]{2}{*}{ MAFS } & \multirow[b]{2}{*}{$M L a^{a}$} & \multirow[b]{2}{*}{$\mathrm{MST}^{\mathrm{a}}$} \\
\hline & $\overline{\mathrm{APe}}$ & VEA & $\mathrm{LCi}$ & Rep & $\mathrm{HPa}$ & & & $\overline{\mathrm{CRe}}$ & $\mathrm{MPr}$ & Sel & & & \\
\hline \multicolumn{14}{|l|}{ Medicinal } \\
\hline Amai & 3.5 & 1.5 & 2 & 2 & 5 & 3.5 & 2 & 1 & $1,2,3,5,6$ & 1 & 0.37 & & $1,2,3$ \\
\hline Apsi & 3 & 2 & 2 & 1 & 5 & 3 & 2 & 1 & $1,2,3$ & 1 & 0.07 & & 1,2 \\
\hline Bsal & 1 & 1 & 2 & 2 & $1,1,3,5$ & 5 & 1 & 0 & $1,3,5,6$ & 0 & 1.04 & & 2 \\
\hline Clme & 2.5 & 1.5 & 2 & 1 & 5 & 4 & 2 & 1 & 2,5 & 1 & 0.60 & & 1,2 \\
\hline Cmex & 4 & 2 & 2 & 2 & 5,10 & 3 & 2 & 1 & 1,2 & 1 & 0 & & 1 \\
\hline Dcar & 3 & 2 & 2 & 2 & 4 & 4 & 2 & 0 & 1,3 & 1 & 0.07 & & 1,2 \\
\hline Gglu & 2 & 1 & 2 & 2 & 5 & 4 & 2 & 0 & 1,3 & 0 & 1.94 & & 1,2 \\
\hline Ginu & 2 & 2 & 2 & 2 & 5,10 & 4 & 2 & 1 & $2,4,5,6$ & 0 & 0.30 & & $1,2,3$ \\
\hline Loax & 2.5 & 2.5 & 2 & 2 & 4,5 & 3 & 2 & 1 & 1,2 & 1 & 0 & & 1 \\
\hline Mpar & 1 & 2 & 1 & 2 & 10 & 5 & 2 & 0 & $1,3,4$ & 1 & 0.72 & & 2 \\
\hline Mpur & 2 & 2 & 2 & 2 & 6,9 & 4 & 2 & 0 & 1,7 & 1 & 0.19 & & $1,2,3$ \\
\hline Mvul & 1 & 2 & 2 & 2 & 4 & 5 & 1 & 0 & 1,3 & 1 & 0.77 & & 2 \\
\hline Ppen & 1 & 1 & 2 & 2 & 10 & 5 & 2 & 0 & 3,5 & 0 & 0.25 & & 1,2 \\
\hline Pros & 1 & 1 & 2 & 2 & 3 & 4 & 2 & 0 & 1 & 1 & 0.67 & & 1,2 \\
\hline Rcom & 1 & 1 & 2 & 2 & 0,3 & 5 & 1 & 1 & $1,2,3,4,5,6$ & 1,2 & 0.43 & & 2 \\
\hline Spra & 4 & 0 & 2 & 2 & 2 & 3 & 1 & 0 & $1,3,5,6$ & 0 & 0.10 & & 1,3 \\
\hline Tdif & 2 & 0 & 2 & 2 & 5 & 2 & 2 & 0 & 1,2 & 0 & 0 & & 1 \\
\hline Tluc & 2.7 & 2 & 2 & 2 & 9 & 4 & 2 & 0 & 1,2 & 0 & 0 & & 1 \\
\hline Apot & 2 & 2 & 2 & 2 & $1,1,3,8,10$ & 2.8 & 1 & 1,2 & $1,3,4,5,6,7$ & 1 & 1.16 & & $1,2,3,4$ \\
\hline Qacu & 2 & 0 & 2 & 2 & $1,5,6,7,9$ & 4 & 2 & $1,2,3$ & $2,5,6,7$ & 1 & 0.03 & & 1,3 \\
\hline
\end{tabular}

ID identification tag assigned to the species analyzed (check Table 3 to identify the species), APe abundance perception, VEA vulnerability to environmental factors, $L C i$ life cycle, Rep reproduction, $H P a$ harvested part, Nea nearness to harvest site, TAv temporal availability, CRe collective regulations, MPr management practices type, Sel artificial selection, MAFS management in AFS, PrN practice number, MLa maintaining labors, MST management system type

${ }^{a}$ Excluded variables and species in the performance of principal component analyses (PCA) and canonical correspondence analyses

homegardens as it was documented for P. philadelphica (Table 6). Most species are considered vulnerable to environmental factors and pests (Table 7), and some of the most appreciated resources are perceived to be scarce. This is the case of $D$. serratifolium, which due to the scarcity of its inflorescences people stopped consuming them (Table 6).

Gathering of edible plants is generally carried out while practicing other activities-by men when plants are gathered from the forest and by women and children when plants are harvested from agricultural fields and homegardens. Gathering is the only practice for 30 species, which are immediately consumed (Table 3 ). Practices of care during gathering of useful parts aim to procuring plant survival, and these are carried out only in gathered plants and those under management (Tables 6 and 7). In order to ensure further availability, the abundance of seven species is enhanced by letting individual plants produce seeds and deliberately dispersing their seeds in appropriate places (Tables 3 and 7). At least 40 species are let standing in AFS, with the purpose of ensuring their availability (Tables 3, 6, and 7). For ensuring productivity and quality of products for consumption, 28 species receive irrigation, addition of organic matter, and exclusion from domestic animals (Tables 3 and 7). Nearly 20 species of weedy plants (among them P. philadelphica and D. ambrosioides) are transplanted into homegardens where people consider the plants to have better conditions for growing (Table 3). Other species occurring in the wild are transplanted to homegardens with the purpose of having them closer and to consume them for longer time (Porophyllum spp.) or for ornamental purposes (Mammillaria spp. and Lantana spp.) (Fig. 2, Tables 3 and 7). We recorded the deliberate propagation of 11 species through seeds and vegetative parts (Tables 3 and 6), as food (Porophyllum spp., D. ambrosioides, P. philadelphica, Opuntia spp.), for ornamental purposes, and for satisfying curiosity (Oxalis aff. nelsoni). Other species have started to be propagated, as is the case of $A$. potatorum, and others have had failed attempts (L.glaucescens, C. mexicana).

From seven species whose varieties are distinguished by morphology, flavor, and odor, we identified human selection in five of them; the preferred variants are tolerated, protected, or enhanced. For D. ambrosioides, 
O. lasiacantha, and P. philadelphica, we documented human selection favoring plants providing seeds or cladodes for cultivation (Tables 6 and 7).

Local customs and regulations forbid gathering wild edible plants for commercializing them out of the village, with the only exception of Brahea dulcis and $A$. potatorum, which are edible, but parts commercialized are destined for other uses. In the Communitarian Assemblies, we recorded discussions among local people and the Biosphere Reserve authorities for regulating and planning the use of $A$. potatorum, B. dulcis, and $D$. serratifolium. In the case of L. glaucescens, the Assembly decided to allow external people to extract it, but the permit stopped.

\section{Medicinal plants}

We recorded 219 medicinal plant species, 178 of them being native and naturalized, and 22 considered "basic plants" (Tables 3 and 4). Currently, 85\% of households use medicinal plants, generally complementing their healing treatment with massages, cupping therapy, and treatments by the national system of health through the local health center and private physicians. Women heads of families mainly make the decision on the appropriate treatment, while for traditional treatments, it is common to consult the relatives with more experience or one of the four traditional physicians in the village. The native plant species are mainly used for attending accidents (hurts, cuttings, twists, fractures, bites of poisonous animals), respiratory and stomach infections, pains, child tantrums, angers, "susto" (frightens), illnesses caused by "aires," monitoring of pregnancy, and recovering of childbirth. Medicinal plants may be ingested and placed in affected body zones, steam baths, and "limpias" (ceremonies for cleaning the body and spirit).

Almost all medicinal plants are collected when they are needed, but for some of them (Lippia oaxacana, T. lucida, T. diffusa, Chrysactinia mexicana, Ambrosia psilostachya), people used to store dry materials or ask somebody else to get the needed plant (Fig. 2, Table 5).

No commercialization of medicinal plants was recorded; most medicinal plants are shared. Some plants are interchanged for plants with other uses, for instance, Quercus acutifolia, used and commercialized as fuelwood, and $A$. potatorum used in mescal production (Table 5). Except $C$. mexicana and Pittocaulon praecox, all medicinal plants are considered abundant, but dryness and frosts are factors affecting their availability (Table 7).

Gathering of wild medicinal plants is conducted by men and women; men gather plants occurring far away and women those occurring in homegardens. Gathering is the most common practice for all medicinal plants, and the only practice for 81 species (Tables 3 and 4). Practices for preventing damage of gathered plants are common on the most valuable plants (Ambrosia psilostachya, Clinopodium mexicanum, $C$. mexicana, $L$. oaxacana, T. diffusa, T. lucida, Ageratina mairetiana, Grindelia inuloides) (Table 7, Fig. 2). In AFS, 79 medicinal plants are let standing during vegetation clearing, as well as the 65 species distributed in homegardens (Table 3). Among them, Ricinus communis, Marrubium vulgare, and Malva parviflora are submitted to practices for controlling their abundance through weeding, similarly to 37 other species (Table 1 ). We recorded 31 species receiving care such as removal of competitors, addition of organic matter, and irrigation (Table 3). Abundance of nine species is enhanced by leaving plants to produce seeds or by spreading the seeds in appropriate sites for their germination and growth (Tables 6 and 7). We also documented the transplanting of 25 species, 8 of them from forests to homegardens ( $G$. inuloides, $P$. praecox, and A. mairetiana) for their medicinal and ornamental uses (Tables 3 and 7). In addition, we recorded the propagation by seeds of 12 species, 2 of them mainly motivated to have them available when needed (G. inuloides and Matelea purpusii) (Fig. 2, Tables 3, 6, and 7). We documented failed attempts of transplanting and propagating six species, among them A. mairetiana, A. psilostachya, G. inuloides, and L. oaxacana (Table 6). Reasons for not transplanting individual plants from forests to homegardens were the following: lack of information about plant requirements and the supposition or experience that in changing habitat, plants do not survive and that using appropriate techniques of extraction or storing strategies are enough for ensuring their availability (Table 6). We recorded the recognition of varieties of three species, but people make differential use and management only of $R$. communis (Fig. 2, Table 7).

\section{Management intensity and risk}

Management intensity of edible, ceremonial, and medicinal plants studied is explained mainly by practices and communitarian regulations in the first component and by their presence in AFS in the second component (Fig. 3). Management intensity among use types was significantly different (KW $X^{2}=9.9, \mathrm{df}=2, p=0.007$ ). Edible plants had the highest management intensity, most of them managed in AFS involving human selection, while most species used for ceremonial and medicinal purposes are gathered from forests and protected through communitarian regulations (Fig. 3).

In plants with ceremonial use, the regression analysis indicates no relation among management intensity and risk indexes $\left(R^{2}=0.003, p=0.819\right)$ (Fig. 4, Table 8). Partial CCA explains $95 \%$ of the variation of management, significantly explained by the intersection of sociocultural and ecological factors (14\%) (Fig. 5a, Table 9). In plants 


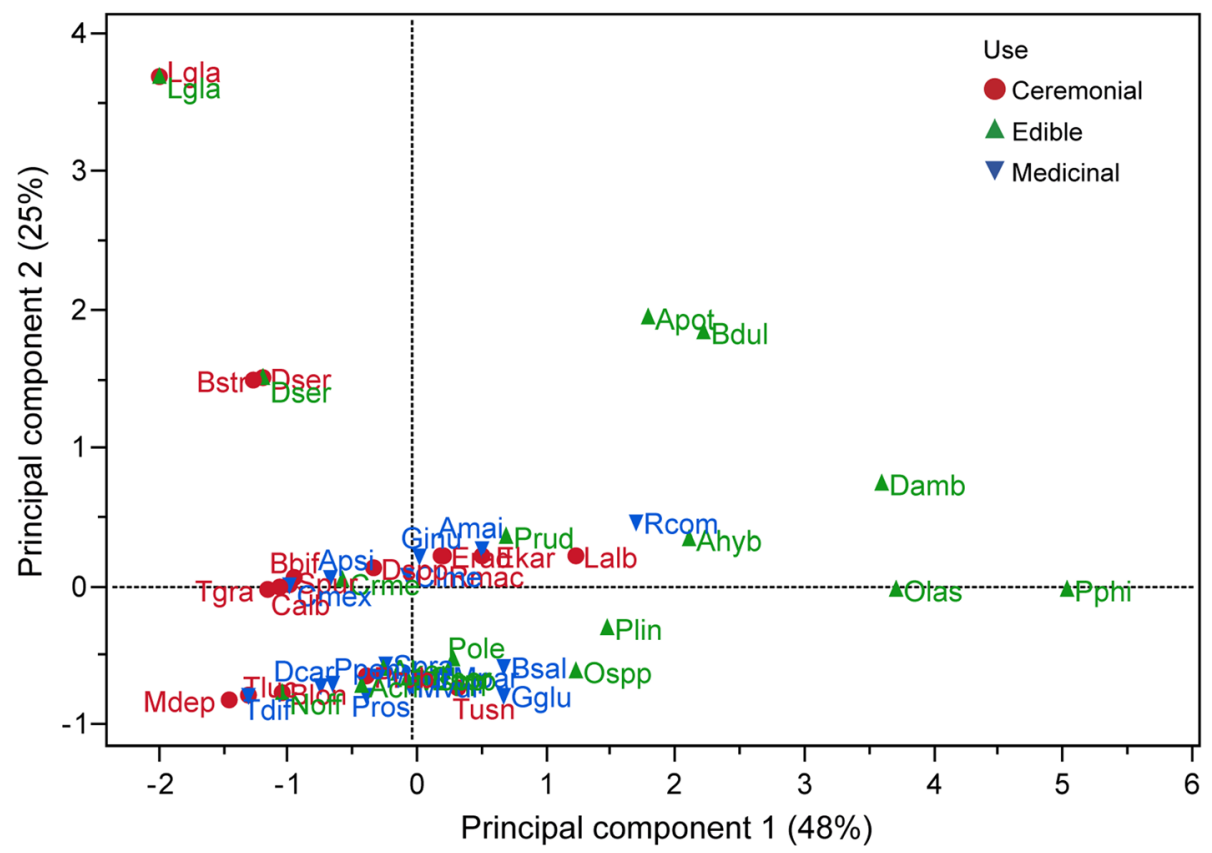

Fig. 3 Management of ceremonial, edible, and medicinal plants according to principal component analysis (PCA). Edible plants tended to be managed most intensely, since ceremonial and medicinal plants are less intensely managed. Variation in spatial arrangement is mainly explained in the first principal component by management practices and collective regulations $=$ (eigenvalues $0.631,-0.133$ respectively) and by collective regulations and management in AFS in the second principal component (eigenvalues $0.986,-0.007$ respectively)

with intermediate management intensity (Table 8), management regulated by collective rules occurs in plants basic for life and exclusively with sexual reproduction. These are the cases of L. glaucescens, D. serratifolium, B. stricta, and T. grandis (Fig. 5b, Table 9). Plants intensively managed (Table 8 ) in AFS are those providing several parts or the whole plant as resources, having asexual reproduction, and being abundant, like Tillandsia usneoides, or that are scarce, like Laelia albida, Euchile karwinskii, Epidendrum radioferens, and Rhynchostele maculata (Fig. 5b, Table 9).

In edible plants, the regression analysis indicates that there is a highly significant relation among management intensity and risk indexes $\left(R^{2}=0.48, p=0.0007\right.$ ) (Fig. 4, Table 8). Partial CCA explained $92 \%$ of the variation of management, significantly explained by sociocultural factors $(60 \%)$ and the intersection of sociocultural and ecological factors (14\%) (Fig. 5c, Table 9). Plants with the
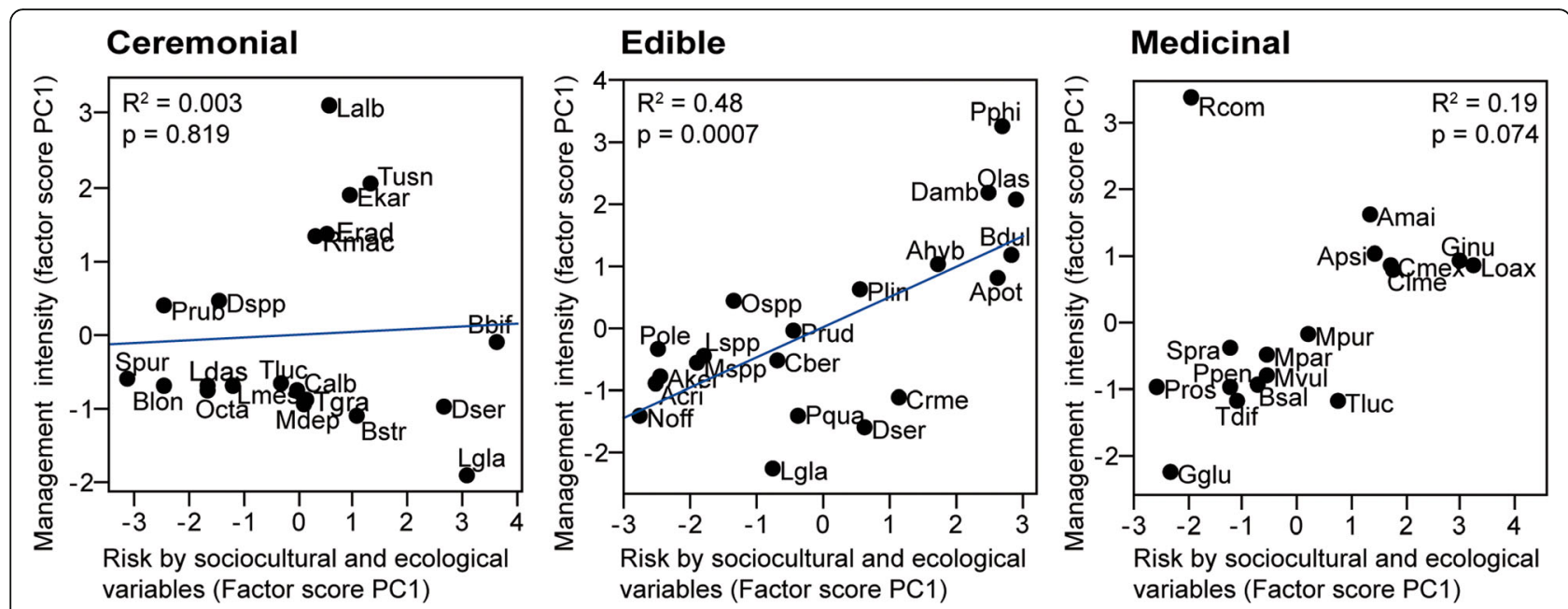

Fig. 4 Relation between management intensity and risk. Regression analysis of the management intensity index as a function of the risk index due to sociocultural and ecological factors. Indexes were calculated as the scores of the first principal components performed by use type 
Table 8 Management intensity and risk indexes of ceremonial, edible, and medicinal plants

\begin{tabular}{|c|c|c|c|c|c|c|c|c|}
\hline \multicolumn{3}{|c|}{ Ceremonial } & \multicolumn{3}{|l|}{ Edible } & \multicolumn{3}{|c|}{ Medicinal } \\
\hline ID & Management intensity index & Risk index & $\mathrm{ID}$ & Management intensity index & Risk index & $\mathrm{ID}$ & Management intensity index & Risk index \\
\hline Bbif & 0.12 & 0.62 & Acri & 0.13 & 0.27 & Amai & 0.29 & 0.47 \\
\hline Blon & 0.05 & 0.28 & Ahyb & 0.47 & 0.54 & Apsi & 0.15 & 0.37 \\
\hline Bstr & 0.19 & 0.47 & Aker & 0.14 & 0.27 & Bsal & 0.27 & 0.38 \\
\hline Calb & 0.10 & 0.43 & Apot & 0.55 & 0.62 & Clme & 0.22 & 0.38 \\
\hline Dser & 0.19 & 0.53 & Bdul & 0.61 & 0.57 & Cmex & 0.11 & 0.46 \\
\hline Dspp & 0.19 & 0.32 & Cber & 0.18 & 0.41 & Dcar & 0.09 & 0.33 \\
\hline Ekar & 0.29 & 0.42 & Crme & 0.15 & 0.57 & Gglu & 0.28 & 0.28 \\
\hline Erad & 0.25 & 0.38 & Damb & 0.62 & 0.59 & Ginu & 0.24 & 0.43 \\
\hline Lalb & 0.38 & 0.43 & Dser & 0.19 & 0.56 & Loax & 0.11 & 0.46 \\
\hline Ldas & 0.05 & 0.39 & Lgla & 0.27 & 0.40 & Mpar & 0.21 & 0.33 \\
\hline Lgla & 0.27 & 0.49 & Lspp & 0.20 & 0.35 & Mpur & 0.14 & 0.39 \\
\hline Lmes & 0.05 & 0.35 & Mspp & 0.18 & 0.31 & Mvul & 0.17 & 0.33 \\
\hline Mdep & 0.01 & 0.37 & Noff & 0.05 & 0.31 & Ppen & 0.11 & 0.31 \\
\hline Octa & 0.10 & 0.36 & Olas & 0.58 & 0.61 & Pros & 0.13 & 0.25 \\
\hline Prub & 0.13 & 0.34 & Ospp & 0.33 & 0.35 & Rcom & 0.41 & 0.41 \\
\hline Rmac & 0.25 & 0.39 & Plin & 0.35 & 0.45 & Spra & 0.15 & 0.35 \\
\hline Spur & 0.11 & 0.34 & Pole & 0.21 & 0.28 & Tdif & 0.03 & 0.33 \\
\hline Tgra & 0.09 & 0.49 & Pphi & 0.75 & 0.62 & Tluc & 0.03 & 0.43 \\
\hline Tusn & 0.23 & 0.36 & Pqua & 0.05 & 0.45 & & & \\
\hline Tluc & 0.03 & 0.37 & Prud & 0.31 & 0.42 & & & \\
\hline
\end{tabular}

Indexes were calculated based on the score of the first principal component of PCA performed by use type and variable kind, management variables for the management intensity index, and sociocultural and ecological variables for the risk index

ID identification tag assigned to the species analyzed; check Table 3 to identify the species

lowest management intensity (Table 8 ) are those protected through collective regulations, like $D$. serratifolium and $L$. glaucescens, which are shared among relatives and used in communitarian ceremonies, as well as in those gathered and perceived to be scarce, like $N$. officinale, $P$. quadrifolia, and C. mexicana (Fig. 5d, Table 9). Plants with the highest management intensity like $P$. philadelphica, $O$. lasiacantha, A. hybridus, and D. ambrosioides (Table 8) are those with different varieties, under human selection through several types of practices, considered to be abundant, shared among members of the community, and obtained through different strategies, among them interchange and commercialization (Fig. 5d, Table 9).

In medicinal plants, the regression analysis indicates no significant relation among management intensity and risk $\left(R^{2}=0.19, p=0.074\right)$ (Fig. 4, Table 8). Partial CCA explains $79 \%$ of the variation of management, mainly by sociocultural factors (46\%) (Fig. 5e, Table 9). Plants with low risk like Pinaropappus roseus and Gymnosperma glutinosum are directly consumed by people who gather them and, along with Marrubium vulgare, occur in most of the homegardens and crop fields sampled. These plants are only gathered and let standing (Fig. 5e, Table 9). Management through collective regulations determining care during gathering was documented on C. mexicana, L. oaxacana, and A. psilostachya, with relatively high management intensity and risk (Table 8) associated to their value in reciprocity, use frequency, strategies for obtaining them, and the perception of vulnerability to environmental factors (Fig. 5e, Table 9).

\section{Discussion \\ Management intensity}

As we hypothesized, the gradient of management intensity is higher in edible plants, which are managed through different types of practices in AFS, more frequently, and involving human selection. Contrarily, plants used for ceremonies and as medicine are mostly tolerated or simply gathered. These general trends are similar to other reports for edible plants studied in the region which are managed with more complex practices than other useful plant species [6, 22, 43-45].

Collective regulations importantly influence the management intensity, but differently to that proposed for a general model of management intensity [46], the highest complexity of such regulations was observed in plants that are only gathered in areas of common access, such as the most valuable medicinal and ceremonial plants. 

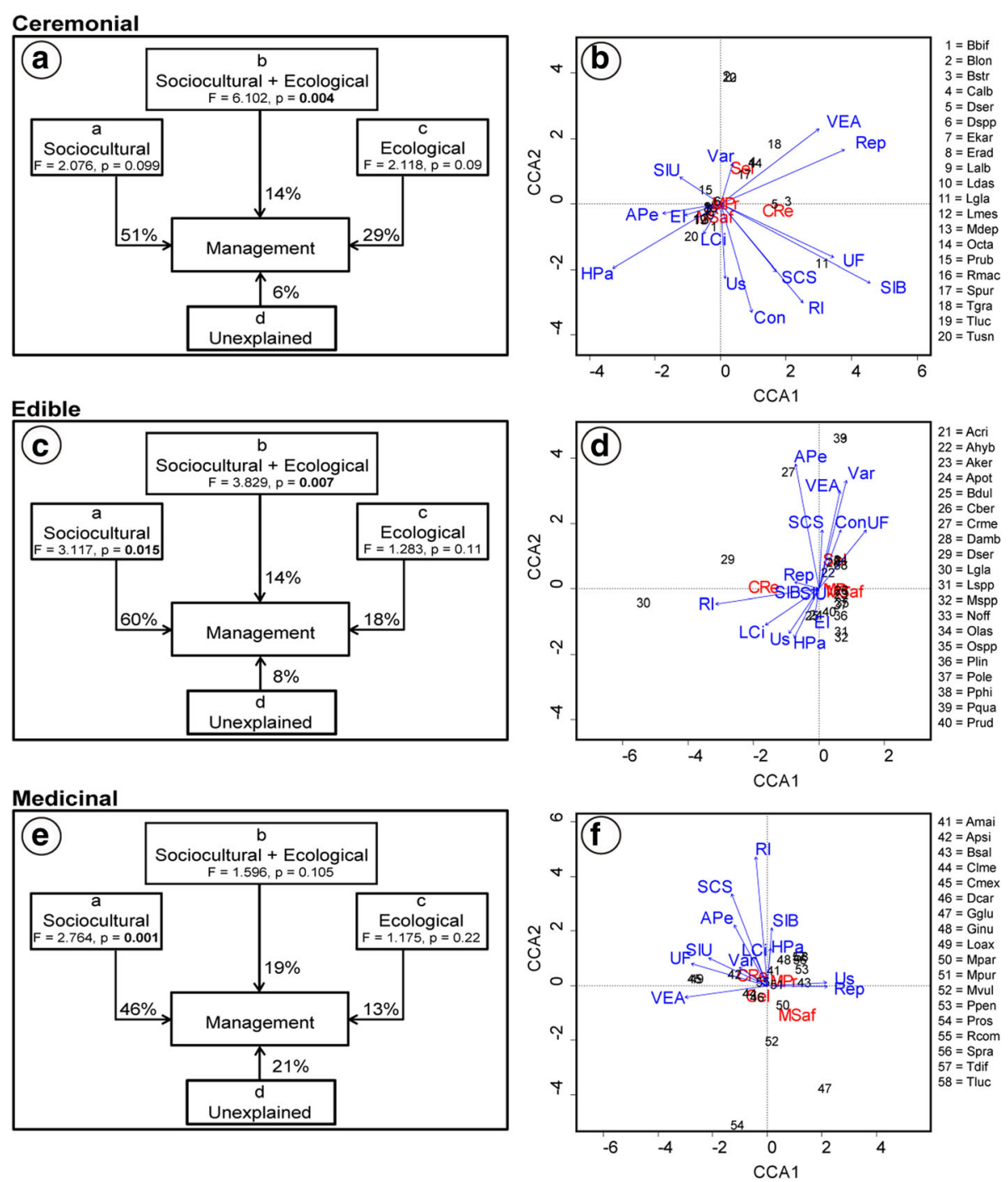

Fig. 5 a-f Relative influence of risk due to sociocultural and ecological factors in plant management. Schemes show the relative influence of sociocultural and ecological factors and their interactions on management of ceremonial, edible, and medicinal plants based on partitioned canonical correspondence analyses (CCA) performed by type use. Ordination planes of CCA performed by type use show how species (numbers) and management variables (red words) are influenced by sociocultural and ecological variables (blue arrows)

For the contrary, edible species are mainly managed in AFS, where managers have higher control of access to plant resources. These differences reflect the trade-offs in managing natural resources of common use, as it has been discussed previously for edible plants of the region and for several resources of common use [13, 47]. In the case studied, this pattern is illustrated by the fact that collective regulations appear to be effective for plants culturally valuable but not for plant resources with high economic value. The inefficacy of collective regulations for plants like A. potatorum appears to be due to the lack of rules coherent with the weakening of local institutions for ordering the use of a resource of increasing demand [28]. The failure of regulations for achieving a balance between cost and benefit of its management has enhanced private management in sites for exclusive use. But also, external actors have promoted the reforestation in areas of common use [16, 26], actions that should be accompanied by strengthening the effectiveness of local institutions.

The selective management characterizes the high management intensity in plants under the three types of use, according to flavors, colors, and sizes of plants or plant parts, which indicates ongoing processes of domestication, which may have advanced expressions like in $P$. philadelphica or, rather incipient, like in O. lasiacantha and $R$. communis $[5,15,48]$. The indistinct use of species with varieties recognized such as Chenopodium 
Table 9 Significance of explanatory variables on management associated with the canonical correspondence analyses (CCA) for ceremonial, edible, and medicinal plants

\begin{tabular}{|c|c|c|c|c|c|c|c|c|c|c|c|c|}
\hline \multirow[t]{2}{*}{ Risk variable } & \multicolumn{4}{|c|}{ Ceremonial } & \multicolumn{4}{|c|}{ Edible } & \multicolumn{4}{|c|}{ Medicinal } \\
\hline & $\overline{\mathrm{Df}}$ & $x^{2}$ & $F$ & $p$ & $\overline{\mathrm{Df}}$ & $x^{2}$ & $F$ & $p$ & $\overline{\mathrm{Df}}$ & $x^{2}$ & $F$ & $p$ \\
\hline \multicolumn{13}{|c|}{ Sociocultural and ecological variables } \\
\hline Uses number (Us) & 1 & 0.017 & 3.24 & 0.103 & 1 & 0.014 & 1.98 & 0.105 & 1 & 0.016 & 1.46 & 0.175 \\
\hline SI basic plants (SIB) & 1 & 0.190 & 35.41 & 0.002 & 1 & 0.008 & 1.09 & 0.219 & 1 & 0.021 & 1.84 & 0.11 \\
\hline SI by use type (SIU) & 1 & 0.003 & 0.47 & 0.695 & 1 & 0.003 & 0.45 & 0.497 & 1 & 0.026 & 2.33 & 0.09 \\
\hline Consumption (Con) & 1 & 0.029 & 5.35 & 0.024 & 1 & 0.013 & 1.80 & 0.125 & & & & \\
\hline Use frequency (UF) & 1 & 0.040 & 7.48 & 0.012 & 1 & 0.013 & 1.83 & 0.180 & 1 & 0.024 & 2.15 & 0.078 \\
\hline Economic interchange (El) & 1 & 0.010 & 1.85 & 0.22 & 1 & 0.006 & 0.79 & 0.389 & & & & \\
\hline Reciprocity interchange (RI) & 1 & 0.006 & 1.08 & 0.454 & 1 & 0.173 & 24.47 & 0.002 & 1 & 0.052 & 4.68 & 0.007 \\
\hline Recognized variants (Var) & 1 & 0.008 & 1.41 & 0.345 & 1 & 0.048 & 6.79 & 0.003 & 1 & 0.014 & 1.24 & 0.269 \\
\hline Sociocultural strategies (SCS) & 1 & 0.014 & 2.62 & 0.13 & 1 & 0.028 & 4.00 & 0.034 & 1 & 0.025 & 2.22 & 0.084 \\
\hline Abundance perception(Ape) & 1 & 0.026 & 4.88 & 0.045 & 1 & 0.027 & 3.76 & 0.035 & 1 & 0.011 & 1.01 & 0.398 \\
\hline Harvested parts ( $\mathrm{HPa}$ ) & 1 & 0.048 & 8.89 & 0.008 & 1 & 0.008 & 1.20 & 0.326 & 1 & 0.004 & 0.40 & 0.735 \\
\hline Life cycle (LCi) & 1 & 0.002 & 0.37 & 0.734 & 1 & 0.005 & 0.74 & 0.465 & 1 & 0.001 & 0.06 & 0.981 \\
\hline Reproduction (Rep) & 1 & 0.052 & 9.65 & 0.002 & 1 & 0.026 & 3.73 & 0.066 & 1 & 0.019 & 1.70 & 0.183 \\
\hline Vulnerability (VEA) & 1 & 0.015 & 2.72 & 0.111 & 1 & 0.007 & 0.97 & 0.416 & 1 & 0.001 & 0.06 & 0.967 \\
\hline Residual & 5 & 0.027 & & & 5 & 0.035 & & & 5 & 0.056 & & \\
\hline \multicolumn{13}{|l|}{ Sociocultural variables } \\
\hline Uses number (Us) & 1 & 0.017 & 1.028 & 0.352 & 1 & 0.014 & 1.29 & 0.114 & 1 & 0.016 & 1.77 & 0.106 \\
\hline SI basic plants (SIB) & 1 & 0.190 & 11.232 & 0.005 & 1 & 0.008 & 0.71 & 0.321 & 1 & 0.021 & 2.24 & 0.084 \\
\hline SI by use type (SIU) & 1 & 0.003 & 0.148 & 0.925 & 1 & 0.003 & 0.29 & 0.680 & 1 & 0.026 & 2.83 & 0.051 \\
\hline Consumption (Con) & 1 & 0.029 & 1.698 & 0.212 & 1 & 0.013 & 1.17 & 0.215 & & & & \\
\hline Use frequency (UF) & 1 & 0.040 & 2.374 & 0.131 & 1 & 0.013 & 1.19 & 0.217 & 1 & 0.024 & 2.61 & 0.037 \\
\hline Economic interchange (El) & 1 & 0.010 & 0.587 & 0.587 & 1 & 0.006 & 0.51 & 0.529 & & & & \\
\hline Reciprocity interchange (RI) & 1 & 0.006 & 0.343 & 0.808 & 1 & 0.173 & 15.89 & 0.001 & 1 & 0.052 & 5.68 & 0.001 \\
\hline Recognized variants (Var) & 1 & 0.008 & 0.447 & 0.687 & 1 & 0.048 & 4.41 & 0.029 & 1 & 0.014 & 1.51 & 0.189 \\
\hline Sociocultural strategies (SCS) & 1 & 0.014 & 0.832 & 0.487 & 1 & 0.028 & 2.60 & 0.099 & 1 & 0.025 & 2.70 & 0.048 \\
\hline Abundance perception(Ape) & 10 & 0.170 & & & 10 & 0.109 & & & 10 & 0.092 & & \\
\hline \multicolumn{13}{|l|}{ Ecological variables } \\
\hline Abundance perception(Ape) & 1 & 0.034 & 1.73 & 0.169 & 1 & 0.047 & 2.29 & 0.047 & 1 & 0.018 & 1.21 & 0.214 \\
\hline Harvested parts (HPa) & 1 & 0.089 & 4.51 & 0.023 & 1 & 0.011 & 0.55 & 0.443 & 1 & 0.010 & 0.64 & 0.509 \\
\hline Life cycle (LCi) & 1 & 0.001 & 0.05 & 0.983 & 1 & 0.024 & 1.18 & 0.196 & 1 & 0.002 & 0.14 & 0.953 \\
\hline Reproduction (Rep) & 1 & 0.033 & 1.68 & 0.221 & 1 & 0.045 & 2.19 & 0.075 & 1 & 0.017 & 1.12 & 0.274 \\
\hline Vulnerability (VEA) & 1 & 0.052 & 2.63 & 0.107 & 1 & 0.004 & 0.20 & 0.815 & 1 & 0.042 & 2.77 & 0.03 \\
\hline Residual & 14 & 0.277 & & & 14 & 0.284 & & & 12 & 0.181 & & \\
\hline
\end{tabular}

Number of permutations $=999 ; p$ values in italics are significant at 0.05

berlandieri suggests that there exists a process of decreasing of consumption and interest in human selection, differently to what is happening with $A$. potatorum, whose propagation starts with gathering seeds from several sites where agaves are recognized to have differential productivity. Such contrasting situations indicate the dynamic aspect of the processes of domestication, in which changes in values, the introduction of new food or products, and changes in markets, among other factors, have direct effects on management of plant resources.

\section{Sociocultural and ecological factors and management intensity}

As expected, management intensity in edible plants is associated with their high risk to disappear, compared to the pattern found in medicinal and ceremonial plants. 
However, in the analysis about how sociocultural and ecological factors influence on variation of management, we found a high variety of interactions. The economic value, which has been considered one of the most important factors motivating plant management $[12,13]$, was not significant in any of the systems studied. This result can be due to the low proportion of plant species that are interchanged through barter and commercialization, as well as the isolation of the community, a factor recognized to be significant for introducing non-timber forest products in markets [49]. Nevertheless, among the more intensely managed species, we recorded some whose management represents expenses ( $P$. philadelphica) or their commercialization represents main incomes for households (B. dulcis and A. potatorum), which indicates a relation between management intensity and the economic role of plants in subsistence [46].

Consumption was only significant in ceremonial plants, explaining the gradient of management intensity according to the feasibility of propagation, which may be difficult in plants highly used (Tillandsia grandis and Chiococca alba), compared with species lowly used but having vegetative propagation that makes easy their management (Plumeria rubra, Dahlia sp.).

The perception of abundance and its interaction with cultural value and management feasibility was a meaningful factor for explaining gradients of management intensity of ceremonial and edible plants. For instance, Peperomia quadrifolia, a highly valued species as food, is only gathered following the principle of leaving part of the plant in order that it continues propagating, since it is scarce, but it has very specific habitat requirements. Tillandsia usneoides is intensely managed in homegardens, although it is abundant in forests, since it is easily propagated; $P$. philadelphica, a basic species, is considered abundant because of the effect of intense management. The examples suggest that the balance between the invested effort in management and benefits obtained according to needs is an important factor for making decisions [50].

The interchange of plant species related to reciprocity was significant for explaining variation of management of edible and medicinal plants. In both use types, the interchanged plants are the most valuable species. In the case of edible plants, our analysis explained the variation in the extremes of the gradient of management intensity; plants of difficult access are managed by collective regulations, and those intensely managed are in AFS. Among the medicinal plants, our analysis identified those species managed following collective regulations and stored, but in the case of emergency, people practice interchange. Importance of this factor coincides with other reports analyzing management of AFS, where it has been found that the social relations of local people are a main factor influencing biodiversity in these systems since plant species are introduced to the systems and because numerous species are maintained to be shared $[44,51,52]$. The study of these relations is covering importance for understanding management of AFS. We suggest that these may be considered for understanding management of species, since these are expressions of affect, respect, and solidarity, through which people construct social nets of mutual support that are part of the cultural identity and strategies for facing risks in their subsistence [28, 53-55].

In edible and medicinal plants, the interest for obtaining resources through sociocultural strategies influences the management intensity. Strategies like mobility for increasing the harvesting area and gathering for storing, among other practices, may determine some degree of risk on plants, which are placed through collective regulations and management practices.

The cognitive prominence by use type may be an indicator of resource quality, but this was no significant factor in our analysis. The perception about the quality of resources arose as a factor related to the place where plants grow. This aspect enhances plant management in AFS [51, 53, 56], which was documented with $P$. philadelphica and O. lasiacantha. In wild plants, this perception influences the communitarian regulations, as was recorded for Bursera biflora, whose resin is naturally produced and is preferred over that produced after cutting the stem [57].

\section{Management motives}

Interactions between cultural importance, perception of scarcity, and feasibility of management suggest that several factors contribute to motivate management techniques, which was confirmed through the in-depth interviews qualitatively analyzed (Table 6). The worries expressed by people about the future availability of plants with ceremonial, edible, and medicinal uses suggest that uncertainty is a main motive determining management. Such worries can be explained because of the fact that in the analysis of cognitive prominence of plants considered as basic, people mentioned plants with the three uses, which means that they are considered indispensable elements of subsistence. This fact coincides with the general hypothesis of control of uncertainty as a main motive of management for ensuring resource availability [12]. However, the differences documented in types of management strategies and their intensity among use types may be due to the differential operation of other motives, as we hypothesized in this study.

Making easier the access to plants was an important motivation for transplanting or cultivating wild and weedy plants for the three use types analyzed. For edible and medicinal plants managed in homegardens, the main management motive is to have them close 
to home $[22,45,58,59]$. And this is why people transplant and propagate plants that are naturally abundant into other ecosystems (e.g., Porophyllum spp.), protect with different labors the maintenance of $D$. ambrosioides, or tolerate weedy and ruderal plants like Malva parviflora and Barkleyanthus salicifolius. In ceremonial plants, the need to have flowers easily accessible is also an important motive for transplanting and propagating plants (for instance orchids and Dahlia spp.), but this motive is associated with the purpose of embellishing an area (60\% of the ceremonial plant species are considered ornamental), a quality highly valued by the Ixcatec $[6,23,24,26,52,53,60]$.

The symbolic value associated with plants and animals has been proposed relevant for making management decisions $[8,61,62]$. It is particularly important in plants used for ceremonies, like B. biflora [21], L. glaucescens, Euchile karwinskii, and other orchids, and may influence the perception of importance of being careful during their gathering and as a motive for propagation.

Our study suggests that ethical principles are important for regulating use and management in order to prevent damage to plants (Table 6), recognizing them as living beings with "the right to exist." This is expressed in numerous tolerated plants with low cultural and economic value or even those without use [26]. Such criteria interact with others particularly in weedy and ruderal plants, with edible and/or medicinal uses such as A. hybridus, M. parvifolia, R. communis, and M. vulgare in which the perception of their potential as invasive plants determines a balance of efforts for maintaining and removing them $[23,26]$. Other motives identified in the maintenance of homegardens [59, 63, 64], such as experimental curiosity, were mentioned by people in order to develop continual innovation in management techniques.

This study aspires to contribute to understand the multifactorial influence of social and ecological aspects on decisions for managing plant resources $[26,65]$ with different purposes. It is clear from this and other studies that management of edible resources are mainly influenced by factors associated with availability of food or means for obtaining it, whereas medicinal plants, which are consumed less frequently, involve quality rather than quantity, and ritual plants involve symbolic aspects. The three groups of plants involve management, but the intensity required in each case varies. However, some plant resources are particularly valuable because of their multi-functionality [65]; these are species that in this study are called "basic" by local people and are outstandingly important resources receiving the greatest management intensity.

Ixcatlán is the only site in the world where the Ixcatec language is spoken, and only 15 persons speak this language. Our ethnobiological studies look for contributing to efforts of a linguistic group working in favor of conserving and recovering this language. Information recovered in this study includes audio and image systems that have helped to produce educative materials useful for teachers in schools for teaching the Ixcatec language. In addition, the information about resource use, and particularly about management techniques, are helpful for planning actions for ordination, conservation, and recovering forest areas and resources, as well as agroforestry systems, which are part of the biocultural heritage of the Ixcatec for the Ixcatec people, people of the Biosphere Reserve Tehuacán-Cuicatlán, and the Mexican people.

\section{Conclusions}

For managing edible, medicinal, and ceremonial plants, the Ixcatec have developed a broad variety of practices and regulations. Management strategies are motivated as responses to uncertainty in their availability and other motivations like embellishing an area, satisfying customs, emotions, and curiosity operating simultaneously in the decisions. Such a variety of factors is associated to a wellbeing premise combining both material and spiritual needs, as well as maintaining social relations and traditions that are part of the Ixcatec cultural identity [27, 50].

The highest management intensity in economic valuable species, mainly edible plants, indicates that uncertainty is significant in indispensable plants for satisfying subsistence needs. However, species of medicinal and ceremonial uses and some edible plants are managed through diverse management practices without response to abundance perception. These facts make necessary to analyze more deeply how needs, worries, external pressures, and management responses are articulated with subsistence strategies of households and communities in these processes, as well as the role of systems of ethical values and traditional regulation institutions.

Our study confirms the importance of sociocultural factors associated with use and interchange of resources, and ecological processes influencing the vulnerability and feasibility of managing them $[12,16,17]$. The multiple criteria may be useful to analyze conditions guiding early management motives that modeled the biocultural heritage of peoples of the Tehuacán Valley.

\section{Abbreviations \\ AFS: Agroforestry systems; CCA: Canonical correspondence analyses; PCA: Principal component analyses; TEK: Traditional ecological knowledge; UNAM: Universidad Nacional Autónoma de México}

\section{Acknowledgements}

We deeply thank the people of Santa María Ixcatlán and the authorities for their generosity and friendship. We also thank Erandi Rivera, Emanuel Emiliano González, and Ricardo Lemus for their collaboration in fieldwork and María Eugenia Salazar and Erandi Rivera for sharing panels $a, j, y$, and $k$ in Fig. 2. We thank the anonymous referees for their comments and suggestions that helped to improve this manuscript. 


\section{Funding}

The authors thank the Posgrado en Ciencias Biológicas at the Universidad Nacional Autónoma de México (UNAM) and the Consejo Nacional de Ciencia y Tecnología (CONACYT, Mexico) for supporting PhD studies and a grant for the first author. We also thank for the financial support for fieldwork the Red Temática: Productos Forestales No Maderables supported by CONACYT, CONACYT (Project CB-2013-01-221,800), the PAPIIT, UNAM (Research project IN209214), Fundación Alfredo Harp Helú Oaxaca, and Fundación UNAM (project IE-282.311.190).

\section{Availability of data and materials}

Data that support the analysis and additional data are provided in Tables 1 , 5 , and 7.

\section{Authors' contributions}

SRL is the main author, involved in the study design, field work, and analysis of the data; wrote the first draft; and concluded the final version of this paper. AC is main coordinator-supervisor of the research project, participated in data analyses, and reviewed several drafts of the manuscript. EGF and RL contributed to designing and following the progress of the research and reviewed the final drafts of the manuscript. All authors read and approved the final manuscript

\section{Authors' information}

SRL is a postgraduate student at the Instituto de Investigaciones en Ecosistemas y Sustentabilidad (IIES), UNAM. AC and EGF are full-time researchers at IIES, UNAM. RL is a full-time researcher at UBIPRO-FES Iztacala, UNAM.

\section{Ethics approval and consent to participate}

Permits for conducting our investigation were obtained from local authorities (municipal and land tenure), the Communitarian Assembly, and federal agencies (SEMARNAT and Tehuacán-Cuicatlán Biosphere Reserve-CONANP), to realize the investigation. Prior oral informed consent was obtained from all participants to realize the interview, survey, free lists, and visit and gather plants in their homegardens or agricultural fields. Reports of activities and preliminary investigation outcomes have been done via oral and written reports to the authorities and public presentations to the community of Ixcatlán.

\section{Consent for publication}

Not applicable.

\section{Competing interests}

The authors declare that they have no competing interests.

\section{Publisher's Note}

Springer Nature remains neutral with regard to jurisdictional claims in published maps and institutional affiliations.

\section{Author details}

${ }^{1}$ Instituto de Investigaciones en Ecosistemas y Sustentabilidad, UNAM Antigua Carretera a Pátzcuaro 8711, 58190 Morelia, Michoacán, Mexico. ${ }^{2}$ UBIPRO, Facultad de Estudios Superiores Iztacala, UNAM, Av. de los Barrios \#1, Los Reyes Ixtacala, Mexico, Mexico.

\section{Received: 31 July 2017 Accepted: 5 October 2017}

Published online: 30 October 2017

\section{References}

1. Toledo VM, Ortiz-Espejel B, Cortés L, Moguel P, de Ordoñez MJ. The multiple use of tropical forests by indigenous peoples in Mexico: a case of adaptive management. Conserv Ecol. 2003;7:9.

2. Boege E. El patrimonio biocultural de los pueblos indígenas de México. México, D. F.: Instituto Nacional de Antropología e Historia \& Comisión Nacional para el Desarrollo de los Pueblos Indígenas; 2008.

3. Maffi L. Linguistic, cultural, and biological diversity. Annu Rev Anthropol. 2005;34:599-617.

4. Casas A, Lira R, Torres I, Delgado A, Moreno-Calles Al, Rangel-Landa S, et al. Ethnobotany for sustainable ecosystem management: a regional perspective in the Tehuacán Valley. In: Lira R, Casas A, Blancas J, editors. Ethnobotany of Mexico: interactions of people and plants in Mesoamerica. New York: Springer; 2016. p. 179-206.
5. Casas A, Otero-Arnaiz A, Pérez-Negrón E, Valiente-Banuet A. In situ management and domestication of plants in Mesoamerica. Ann Bot. 2007;100:1101-15

6. Blancas J, Casas A, Rangel-Landa S, Moreno-Calles A, Torres I, Pérez-Negrón E, et al. Plant management in the Tehuacan-Cuicatlan Valley, Mexico. Econ Bot. Springer New York. 2010;64:287-302.

7. Berkes F, Colding J, Folke C. Rediscovery of traditional ecological knowledge as adaptive management. Ecol Appl. 2000;10:1251-62.

8. Toledo VM. Etnoecology: a conceptual framework for the study of indigenous knowledge of nature. In: Steep JR, editor. Ethnobiol. Cult. Divers. USA: International Society of Ethnobiology; 2002. p. 511-22.

9. Bye RA. The role of humans in the diversification of plants in Mexico. In: Ramamoorthy T, Bye RA, Lot A, Fa J, editors. Biol. Divers. Mex. Orig. Distrib. New York: Oxford University Press; 1993. p. 707-31.

10. Casas A, Parra F. La domesticación como proceso evolutivo. In: Casas A, Torres-Guevara J, Parra F, editors. Domest. en el Cont. Am. Vol. 1. Manejo Biodivers. y Evol. dirigida por las Cult. del Nuevo Mundo. Lima: UNALM \& UNAM; 2016. p. 133-58.

11. González-Insuasti MS, Caballero J. Managing plant resources: how intensive can it be? Hum Ecol. 2007;35:303-14.

12. Blancas J, Casas A, Pérez-Salicrup D, Caballero J, Vega E. Ecological and socio-cultural factors influencing plant management in Náhuatl communities of the Tehuacán Valley, Mexico. J Ethnobiol Ethnomed. 2013:9:39.

13. González-Insuasti MS, Martorell C, Caballero J. Factors that influence the intensity of non-agricultural management of plant resources. Agrofor Syst. 2008;74:1-15.

14. González-Insuasti MS, Casas A, Méndez-Ramírez I, Martorell C, Caballero J. Intra-cultural differences in the importance of plant resources and their impact on management intensification in the Tehuacán Valley, Mexico. Hum Ecol. 2011;39:191-202.

15. Arellanes Y, Casas A, Arellanes A, Vega E, Blancas J, Vallejo M, et al. Influence of traditional markets on plant management in the Tehuacán Valley. J Ethnobiol Ethnomed. 2013;9:38

16. Delgado-Lemus A, Torres I, Blancas J, Casas A. Vulnerability and risk management of Agave species in the Tehuacán Valley, México. J Ethnobiol Ethnomed. 2014;10:53.

17. Torres I, Blancas J, León A, Casas A. TEK, local perceptions of risk, and diversity of management practices of Agave inaequidens in Michoacán, Mexico. J Ethnobiol Ethnomed. 2015;11:1-20.

18. Casas A, Valiente-Banuet A, Viveros JL, Caballero J, Cortés L, Dávila P, et al. Plant resources of the Tehuacán-Cuicatlán Valley, Mexico. Econ Bot. 2001;55:129-66.

19. Casas A, Parra F, Blancas J, Rangel-Landa S, Vallejo-Ramos M, Figueredo CJ, et al. Origen de la domesticación y la agricultura: cómo y por qué. In: Casas A, Torres-Guevara J, Parra F, editors. Domest. en el Cont. Am. Vol. 1. Manejo Biodivers. y Evol. dirigida por las Cult. del Nuevo Mundo. Lima: UNALM \& UNAM; 2016. p. 189-224.

20. Ayma Al. Beneficios y maleficios de los árboles para los campesinos y su rol en el arreglo de sistemas agroforestales tradicionales en el Norte de Independencia, Bolivia. Acta Nov. 2011;5:225-46.

21. Berkes F. Sacred ecology. Second. New York: Routledge; 2008.

22. Blanckaert I, Swennen R, Paredes-Flores M, Rosas López R, Lira R. Floristic composition, plant uses and management practices in homegardens of San Rafael Coxcatlán, Valley of Tehuacán-Cuicatlán, Mexico. J Arid Environ. 2004:57:179-202.

23. Moreno-Calles A, Casas A, Blancas J, Torres I, Masera O, Caballero J, et al. Agroforestry systems and biodiversity conservation in arid zones: the case of the Tehuacán Valley, Central México. Agrofor Syst. 2010;80:315-31.

24. Vallejo M, Casas A, Blancas J, Moreno-Calles Al, Solís L, Rangel-Landa S, et al. Agroforestry systems in the highlands of the Tehuacán Valley, Mexico: indigenous cultures and biodiversity conservation. Agrofor Syst. 2014;88:125-40.

25. Vallejo M, Casas A, Pérez-Negrón E, Moreno-Calles Al, Hernández-Ordoñez O, Tellez $\mathrm{O}$, et al. Agroforestry systems of the lowland alluvial valleys of the Tehuacán-Cuicatlán Biosphere Reserve: an evaluation of their biocultural capacity. J Ethnobiol Ethnomed. 2015;11:8.

26. Rangel-Landa S, Casas A, Rivera-Lozoya E, Torres-García I, Vallejo-Ramos M xcatec ethnoecology: plant management and biocultural heritage in Oaxaca, Mexico. J Ethnobiol Ethnomed. 2016;12:30.

27. Casas A, Parra F, Torres-García I, Rangel-Landa S, Zarazúa M, Torres-Guevara J, Estudios y patrones continentales de domesticación y manejo de recursos 
genéticos: Perspectivas. In: Casas A, Torres-Guevara J, Parra F, editors. Domest. en el Cont. Am. Vol. 2. Investig. para el manejo sustentable Recur. genéticos en el Nuevo Mundo. Morelia: UNAM \& UNALM; 2017. p. 537-69.

28. CONABIO. Climas, Portal de Geoinformación, Sistema Nacional de Información sobre Biodiversidad. 2012. http://www.conabio.gob.mx/ informacion/gis/. Accessed Apr 2017. Comisión Nacional para el Conocimiento de la Biodiversidad.

29. Servicio Meteorológico Nacional. Normales climatológicas 1951-2010: Estación 00020129 Santa María Ixcatlán, Oaxaca. CONAGUA. 2010. http:// smn.cna.gob.mx/es/informacion-climatologica-ver-estado?estado=oax. Accessed Apr 2017.

30. Nava C, Romero M. Ixcatecos, pueblos indígenas del México contemporáneo. Comisión Nacional para el Desarrollo de los Pueblos Indígenas: México, D.F; 2007.

31. Instituto Nacional de Estadística y Geografía. Tabulados predefinidos, Oaxaca. In: Encuesta Intercensal; 2015. http://www.beta.inegi.org.mx/ proyectos/enchogares/especiales/intercensal/?init=1. Accessed Apr 2017.

32. Simons GF, Fennig CD, editors. Ethnologue: languages of the world, twentieth edition. Dallas: SIL International; 2017. Online version: http://www.ethnologue.com. Accessed Apr 2017

33. Valiente-Banuet A, Solís L, Dávila P, Arizmendi M del C, Silva C, Ortega-Ramírez J, et al. Guía de la vegetación del Valle de Tehuacán-Cuicatlán. México D.F: Universidad Nacional Autónoma de México, Comisión Nacional para el Conocimiento y Uso de la Biodiversidad, Instituto Nacional de Antropología e Historia, Universidad Autónoma de Tamaulipas \& Fundación para la Reserva de la Biosfera Tehuacán-Cuicatlán; 2009.

34. Diario Oficial de la Federación. Resolución sobre conflicto por límites de bienes comunales al poblado de Santa María Ixcatlán, municipio del mismo nombre, Estado de Oaxaca. 1948. http://www.dof.gob.mx/. Accessed 25 May 2015. México.

35. Hironymous MO. Santa María Ixcatlan, Oaxaca: from colonial cacicazgo to modern municipio. Ph.D. thesis. University of Texas at Austin; 2007.

36. Royal Botanic Gardens, Kew, Missouri Botanical Garden. The plant list. A working list of all plant species. http://www.theplantlist.org/. Accessed Apr 2017.

37. Nolan JM. Pursuing the fruits of knowledge: cognitive ethnobotany in Missouri's Little Dixie. J Ethnobiol Ethnomed. 2001;21:29-51.

38. Nolan JM, Robbins MC. Emotional meaning and the cognitive organization of ethnozoological domains. J Linguist Anthropol. 2001;11:240-9.

39. Sutrop U. List task and a cognitive salience index. Field Methods. 2001;13:263-76.

40. Pennec F, Wencelius J, Garine E, Raimond C, Bohbot HFLAME. v1.0: free-list analysis under Microsoft Excel. Paris: CNRS; 2012.

41. Borcard D, Legendre P, Drapeau P. Partialling out the spatial component of ecological variation. Ecology. 1992;73:1045-55.

42. R Core Team. R: a language and environment for statistical computing. Vienna: R foundation for statistical computing. 2016.

43. Lira R, Casas A, Rosas-López R, Paredes-Flores M, Pérez-Negrón E, Rangel-Landa S, et al. Traditional knowledge and useful plant richness in the Tehuacán-Cuicatlán Valley, Mexico. Econ Bot. 2009;63:271-87.

44. Moreno-Calles Al, Casas A, García-Frapolli E, Torres-García I. Traditional agroforestry systems of multi-crop "milpa" and "chichipera" cactus forest in the arid Tehuacán Valley, Mexico: their management and role in people's subsistence. Agrofor Syst. 2012;84:207-26.

45. Larios C, Casas A, Vallejo M, Moreno-Calles Al, Blancas J. Plant management and biodiversity conservation in Náhuatl homegardens of the Tehuacán Valley, Mexico. J Ethnobiol Ethnomed. 2013:9:74

46. Blancas J, Casas A, Moreno-Calles Al, Caballero J. Cultural motives of plant management and domestication. In: Lira R, Casas A, Blancas J, editors. Ethnobotany of Mexico: interactions of people and plants in Mesoamerica. New York: Springer; 2016. p. 233-55.

47. Ostrom E. Governing the commons: the evolution of institutions for collective action. 2nd ed. Cambridge: Cambridge University Press; 1990.

48. Casas A, Blancas J, Otero-Arnaiz A, Cruse-Sanders J, Lira R, Avendaño A, et al. Evolutionary ethnobotanical studies of incipient domestication of plants in Mesoamerica. In: Lira R, Casas A, Blancas J, editors. Ethnobotany of Mexico: interactions of people and plants in Mesoamerica. New York: Springer; 2016. p. 257-85.

49. Belcher B, Ruíz-Pérez M, Achdiawan R. Global patterns and trends in the use and management of commercial NTFPs: implications for livelihoods and conservation. World Dev. 2005;33:1435-52.

50. Alcorn JB. Factors influencing botanical resource perception among the Huastec: suggestions for future ethnobotanical inquiry. J Ethnobiol. 1981;1:221-30.
51. Ban N, Coomes OT. Home gardens in Amazonian Peru: diversity and exchange of planting material. Geogr Rev. 2004;94:348-67.

52. Aguilar-Støen M, Moe SR, Camargo-Ricalde SL. Home gardens sustain crop diversity and improve farm resilience in Candelaria Loxicha, Oaxaca, Mexico. Hum Ecol. 2009;37:55-77.

53. Calvet-Mir L, Gómez-Baggethun E, Reyes-García V. Beyond food production: ecosystem services provided by home gardens. A case study in Vall Fosca, Catalan Pyrenees, northeastern Spain. Ecol Econ. 2012;74:153-60.

54. Lope-Alzina DG. Una red comunal de acceso a alimentos: el huerto familiar como principal proveedor de productos para intercambio en una comunidad Maya-Yucateca. Gaia Sci. 2014;8:199-215.

55. Halstead P, O'Shea J, editors. Bad year economics: cultural responses to risk and uncertainty. Cambridge: Cambridge University Press; 1989.

56. Reyes-García V, Aceituno L, Vila S, Calvet-Mir L, Garnatje T, Jesch A, et al. Home gardens in three mountain regions of the Iberian Peninsula: description, motivation for gardening, and gross financial benefits. J Sustain Agric. 2012;36:249-70.

57. Purata SE. Uso y manejo de los copales aromáticos: aceites y resinas. México: CONABIO, RAISES; 2008

58. Tello-Villavicencio. Las plantas aromáticas en los Andes peruanos. In: Casas A, Torres-Guevara J, Parra F, editors. Domest. en el Cont. Am. Vol. 2. Investig. para el manejo sustentable Recur. genéticos en el Nuevo Mundo. Morelia: UNAM \& UNALM; 2017. p. 345-74.

59. Lope-Alzina DG, Howard PL. The structure, composition, and functions of homegardens: a focus on the Yucatan Peninsula. Etnoecológica. 2012;9:17-41.

60. Cook SF. Santa María Ixcatlán: habitat, population, subsistence. In: Sauer CO, Woodrow B, Cook SF, Rowe JH, editors. Ibero-Amer. Berkeley and LoS Angeles: University of California Press; 1958.

61. Atran S, Medin DL, Ross NO. The cultural mind: environmental decision making and cultural modeling within and across populations. Psychol Rev. 2005;112:744-76.

62. Salazar-Rojas VM, Herera-Cabrera BE, Flores-Palacios A, Ocampo-Fletes I. Traditional use and conservation of the "calaverita"; Laelia anceps subsp. dawsonii f. chilapensis Soto-Arenas at Chilapa Guerrero. Lankesteriana Int J Orchid. 2007:7:368-70.

63. Clayton S. Domesticated nature: motivations for gardening and perceptions of environmental impact. J Environ Psychol. 2007;27:215-24.

64. Bhatti M, Church A, Claremont A, Stenner P. "I love being in the garden": enchanting encounters in everyday life. Soc Cult Geogr. 2009;10:61-76.

65. Sõukand R, Hrynevich Y, Vasilyeva I, Prakofjewa J, Vnukovich Y, Paciupa J, Hlushko A, Knureva Y, Litvinava Y, Vyskvarka S, Silivonchyk H, Paulava A, Kõiva M, Kalle R. Multi-functionality of the few: current and past uses of wild plants for food and healing in Liubań region, Belarus. J Ethnobiol Ethnomed. 2017:13:10.

\section{Submit your next manuscript to BioMed Central and we will help you at every step:}

- We accept pre-submission inquiries

- Our selector tool helps you to find the most relevant journal

- We provide round the clock customer support

- Convenient online submission

- Thorough peer review

- Inclusion in PubMed and all major indexing services

- Maximum visibility for your research

Submit your manuscript at www.biomedcentral.com/submit 